\title{
Application of NMR Spectroscopy for the Detection of Equilibrating $E-Z$ Diastereomers
}

Syed Raziullah Hussaini, ${ }^{*},{ }^{\dagger}$ Adama Kuta,${ }^{\dagger}$ Arpan Pal,${ }^{\dagger}$ Zhiguo Wang, ${ }^{\dagger}$ Margaret A. Eastman,${ }^{\ddagger}$ and Ramon Duran $^{\dagger}$

'Department of Chemistry and Biochemistry, The University of Tulsa, 800 S. Tucker Drive, Oklahoma 74104, United States

Department of Chemistry, Oklahoma State University, Stillwater, Oklahoma 74074, United States

Email: syed-hussaini@utulsa.edu

Table of Contents

\begin{tabular}{|c|c|c|}
\hline 1. & Tabulated ${ }^{1} \mathrm{H}$ and ${ }^{13} \mathrm{C}$ chemical shift values of $\mathbf{5}$ and $\mathbf{5}$ & S2 \\
\hline 2. & ${ }^{1} \mathrm{H},{ }^{13} \mathrm{C}$ and DEPT NMR spectra of $\mathbf{5}$ and $\mathbf{5}$ & S3-S5 \\
\hline 3. & Chemical shift assignment of two aromatic rings of $\mathbf{5}$ and $\mathbf{5}$ & S6-S8 \\
\hline 4. & Confirmation of $E-Z$ isomerization of $\mathbf{5}$ and $\mathbf{5}$ & S9-S10 \\
\hline 5. & Other 1-D and 2-D NMR spectra of $\mathbf{5}$ and $\mathbf{5}$ & S11-S15 \\
\hline 6. & Tabulated ${ }^{1} \mathrm{H}$ and ${ }^{13} \mathrm{C}$ chemical shift values of 6 and $6{ }^{\prime}$ & S16 \\
\hline 7. & ${ }^{1} \mathrm{H}$ and ${ }^{13} \mathrm{C}$ NMR spectra of $\mathbf{6}$ and $6{ }^{\prime}$ & S17-S18 \\
\hline 8. & Other 1-D and 2-D NMR spectra of $\mathbf{6}$ and $\mathbf{6}$ & S19-S30 \\
\hline 9. & Tabulated ${ }^{1} \mathrm{H}$ chemical values of a mixture of cis and trans stilbene & S31 \\
\hline 10. & ${ }^{1} \mathrm{H}$ spectrum of a cis and trans stilbene mixture & S32 \\
\hline 11. & 1-D and 2-D NOESY spectra of a cis and trans stilbene mixture & S33-S34 \\
\hline 12. & Tabulated ${ }^{1} \mathrm{H}$ and ${ }^{13} \mathrm{C}$ chemical shift values of $\mathbf{7}$ and $\mathbf{7}^{\prime}$ & S35 \\
\hline 13. & ${ }^{1} \mathrm{H}$ and ${ }^{13} \mathrm{C}$ NMR spectra of 7 and 7 , & S36-S37 \\
\hline 15. & Confirmation of $E-Z$ isomerization of 7 and 7 & S38-S39 \\
\hline 16 & Other 1-D and 2-D NMR spectra of 7 and 7' & S40-S50 \\
\hline 18. & 1-D and 2-D NMR spectra of 8 & S51-S55 \\
\hline 19. & ${ }^{1} \mathrm{H}$ and ${ }^{13} \mathrm{C}$ NMR spectra of dibenzyl 2-diazomalonate (9) & S56-S57 \\
\hline 20. & References & S58 \\
\hline
\end{tabular}


Figure S1. (E/Z) Ethyl 3-(4-methoxyphenyl)-2-phenyl-3-(piperidin-1-yl)acrylate.
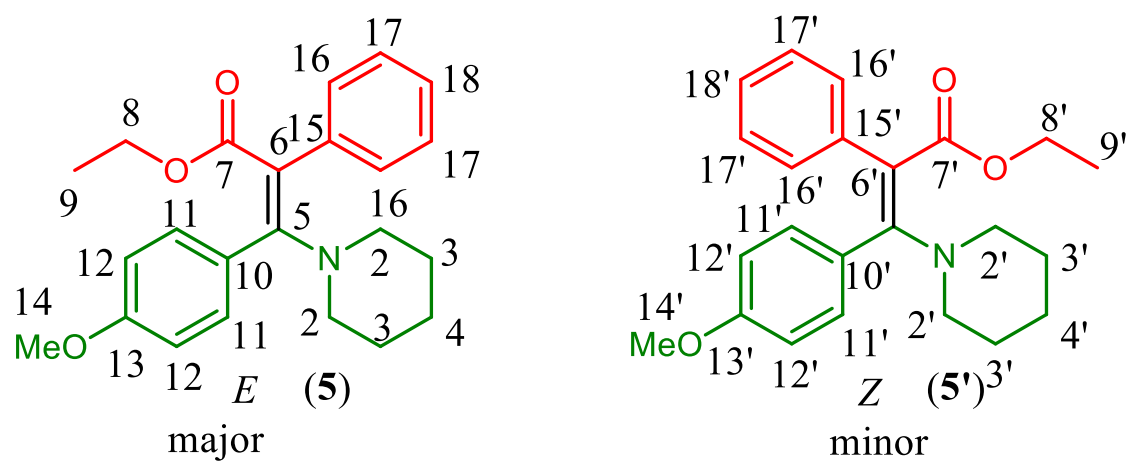

Table S1. In $\mathrm{CDCl}_{3}(E / Z$ 1.1:1)

\begin{tabular}{|c|c|c|c|c|c|}
\hline Position & $\begin{array}{c}\delta \mathrm{C} \\
\text { (major, 5) }\end{array}$ & $\begin{array}{c}\delta \mathrm{H} \text { (major, 5) } \\
J \text { in Hz }\end{array}$ & Position & $\delta \mathrm{C}$ (minor, 5') & $\begin{array}{c}\delta \text { H (minor, 5') } \\
J \text { in Hz }\end{array}$ \\
\hline 2 & 52.3 & $2.67-2.65, \mathrm{~m}$ & $2^{\prime}$ & 52.0 & $3.05, \mathrm{t}(5.2)$ \\
\hline 3 & 24.1 & $1.48, \mathrm{br} \mathrm{s}$ & $3^{\prime}$ & 24.4 & $1.71-1.64, \mathrm{~m}$ \\
\hline 4 & 26.9 & $1.48, \mathrm{br} \mathrm{s}$ & $4^{\prime}$ & 27.2 & $1.71-1.64, \mathrm{~m}$ \\
\hline 5 & 162.0 & & $5^{\prime}$ & 161.7 & \\
\hline 6 & 107.8 & & $6^{\prime}$ & 106.8 & \\
\hline 7 & 171.7 & & $7^{\prime}$ & 169.1 & \\
\hline 8 & 59.6 & $3.84, \mathrm{q}(7.2)$ & $8^{\prime}$ & 59.9 & $4.24, \mathrm{q}(7.2)$ \\
\hline 9 & 14.0 & $0.83, \mathrm{t}(7.2)$ & $9^{\prime}$ & 14.7 & $1.26, \mathrm{t}(7.2)$ \\
\hline 10 & 132.5 & & $10^{\prime}$ & 130.3 & \\
\hline 11 & 113.7 & $6.91, \mathrm{~d}(8.8)$ & $11^{\prime}$ & 113.3 & $6.67, \mathrm{~d}(9.2)$ \\
\hline 12 & 131.1 & $7.42, \mathrm{~d}(8.8)$ & $12^{\prime}$ & 133.1 & $7.21-7.19, \mathrm{~m}$ \\
\hline 13 & 160.9 & & $13^{\prime}$ & 160.2 & \\
\hline 14 & 55.4 & $3.85, \mathrm{~s}$ & $14^{\prime}$ & 55.2 & $3.72, \mathrm{~s}$ \\
\hline 15 & 140.5 & & $15^{\prime}$ & 140.8 & \\
\hline 16 & 130.9 & $7.12-7.10, \mathrm{~m}$ & $16^{\prime}$ & 131.9 & $6.92-6.90, \mathrm{~m}$ \\
\hline 17 & 128.0 & $7.35-7.30, \mathrm{~m}$ & $17^{\prime}$ & 127.3 & $7.02-6.98, \mathrm{~m}$ \\
\hline 18 & 125.4 & $7.17-7.14, \mathrm{~m}$ & $18^{\prime}$ & 124.4 & $6.92-6.90, \mathrm{~m}$ \\
\hline
\end{tabular}


Figure S2. ${ }^{1} \mathrm{H}$ NMR of the mixture of 5 and 5'

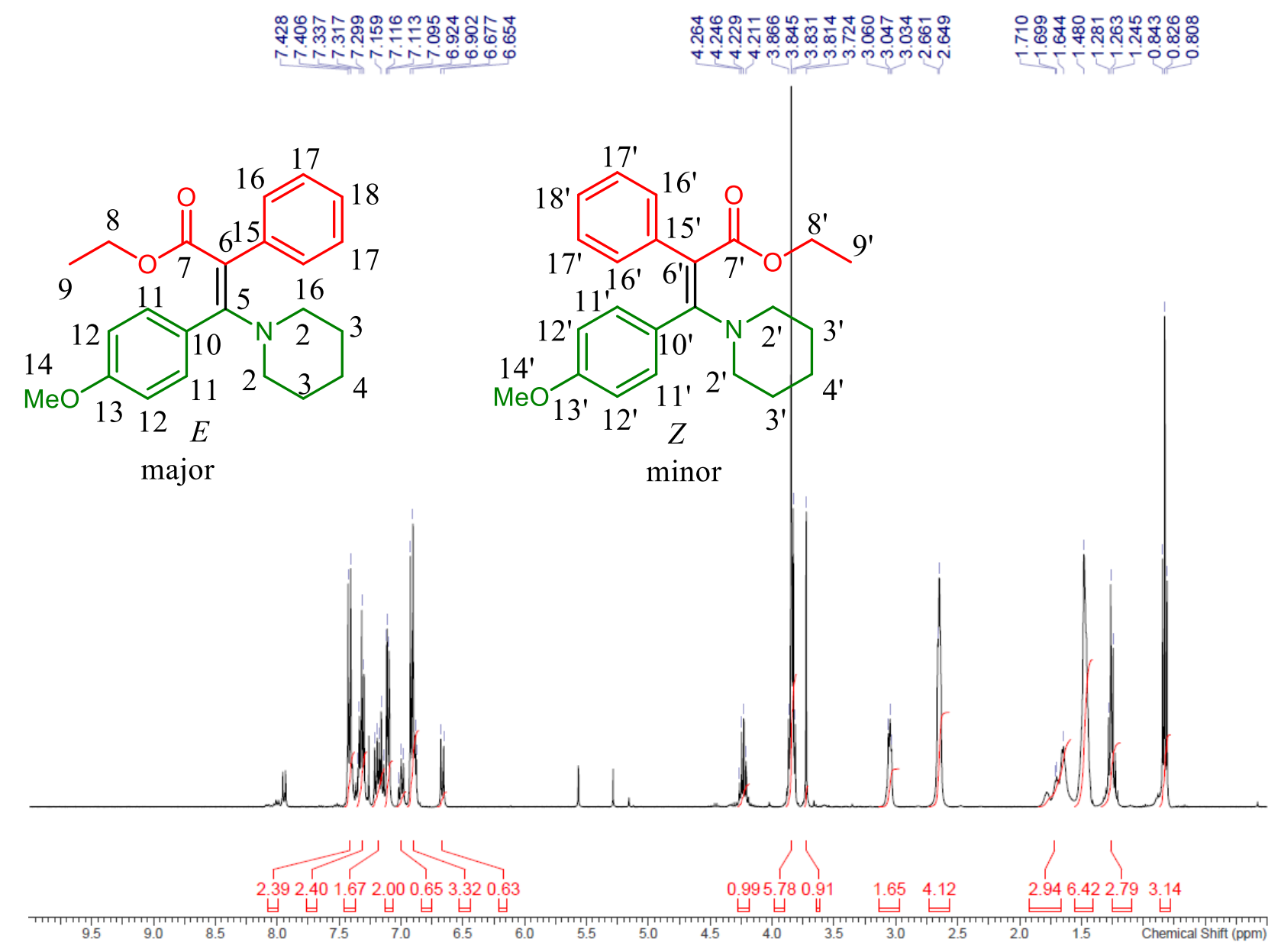


Figure S3. ${ }^{13} \mathrm{C}$ NMR of the mixture of 5 and 5',

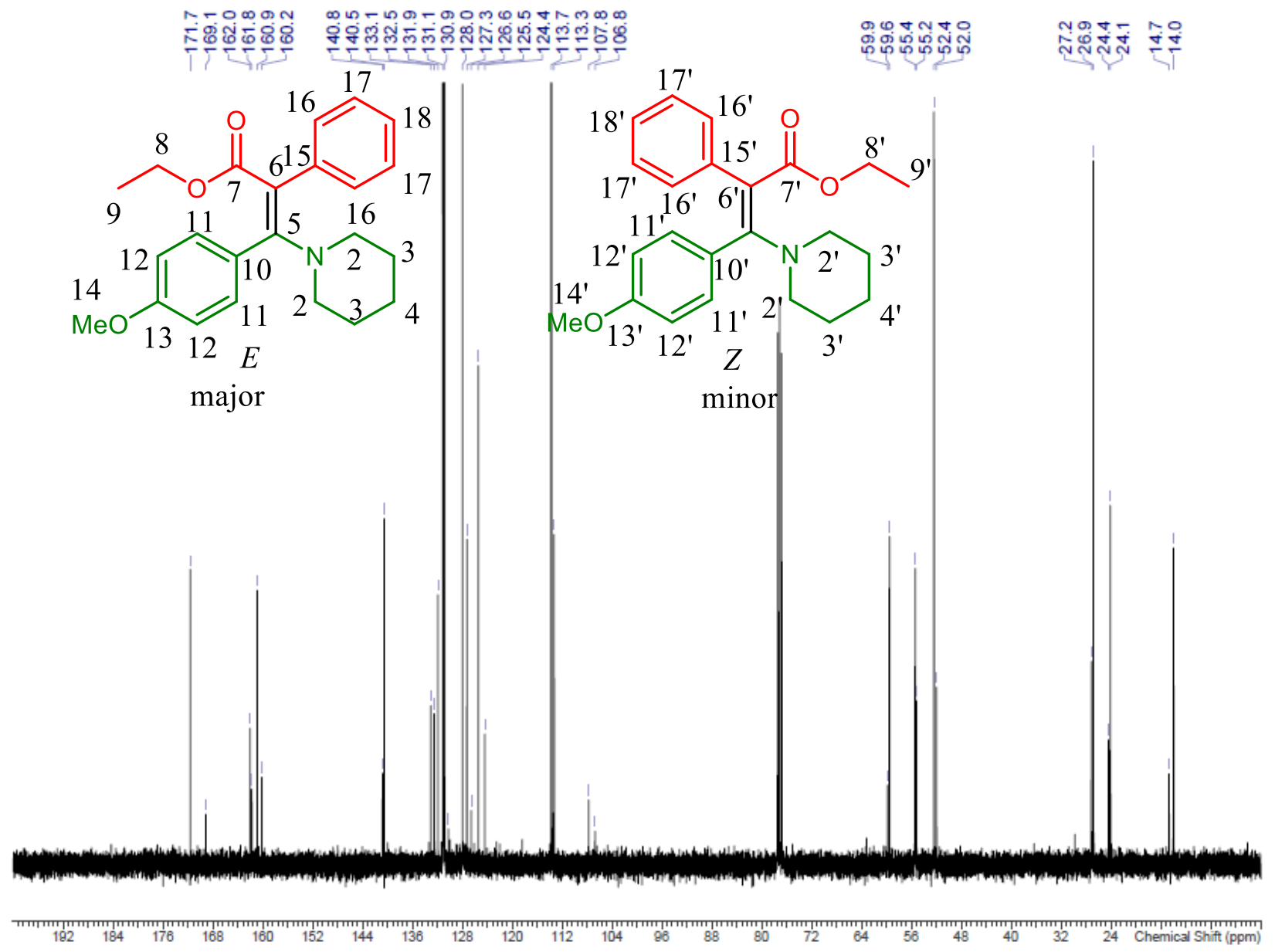


Figure S4. DEPT NMR of the mixture of 5 and 5',

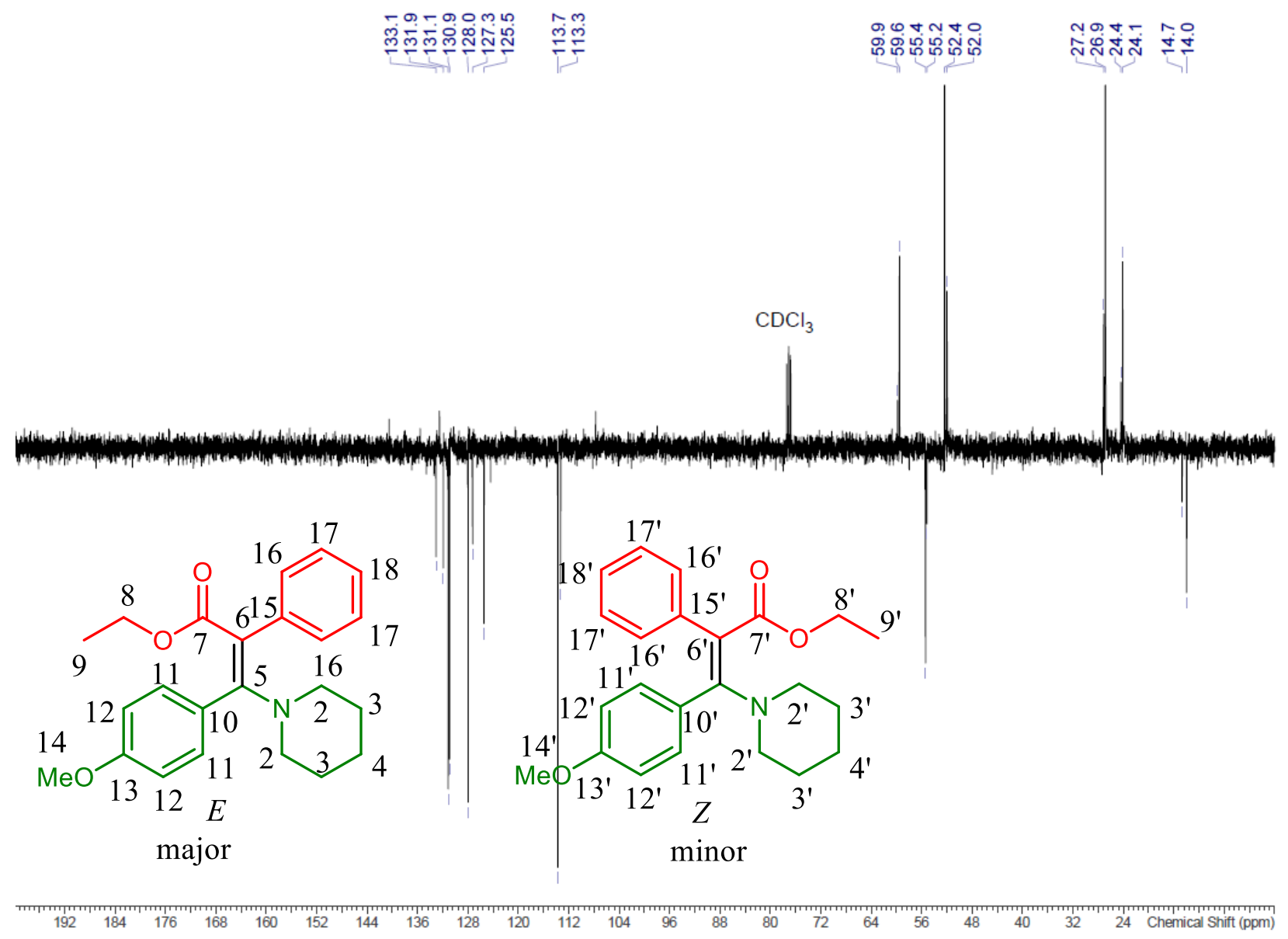




\section{Chemical shift assignment of two aromatic rings}

The two aromatic rings were differentiated using 2-D spectroscopy. Signal intensities in the ${ }^{1} \mathrm{H}-{ }^{13} \mathrm{C}$ HSQC correlations show that the ${ }^{1} \mathrm{H}$ peaks between 6.92-6.90 ppm belong to hydrogens that are attached to two carbon atoms of the minor and one carbon atom of the major isomer. This HSQC information was used to separate ${ }^{1} \mathrm{H}$ peaks of the $\mathrm{C}(11)$ hydrogens from $\mathrm{C}\left(17^{\prime}\right)$ and $\mathrm{C}\left(18^{\prime}\right)$ hydrogens. The HSQC spectrum also shows that the ${ }^{1} \mathrm{H}$ peaks between 7.21-7.14 ppm belong to one carbon of the major and one carbon of the minor isomer. This HSQC information was used to separate ${ }^{1} \mathrm{H}$ peaks of the $\mathrm{C}(18)$ hydrogen from $\mathrm{C}\left(12^{\prime}\right)$ hydrogens. The assignment was confirmed by ${ }^{1} \mathrm{H}-{ }^{1} \mathrm{H}$ COSY correlations and $\mathrm{HMBC}$ correlations.

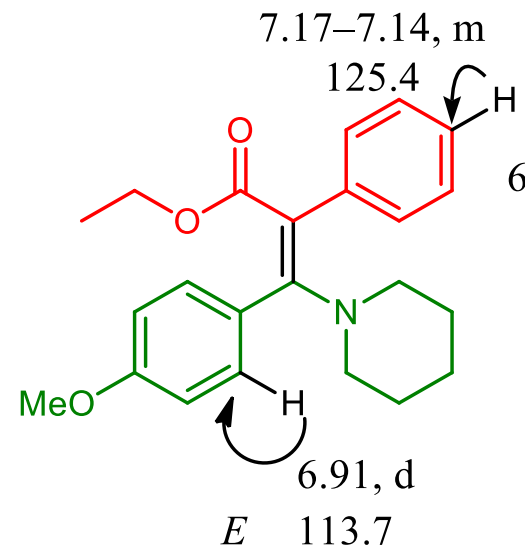

major
$6.92-6.90, \mathrm{~m}$ 124.4 $6.92-6.90, \mathrm{~m}$

131.9

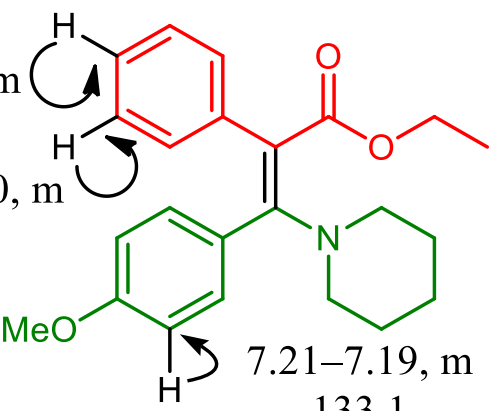

$Z$ 133.1

minor

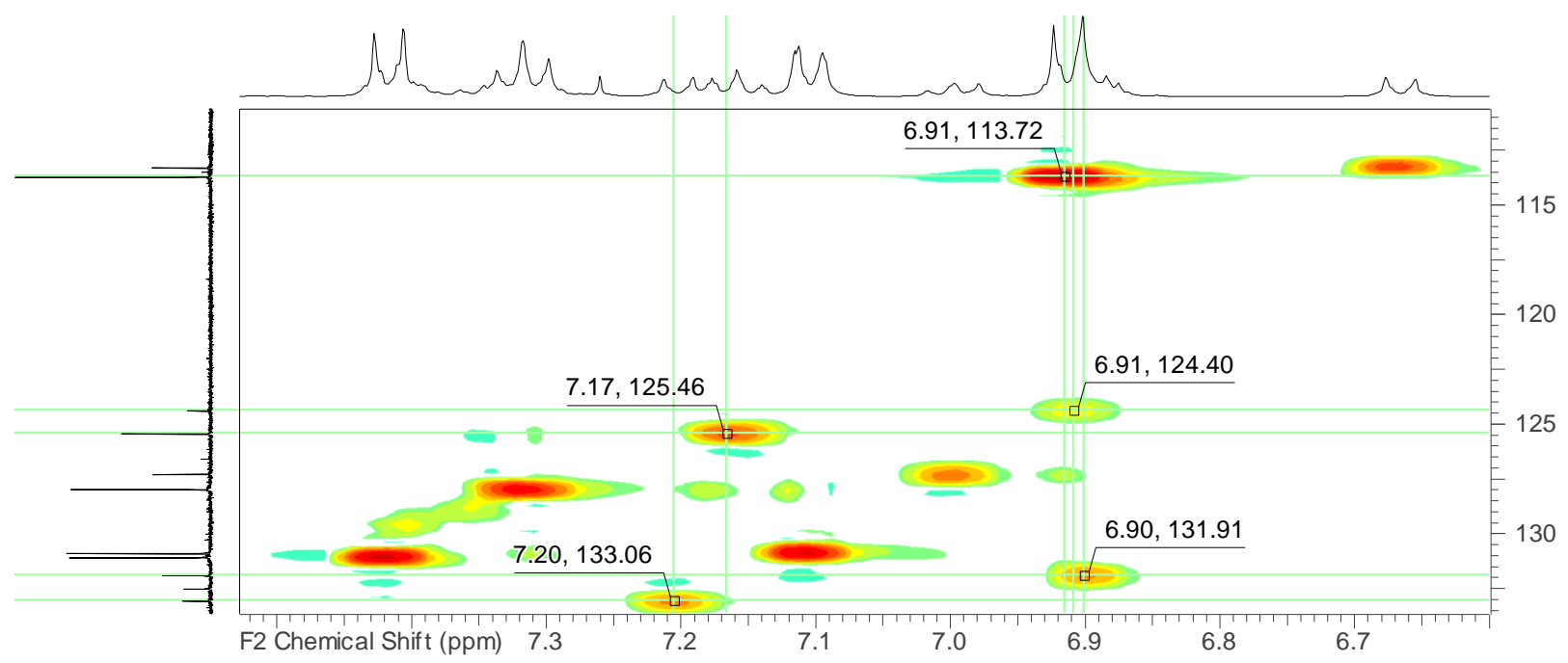

Figure S5. Key HSQC correlations showing overlapping ${ }^{1} \mathrm{H}$ signals. Structural drawings show ${ }^{1} \mathrm{H}-{ }^{13} \mathrm{C}$ correlations shown in the spectrum below the structures. For clarity only one of the two ortho and meta signals are shown in the structural drawings. 
Figure S6. Key ${ }^{1} \mathrm{H}-{ }^{1} \mathrm{H}$ COSY correlations are shown below.
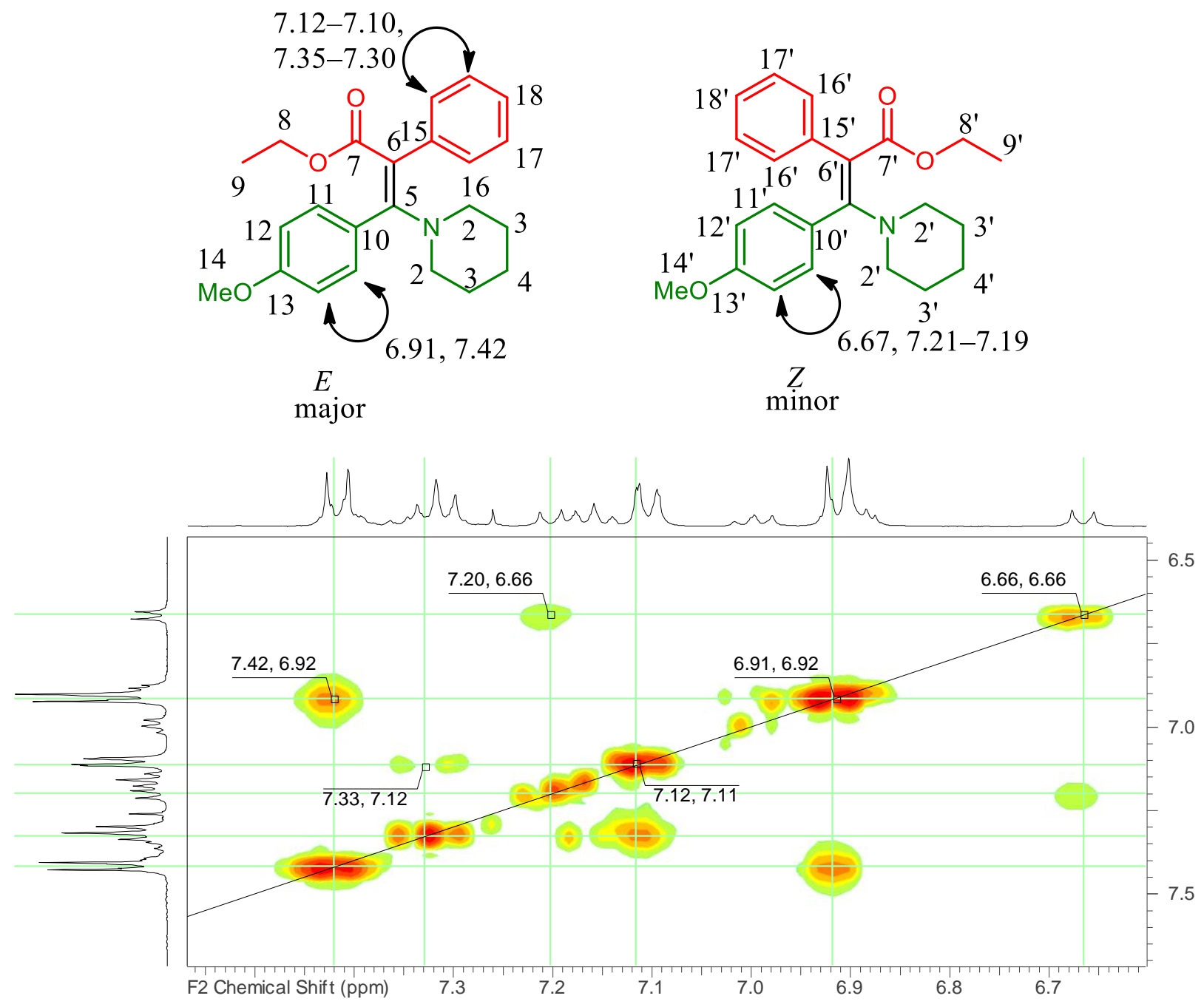
Figure S7. The key HMBC correlations shown below were used to confirm the position of indicated protons on the aromatic rings.
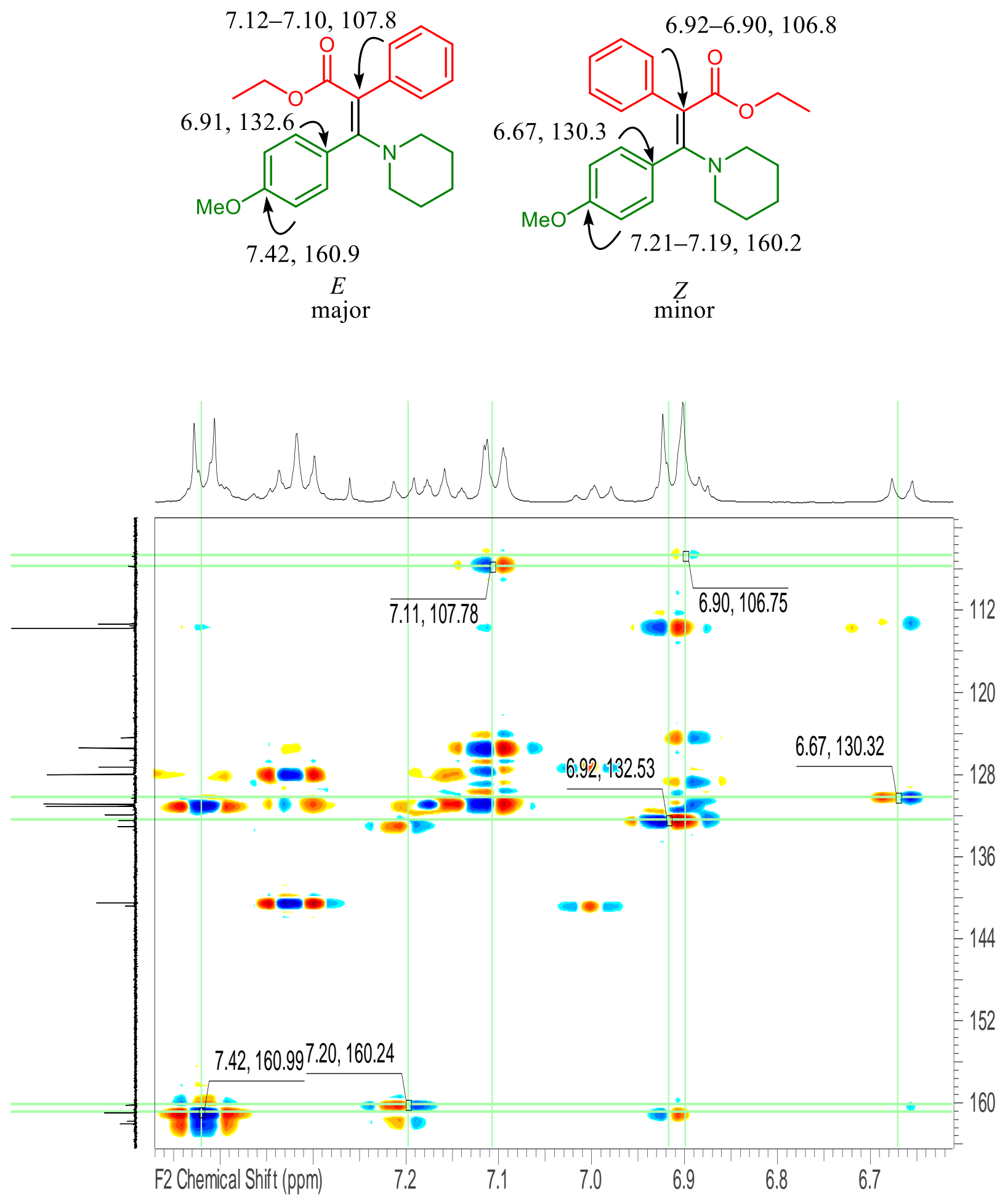


\section{Confirmation of $E / Z$ isomerization}

The four conformations of the compound that could provide different NMR signals are shown below (Figure S8). Either conformation of the $E$ isomer may show NOEs between the $\mathrm{C}(2)$ hydrogens and the aromatic hydrogen atoms, but it should not show NOEs between $\mathrm{C}(2)$ hydrogens and the ester hydrogen atoms. On the other hand, either conformation of the $Z$ isomer may show NOEs between $\mathrm{C}\left(2^{\prime}\right)$ protons and aromatic protons with the methoxy substituent, but it should not show NOEs between $\mathrm{C}\left(2^{\prime}\right)$ protons and the other aromatic ring (red) protons.<smiles>CCOC(=O)C(=C(c1ccc(OC)cc1)N1CCCCC1)c1ccccc1</smiles>

$E$<smiles>CCOC(=O)C(=C(c1ccc(OC)cc1)N1CCCCC1)c1ccccc1</smiles><smiles>CCOC(=O)C(=C(c1ccc(OC)cc1)N1CCCCC1)c1ccccc1</smiles>

E

major<smiles>CCOC(=O)C(=C(c1ccc(OC)cc1)N1CCCCC1)c1ccccc1</smiles>

minor

Figure S8. $E$ and $Z$ isomers 
Irradiation of $\mathrm{C}(2)$ protons of the major isomer shows NOE enhancements of protons of both aromatic rings, while $\mathrm{C}\left(2^{\prime}\right)$ protons of the minor isomer show NOE enhancements of the indicated aromatic ring and protons of the ester group. This information confirms that $\mathrm{C}(2)$ and $\mathrm{C}\left(2^{\prime}\right){ }^{1} \mathrm{H}$ NMR peaks show $E / Z$ isomers and not $s$-cis/s-trans type of isomers.

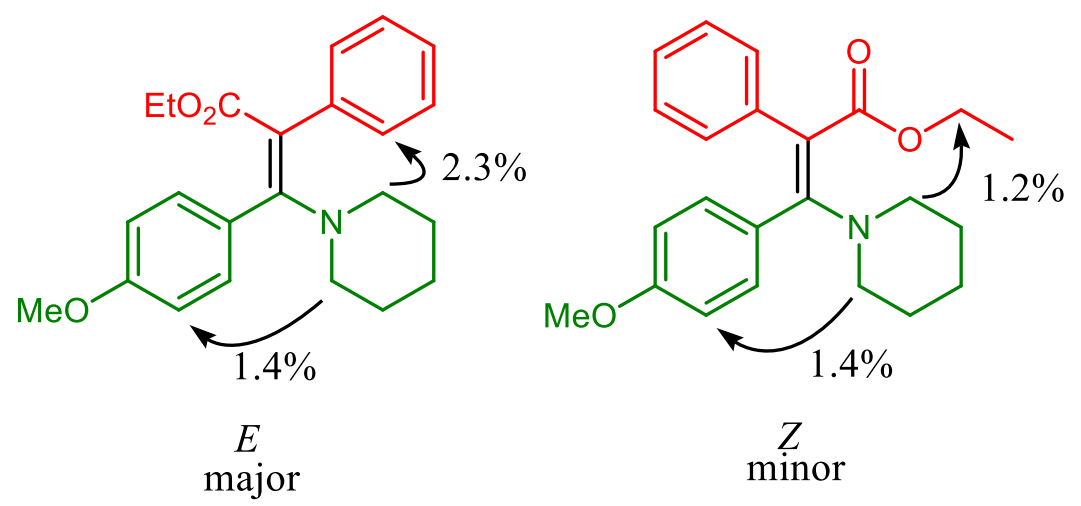

Figure S9. Selected 1D-NOESY data of $E$ and $Z$ isomers 


\section{Other 1-D and 2-D NMR spectra of 5 and 5,}

\section{1-D NOESY/EXSY of the mixture of 5 and 5'}

Figure S10. Number of scans $=256$, mixing time $=500 \mathrm{~ms}$, relaxation delay $=1.00 \mathrm{~s}$. Irradiation at 2.65 ppm

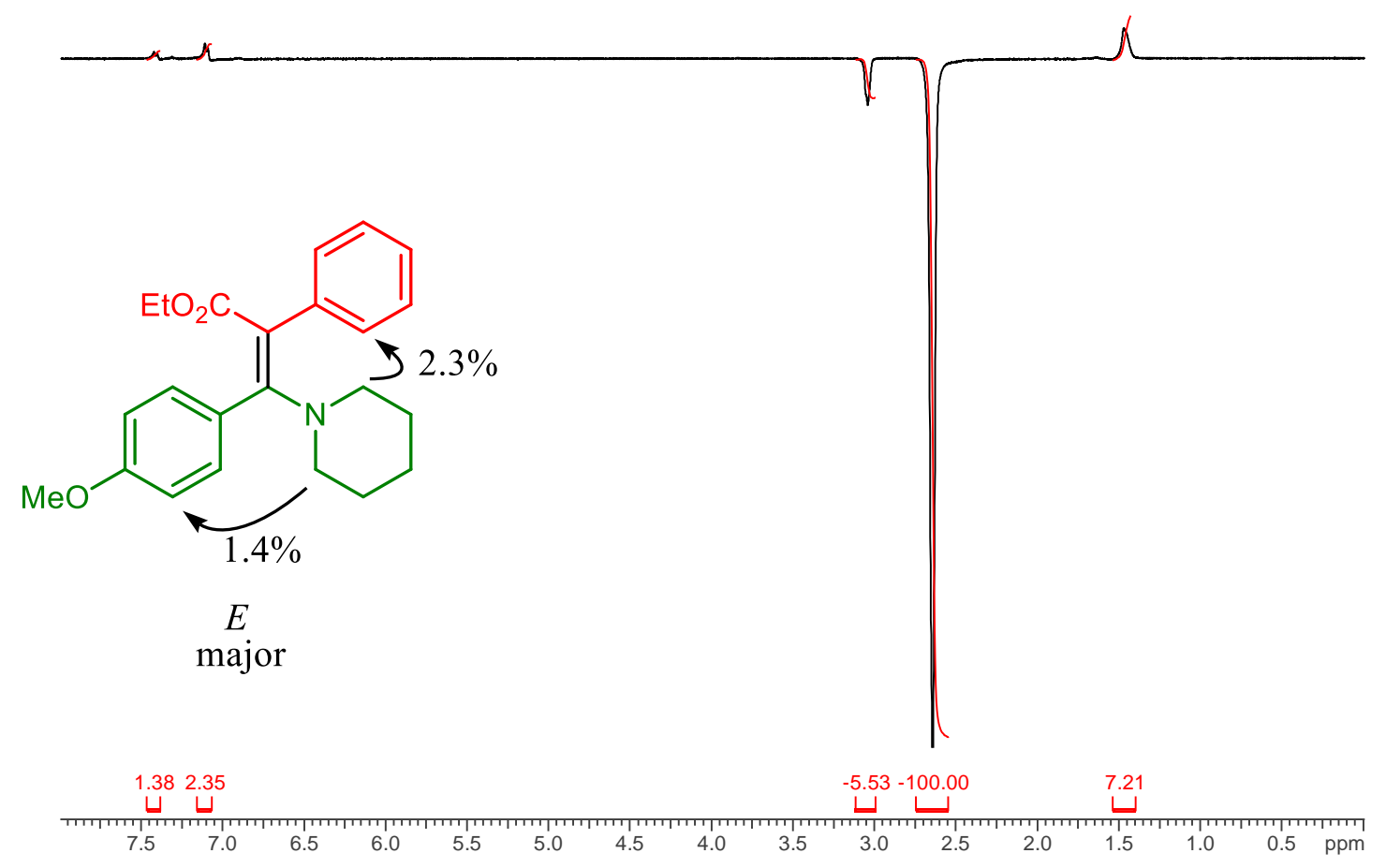

Figure S11. Number of scans $=1024$, mixing time $=500 \mathrm{~ms}$, relaxation delay $=1.00$. Irradiation at 3.05 ppm

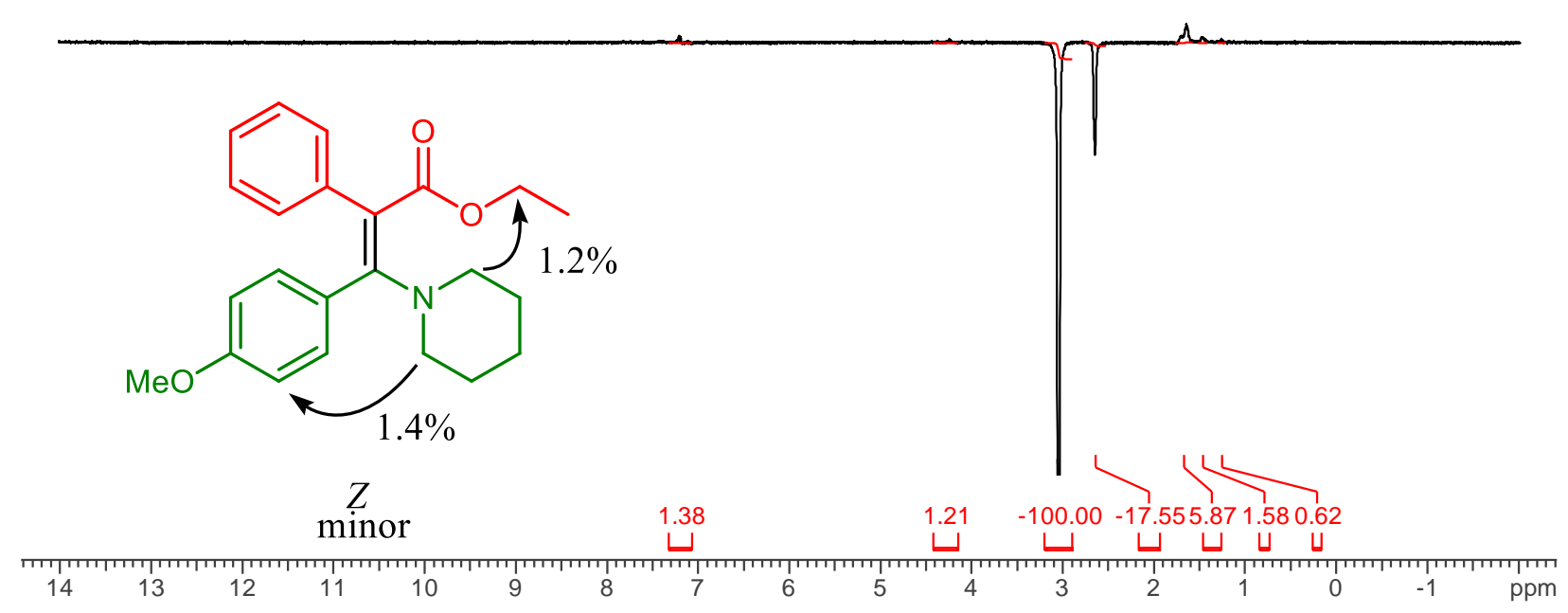


Figure S12. HSQC spectrum of the mixture of 5 and 5 '
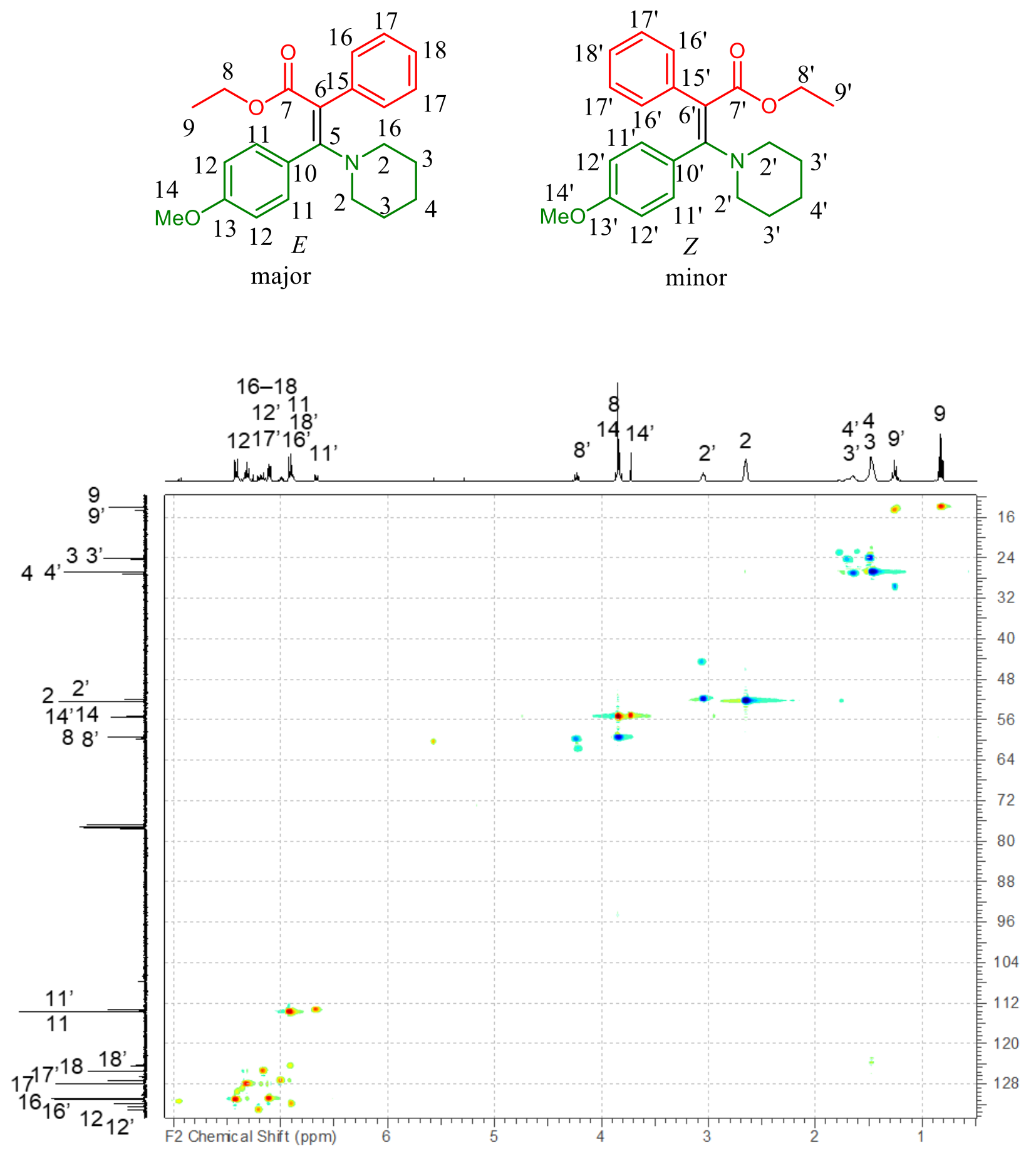
Figure S13. ${ }^{1} \mathrm{H}-{ }^{1} \mathrm{H}$ COSY spectrum of the mixture of 5 and 5',
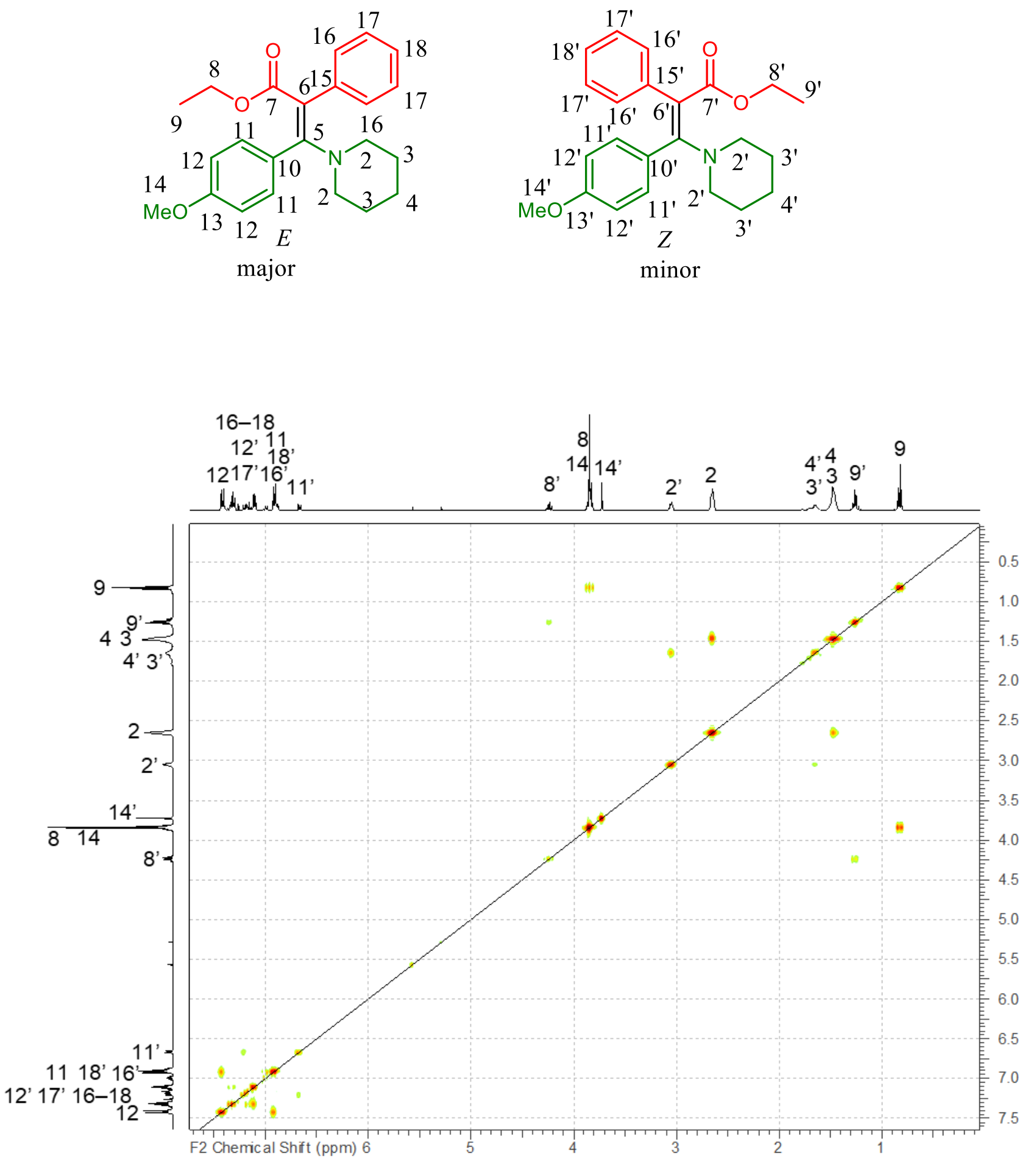
Figure S14. HMBC spectrum of the mixture of 5 and 5',
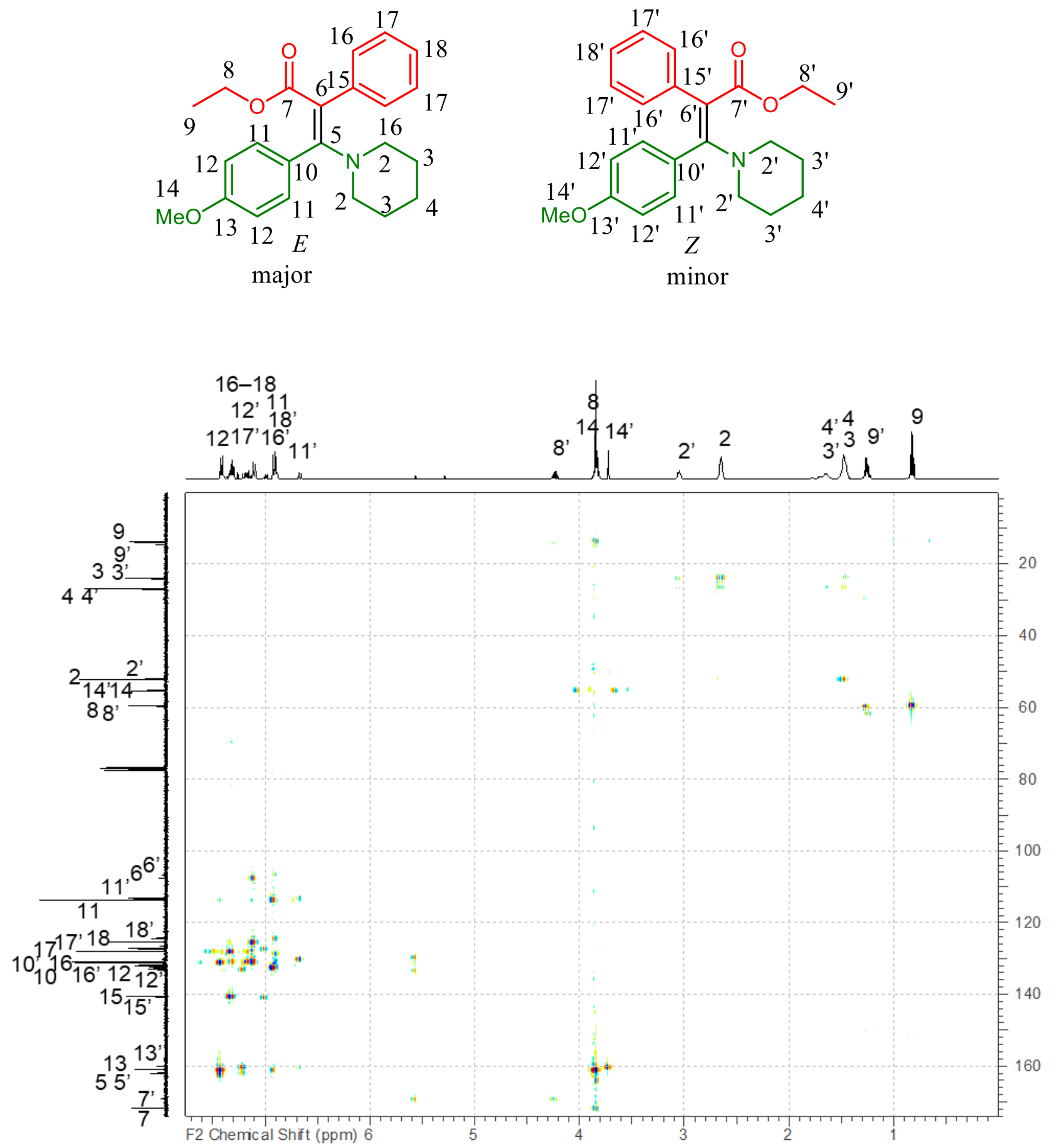
Figure S15. 2D-NOESY spectrum of the mixture of 5 and 5',
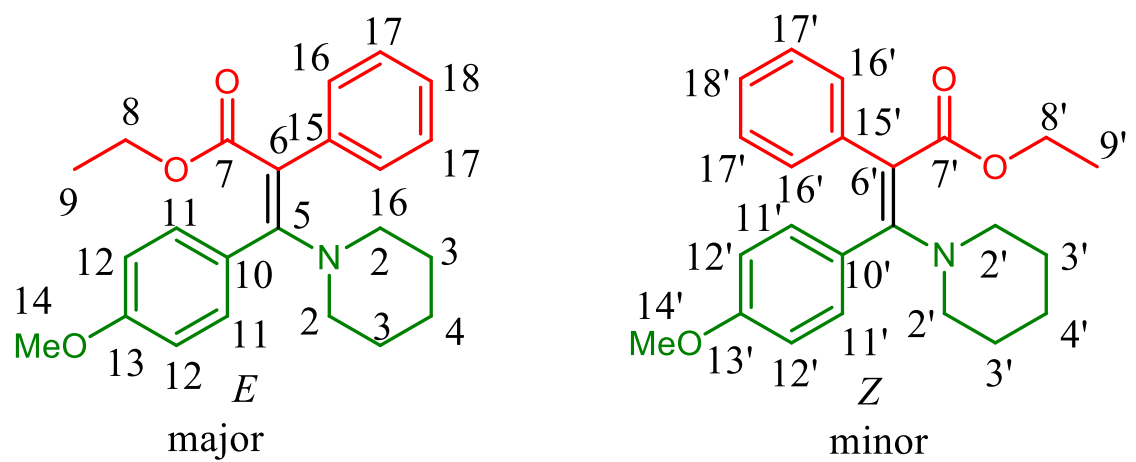

Number of scans $=8$, mixing time $=400 \mathrm{~ms}$, relaxation delay $=1.00 \mathrm{~s}$.

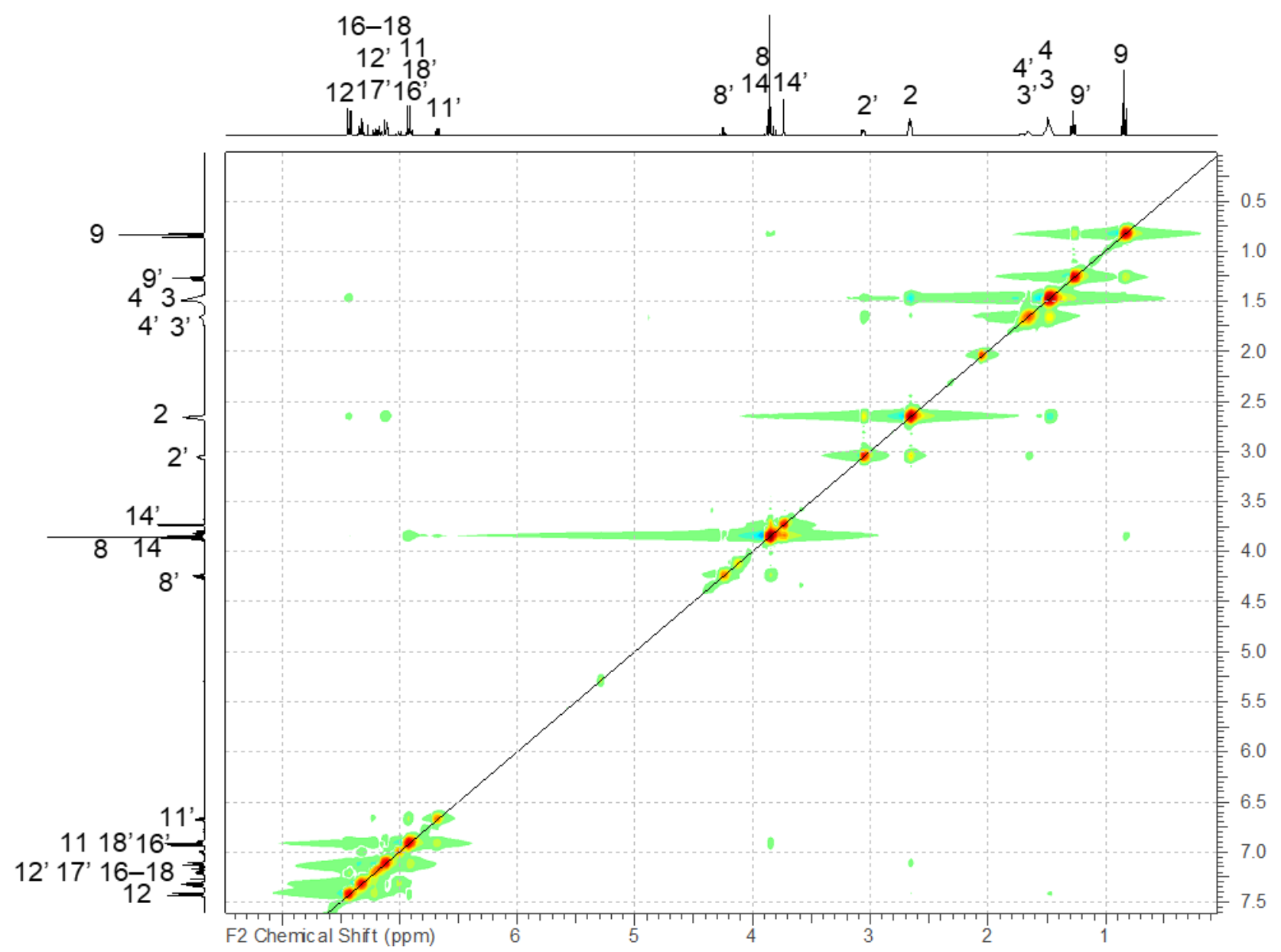


Figure S16. (E/Z)-1-(methylamino)pent-1-en-3-one.
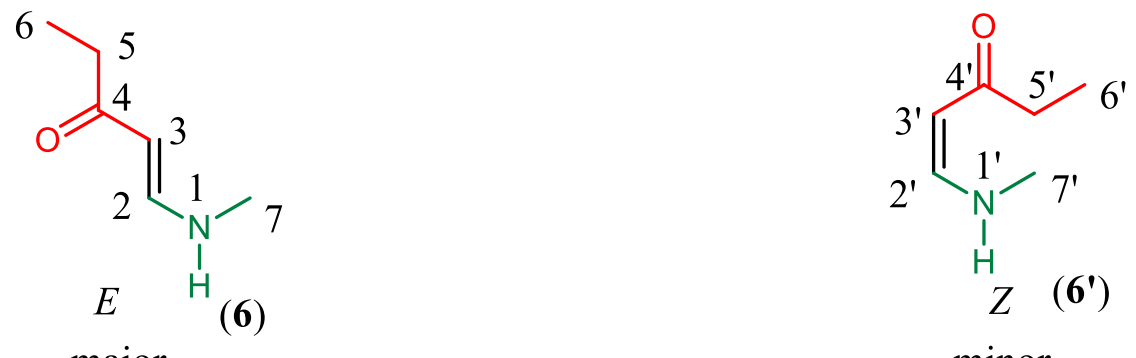

major

minor

Table S2. In $\mathrm{CDCl}_{3}$

\begin{tabular}{|c|c|c|c|c|c|}
\hline Position & $\begin{array}{c}\delta \mathrm{C} \\
\text { (major) }\end{array}$ & $\begin{array}{c}\delta \mathrm{H} \text { (major, 6) } J \text { in } \\
\mathrm{Hz}\end{array}$ & Position & $\begin{array}{c}\delta \mathrm{C} \\
\text { (minor) }\end{array}$ & $\delta \mathrm{H}$ (minor, 6') $J$ in Hz \\
\hline 2 & 149.2 & $7.14-6.95(\mathrm{br}, \mathrm{m})$ & 2 & 153.0 & $6.08, \mathrm{dd}(7.6,12.8)$ \\
\hline 3 & 93.7 & $4.49, \mathrm{~d}(12.4)$ & $3^{\prime}$ & 91.1 & $4.32, \mathrm{~d}(7.6)$ \\
\hline 4 & 197.6 & & $4^{\prime}$ & 198.9 & \\
\hline 5 & 32.2 & $1.72, \mathrm{q}(7.2)$ & $5^{\prime}$ & 33.4 & $1.60, \mathrm{q}(7.6)$ \\
\hline 6 & 8.6 & $0.43, \mathrm{t}(7.2)$ & $6^{\prime}$ & 8.6 & $0.41, \mathrm{t}(7.6)$ \\
\hline 7 & 28.3 & $2.10(\mathrm{br}, \mathrm{s})$ & 7 & 33.7 & $2.32, \mathrm{~d}(4.8)$ \\
\hline $\mathrm{NH}$ & & $6.74(\mathrm{br}, \mathrm{s})$ & $\mathrm{NH}$ & & $9.00(\mathrm{br}, \mathrm{s})$ \\
\hline
\end{tabular}


Figure S17. ${ }^{1} \mathrm{H}$ NMR of the mixture of 6 and 6 '

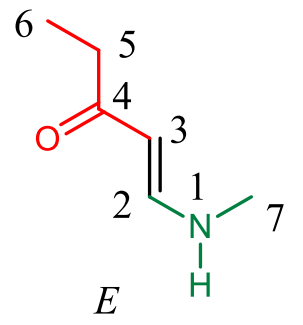

major

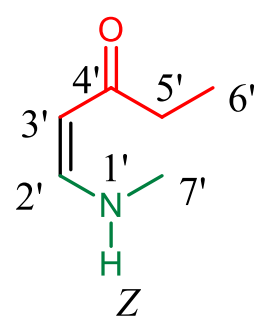

minor
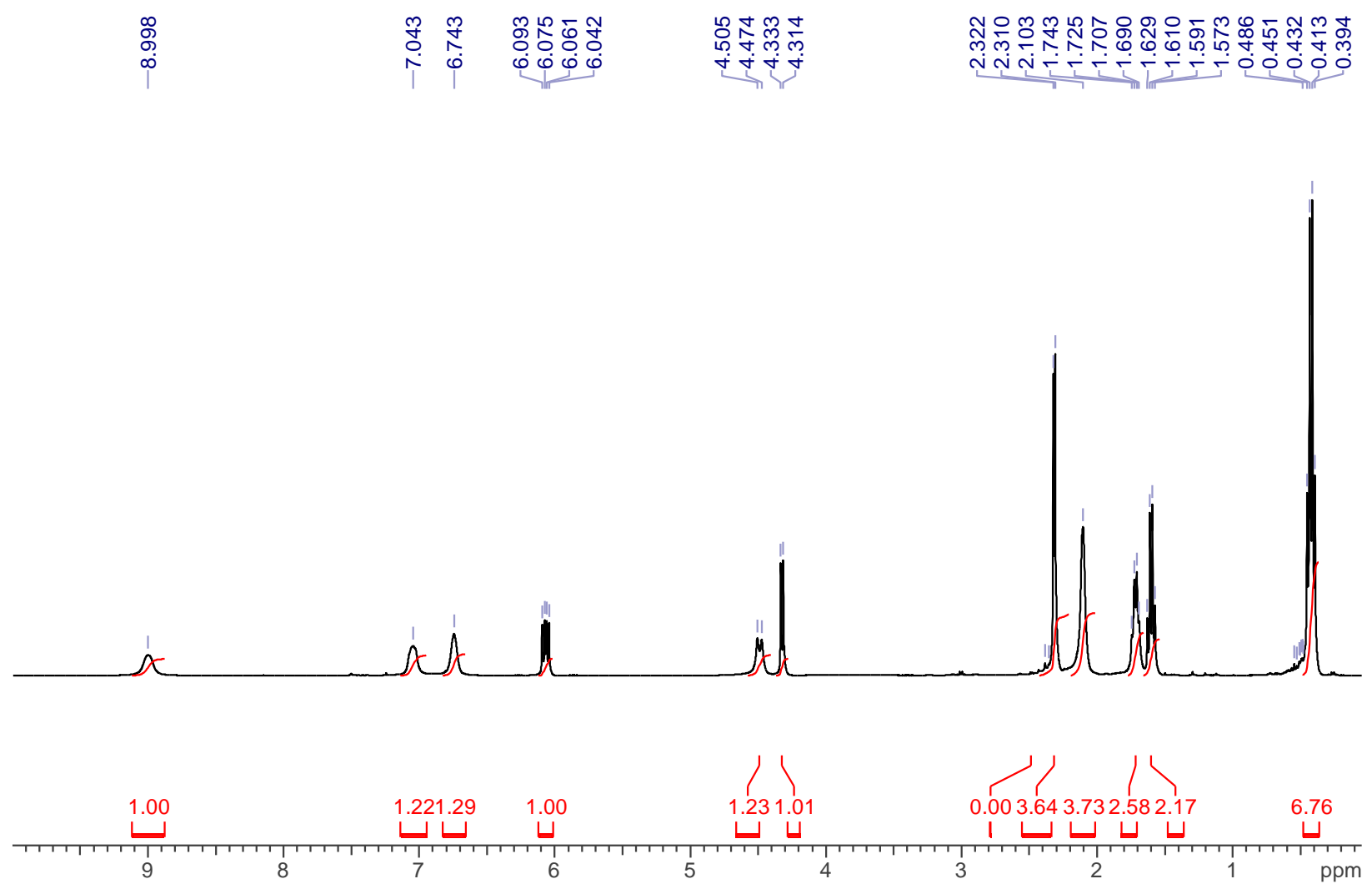
Figure S18. ${ }^{13} \mathrm{C}$ NMR of the mixture of 6 and $6^{\prime}$

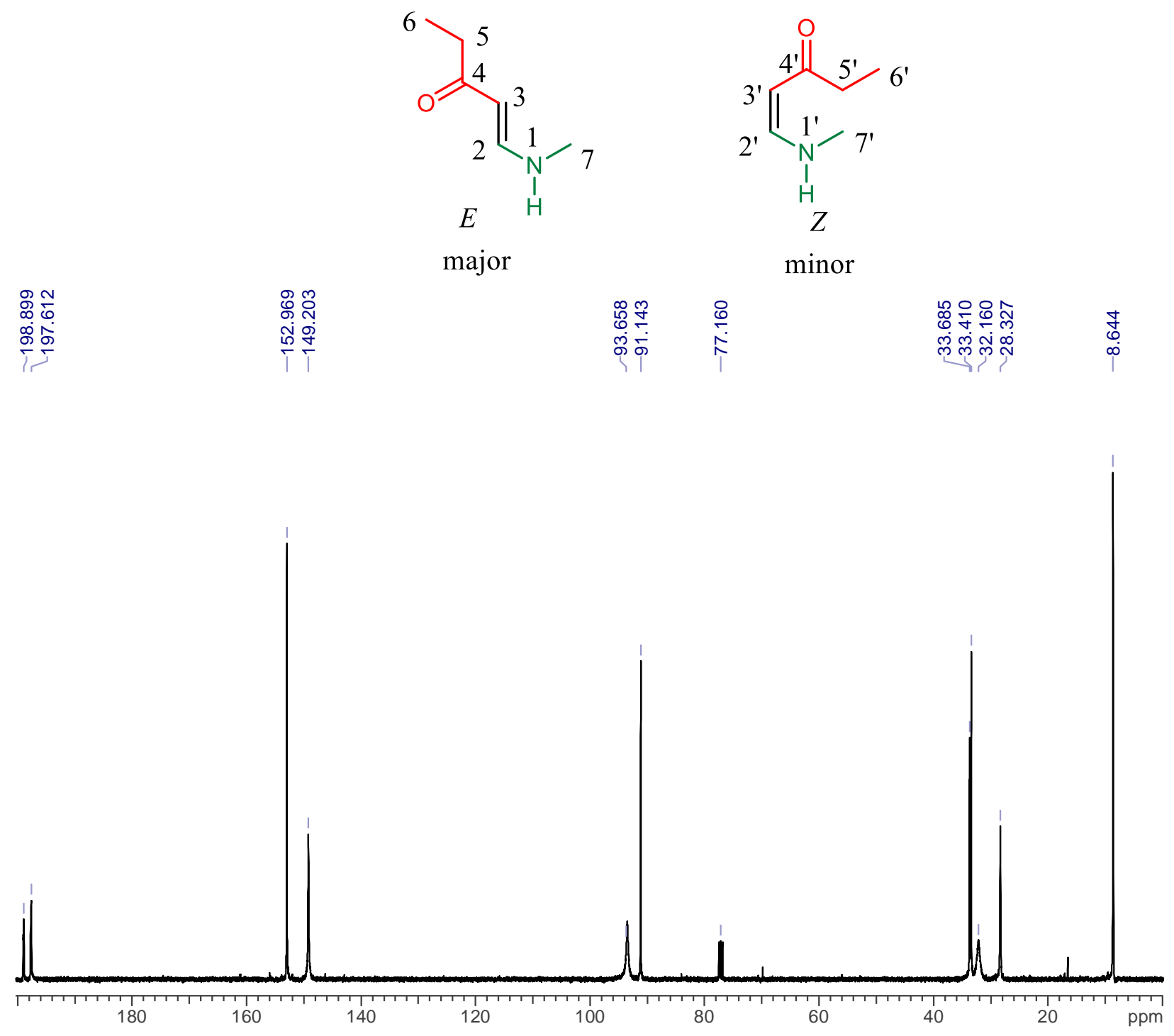


Other 1-D and 2-D NMR spectra of 6 and 6'

Figure S19. ${ }^{1} \mathrm{H}$ NMR at a lower concentration of the sample of 6 and 6 '

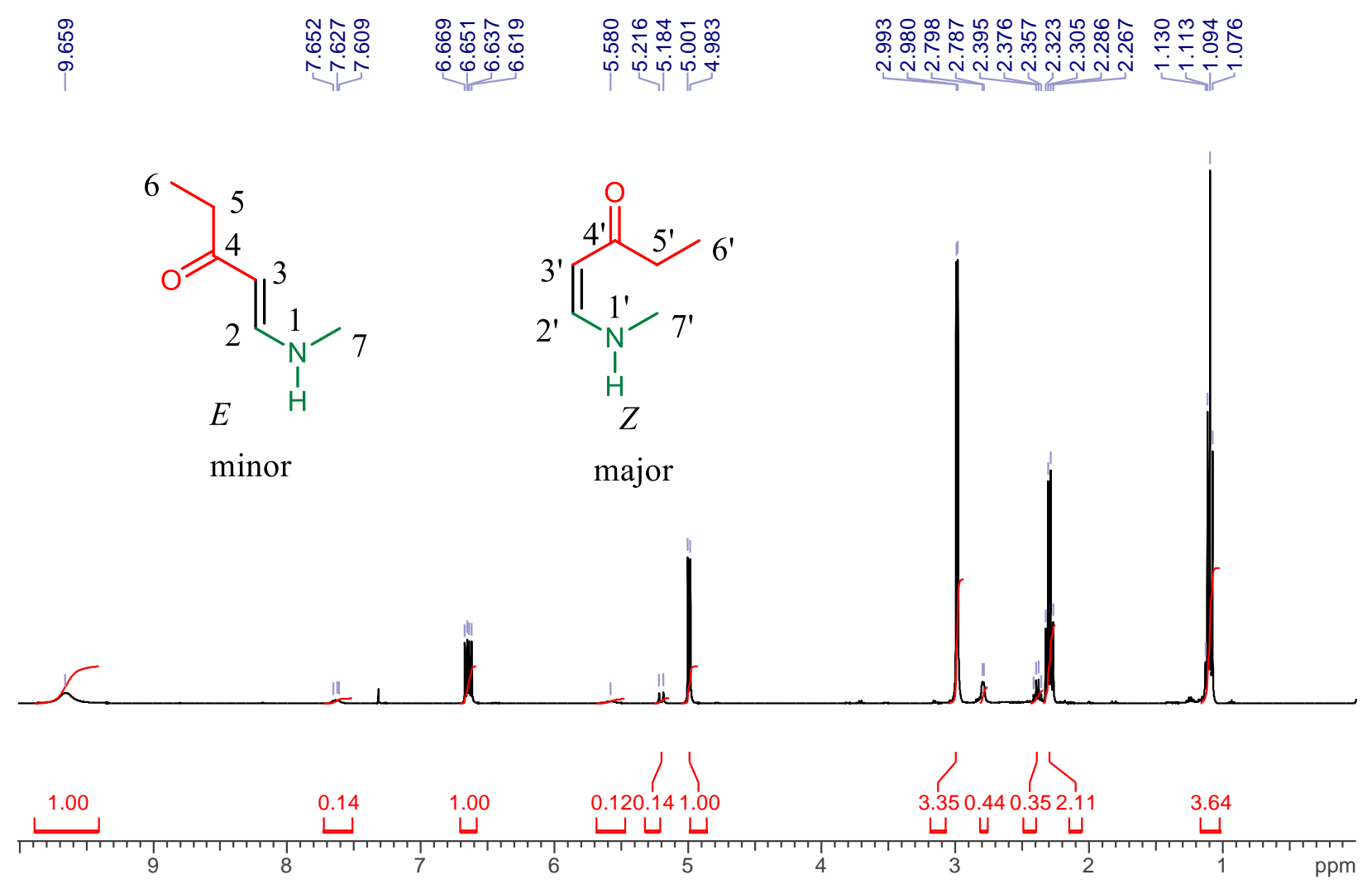


Figure S20. ${ }^{1} \mathrm{H}-{ }^{1} \mathrm{H}$ COSY spectrum of the mixture of 6 and 6 '

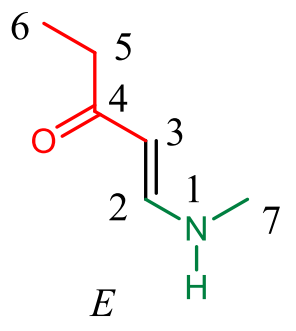

major

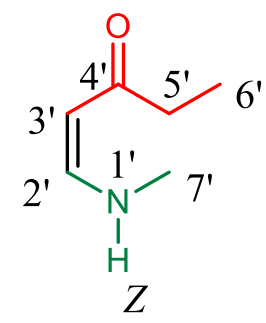

minor

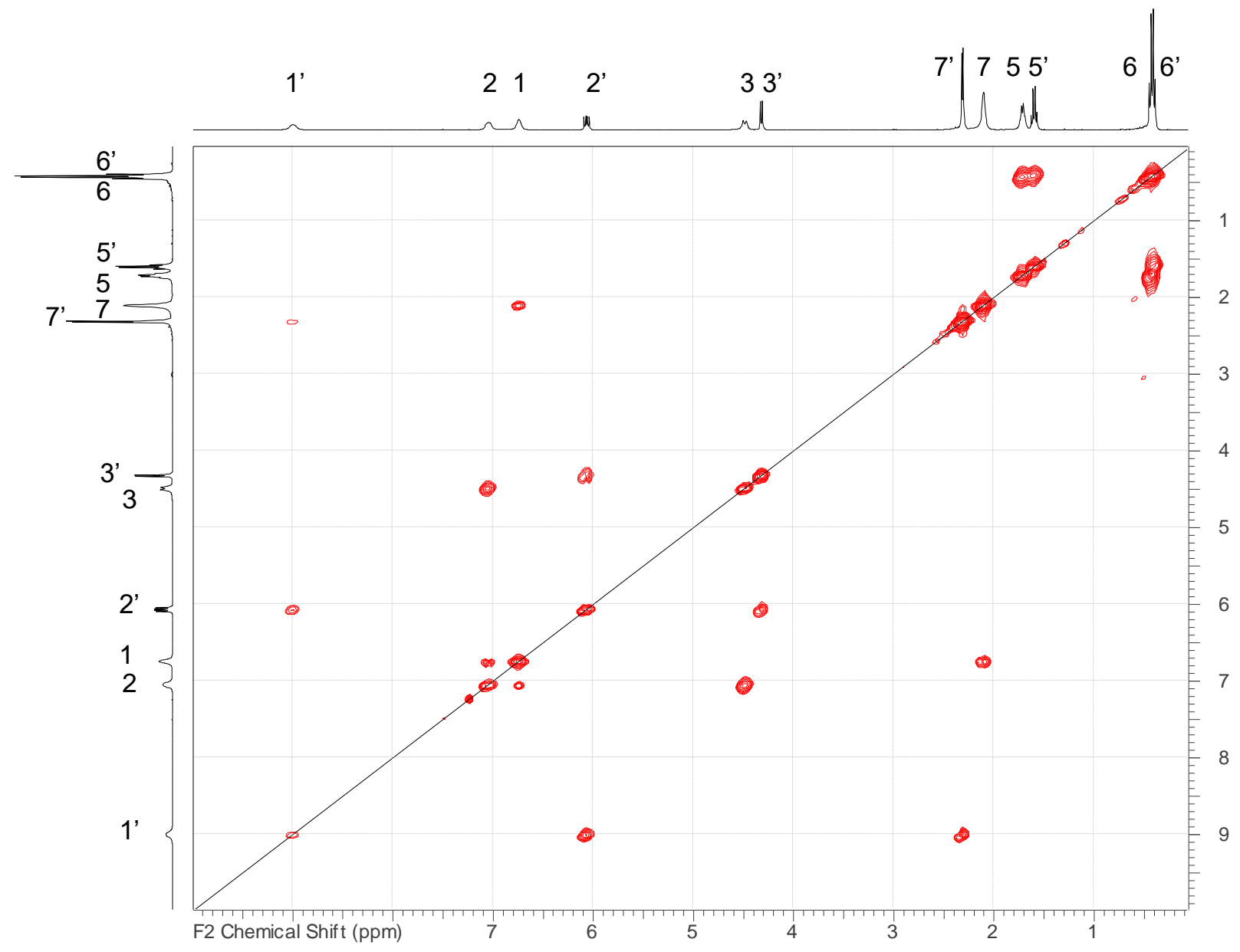


Figure S21. HSQC spectrum of the mixture of 6 and 6 '

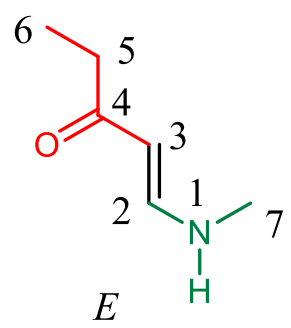

major

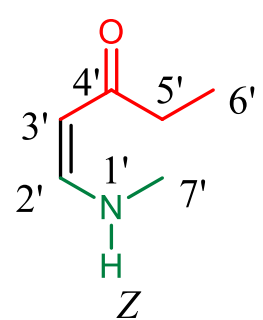

minor

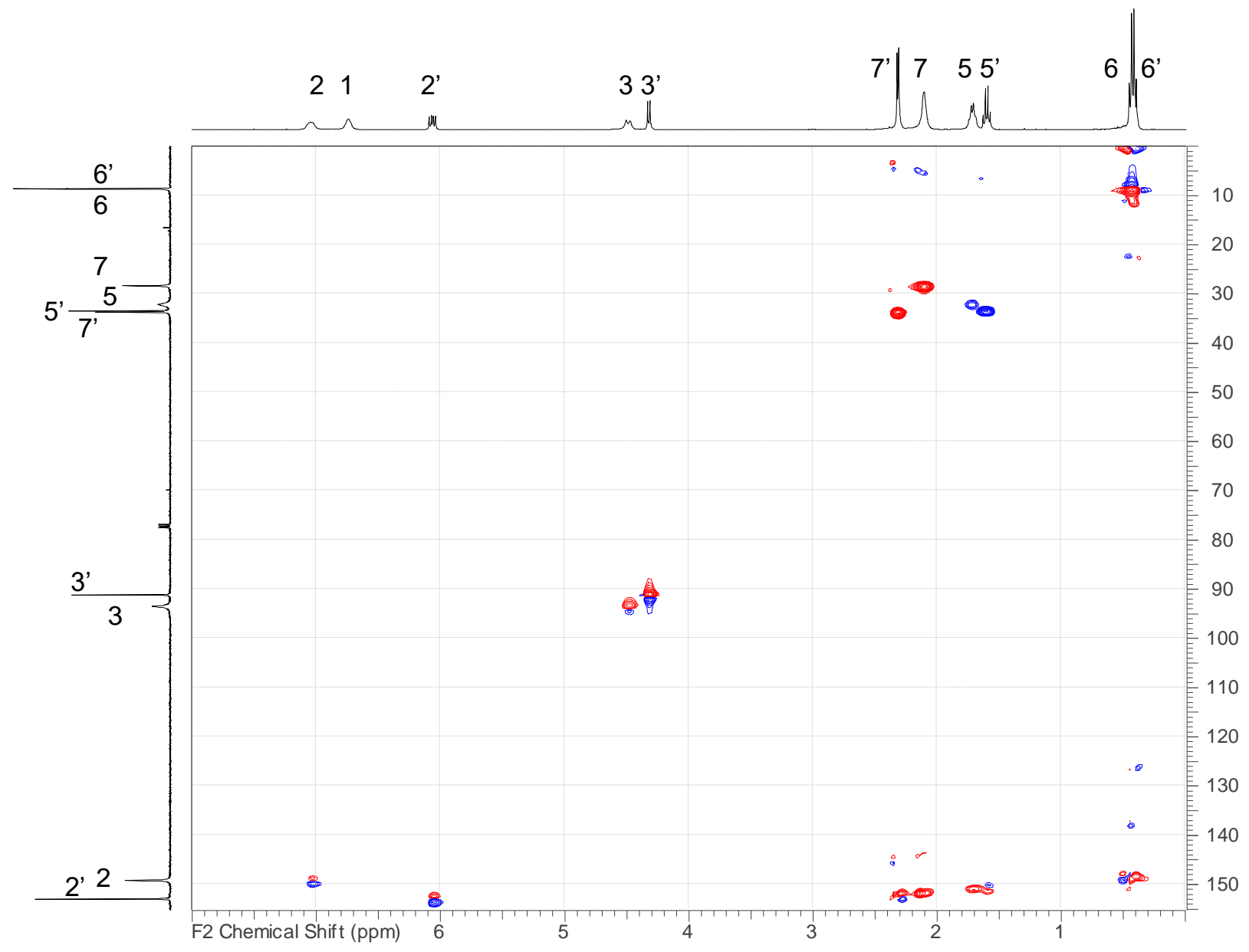


Figure S22. 2D-NOESY/EXSY spectrum of the mixture of 6 and 6'

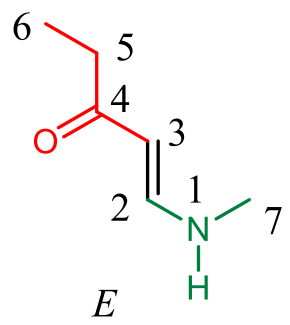

major

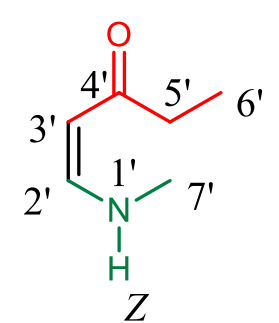

minor

Number of scans $=125$, mixing time $=1,000 \mathrm{~ms}$, relaxation delay $=1.00 \mathrm{~s}$.

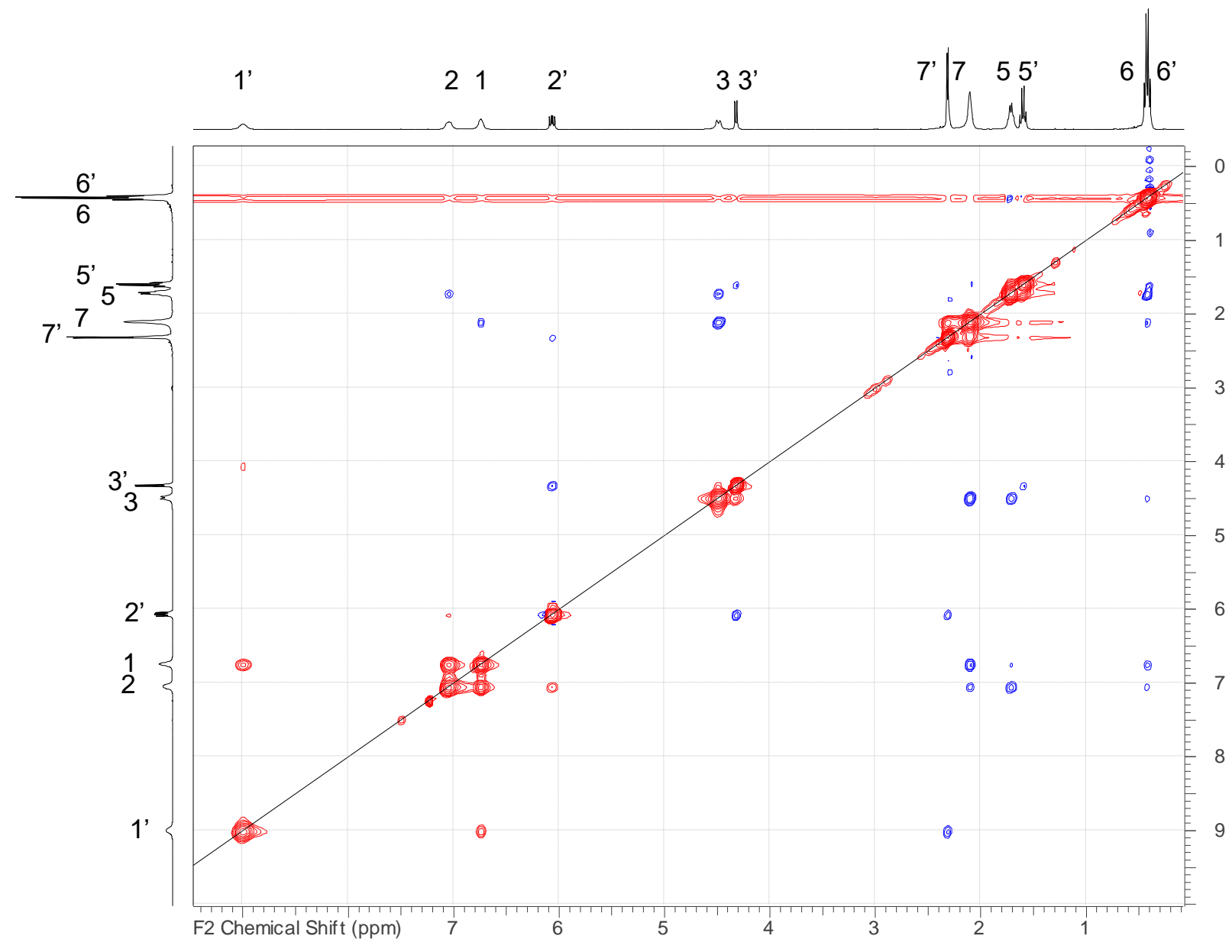


Figure S23. 1D-NOESY/EXSY of the mixture of 6 and 6'

Number of scans $=608$, mixing time $=500 \mathrm{~ms}$, relaxation delay $=1.00 \mathrm{~s}$.

Irradiation at $2.10 \mathrm{ppm}$

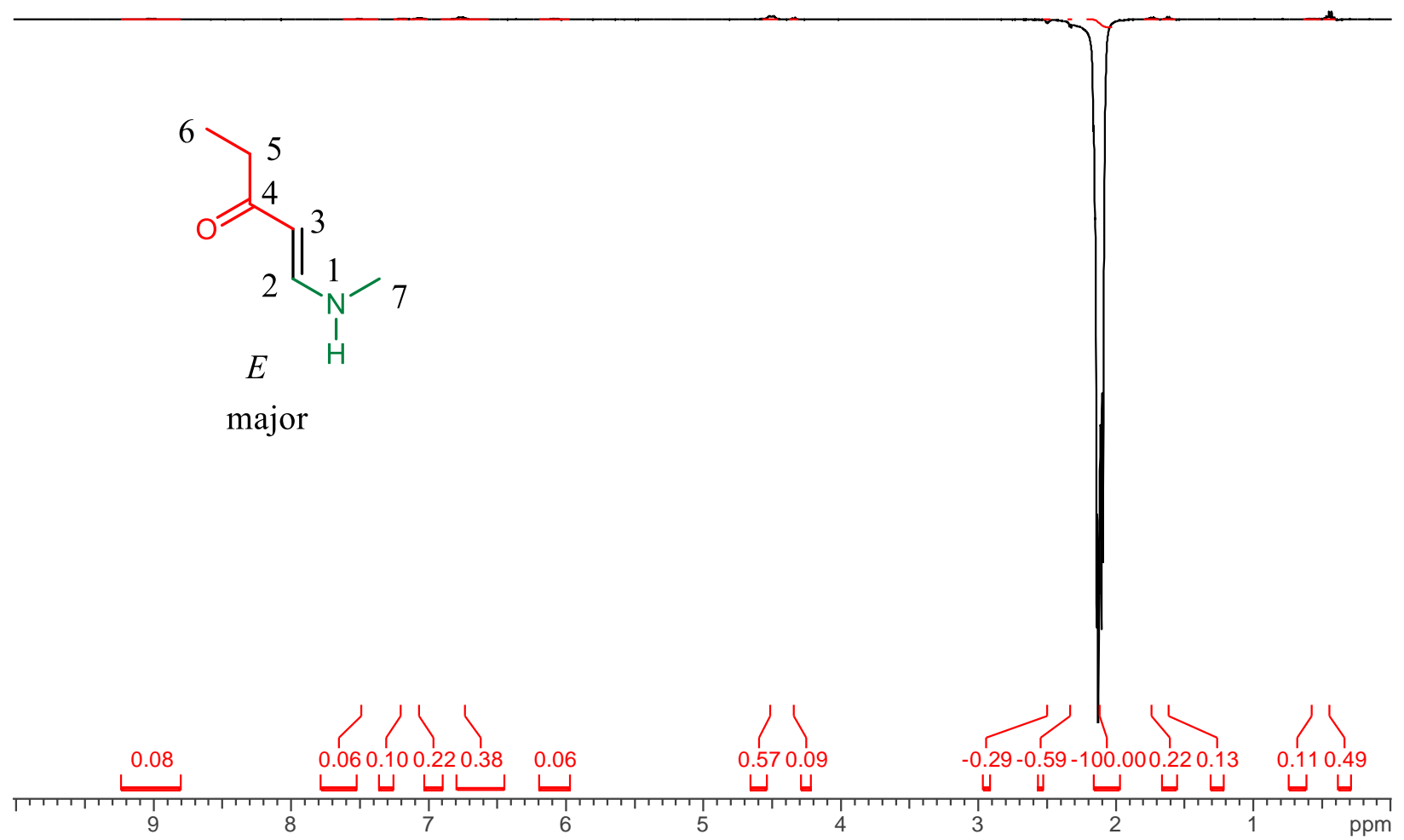


Figure S24. Number of scans $=17,840$, mixing time $=500 \mathrm{~ms}$, relaxation delay $=1.00 \mathrm{sec}$.

Irradiation at $2.32 \mathrm{ppm}$

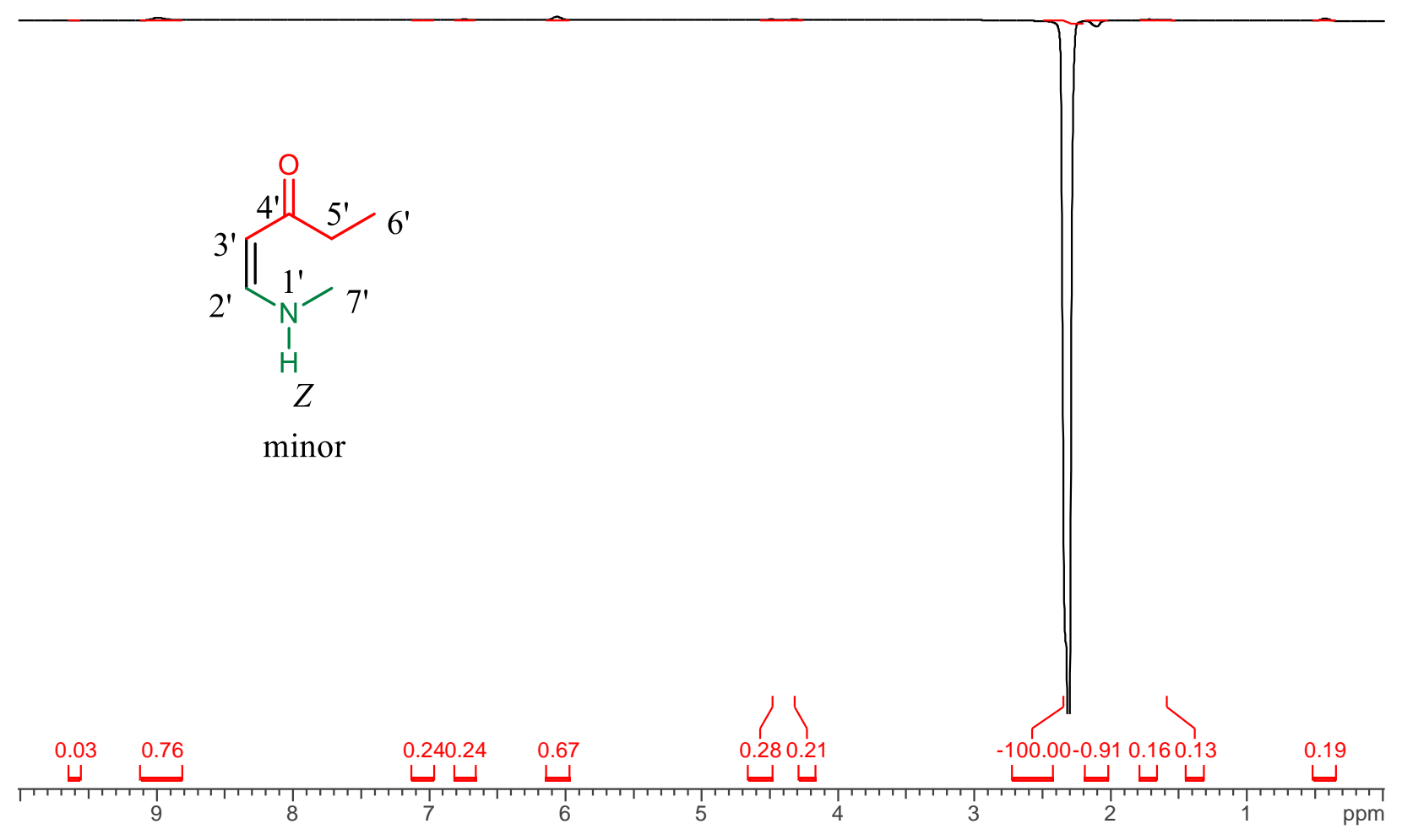


Figure S25. Variable Temperature ${ }^{1} \mathrm{H}-\mathrm{NMR}$ Spectra

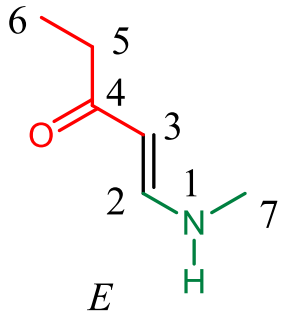

major

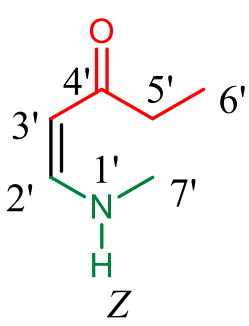

minor

Broadening of peaks indicates an approach to the coalescence point. Temperature was calibrated with methanol. Non-calibrated temperatures are reported as "nominal" and calibrated temperatures are reported as "actual."

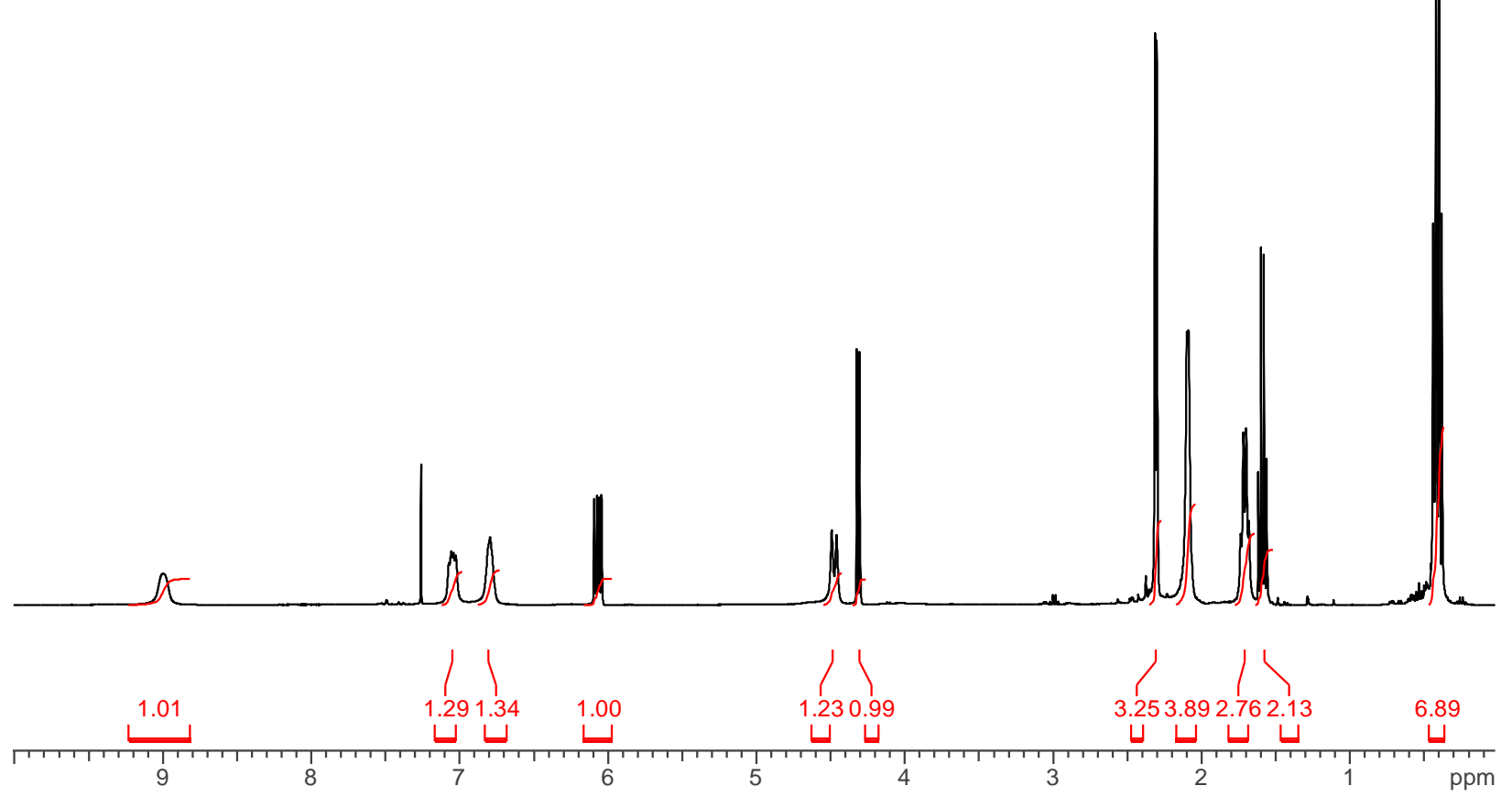


Figure S26. Nominal $10{ }^{\circ} \mathrm{C}$, actual $10.1{ }^{\circ} \mathrm{C}$

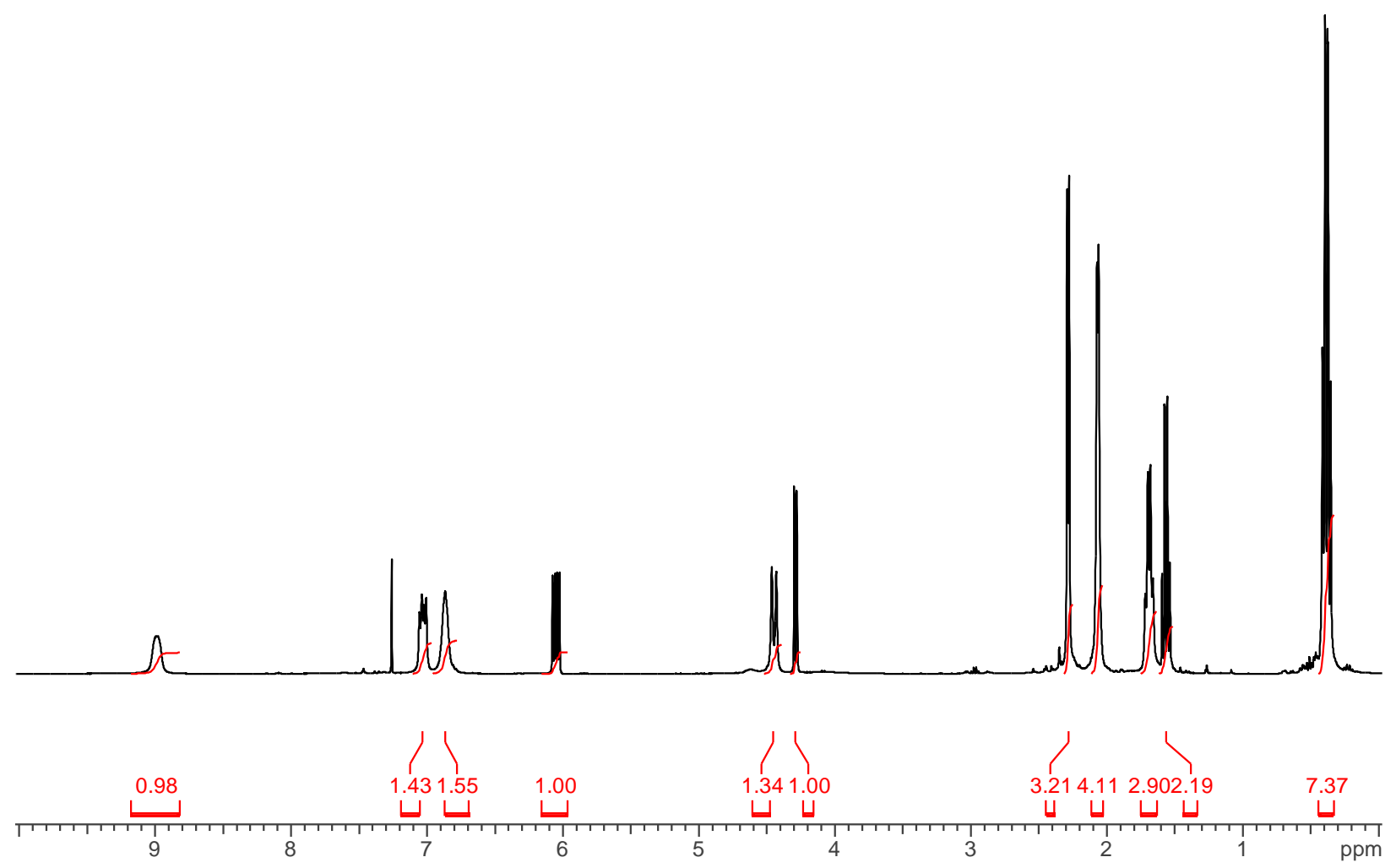

Figure S27. Nominal $0{ }^{\circ} \mathrm{C}$, actual $-0.6^{\circ} \mathrm{C}$

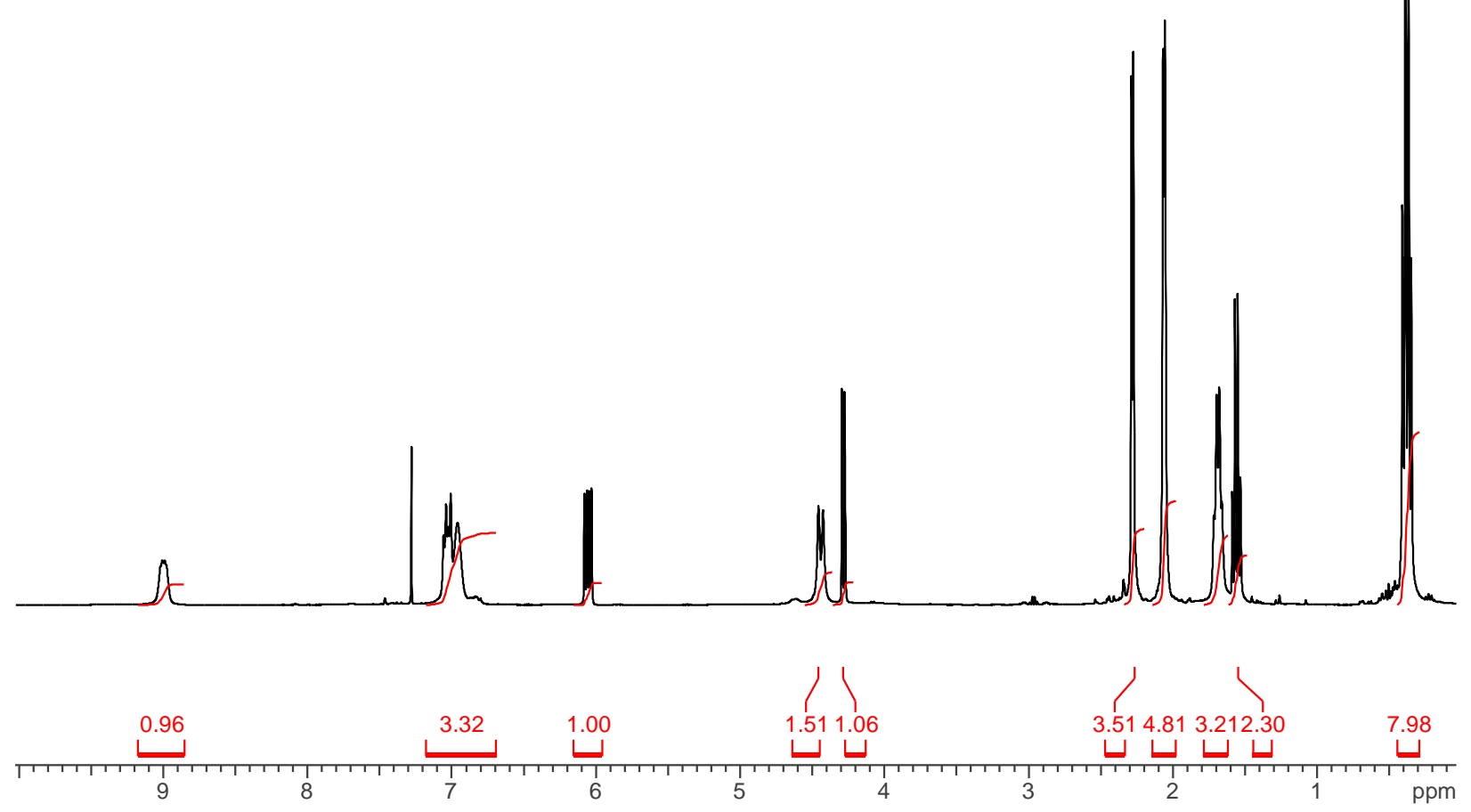


Figure S28. Nominal $-10{ }^{\circ} \mathrm{C}$, actual $-11.3^{\circ} \mathrm{C}$

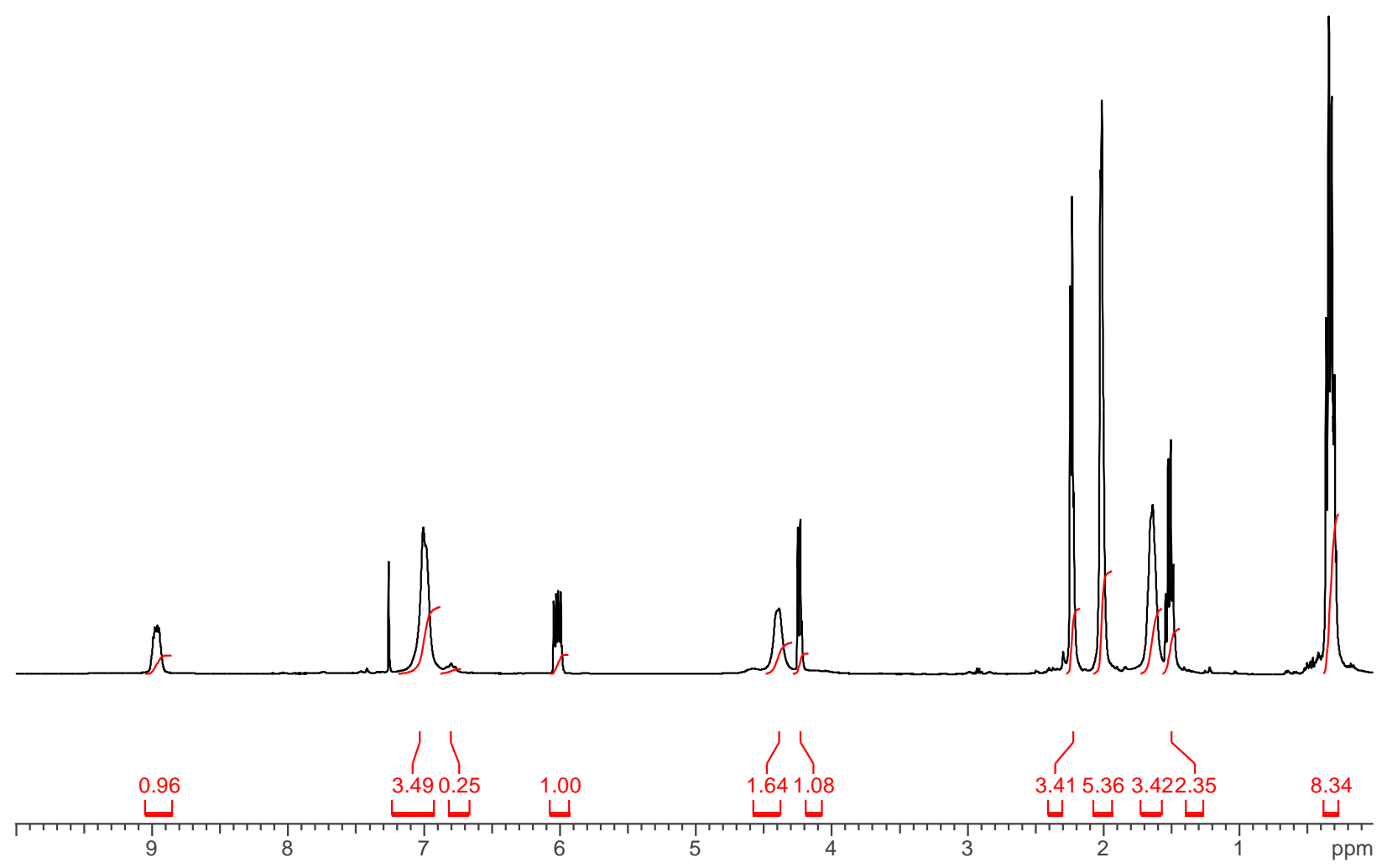

Figure S29. Nominal $-10{ }^{\circ} \mathrm{C}$, actual $-21.3{ }^{\circ} \mathrm{C}$

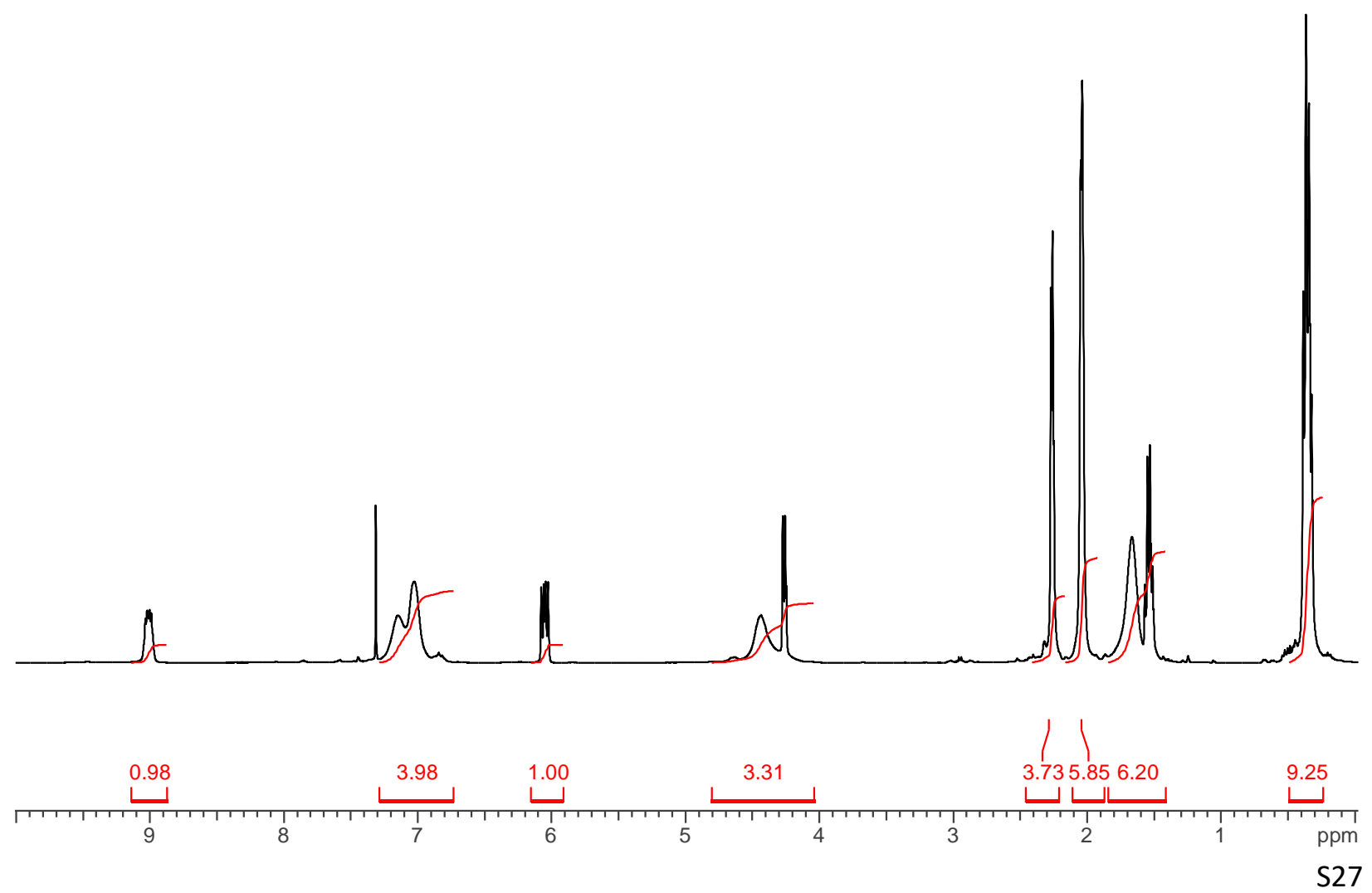


Figure S30. Nominal $-30{ }^{\circ} \mathrm{C}$, actual $-32.6{ }^{\circ} \mathrm{C}$

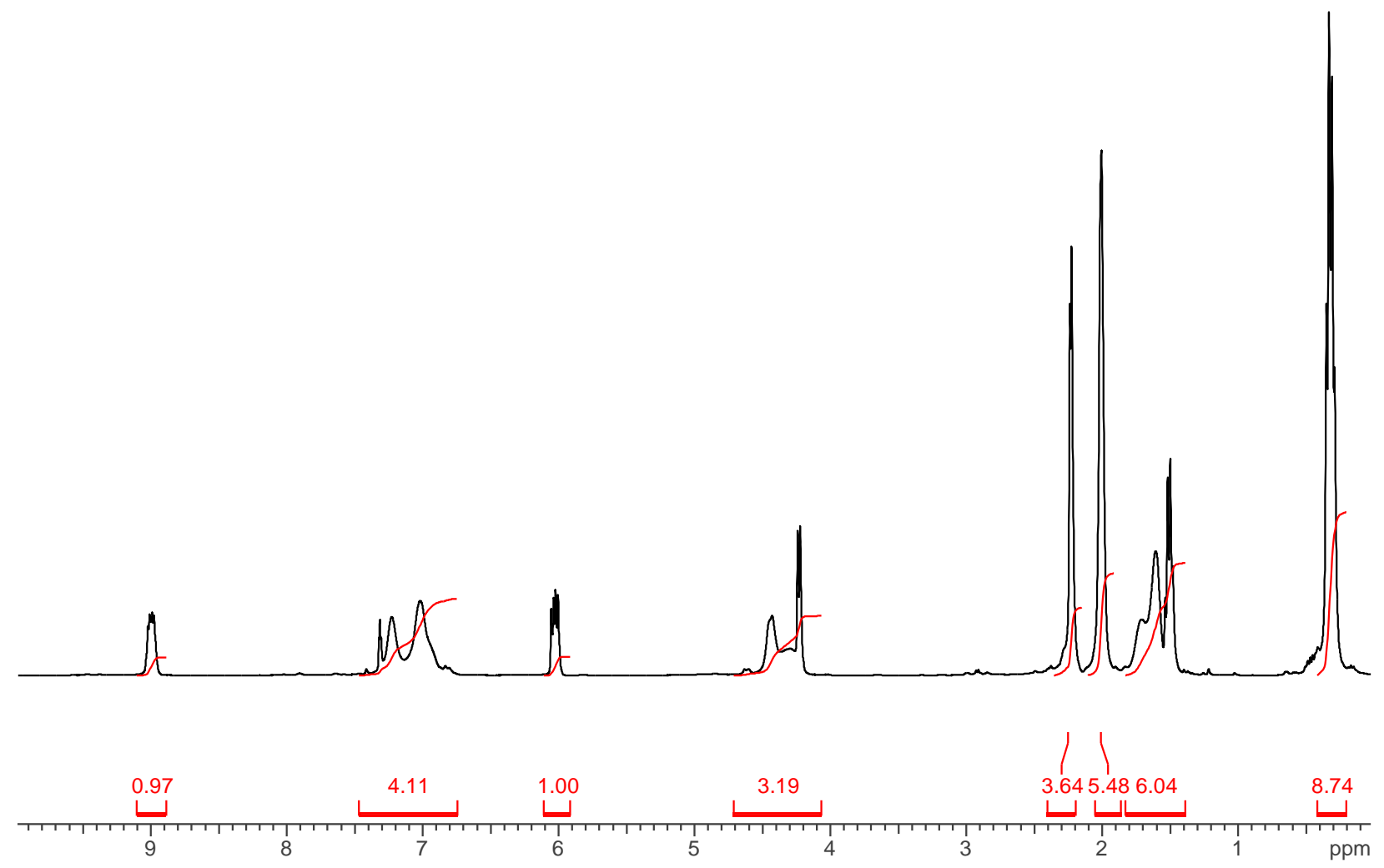

Figure S31. Nominal $-40{ }^{\circ} \mathrm{C}$, actual $-42.6^{\circ} \mathrm{C}$

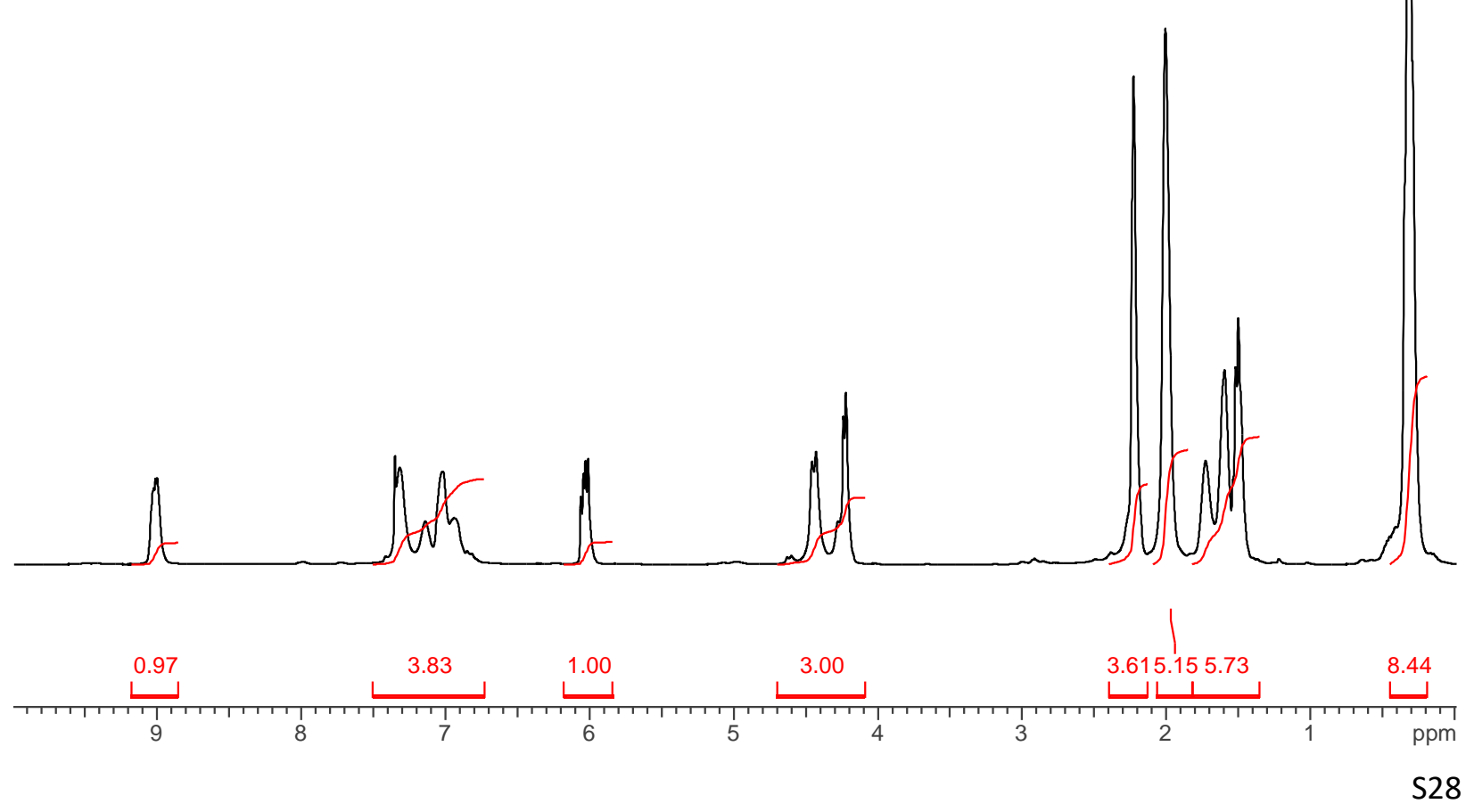


Figure S32. Nominal $-50{ }^{\circ} \mathrm{C}$, actual $-52.8^{\circ} \mathrm{C}$

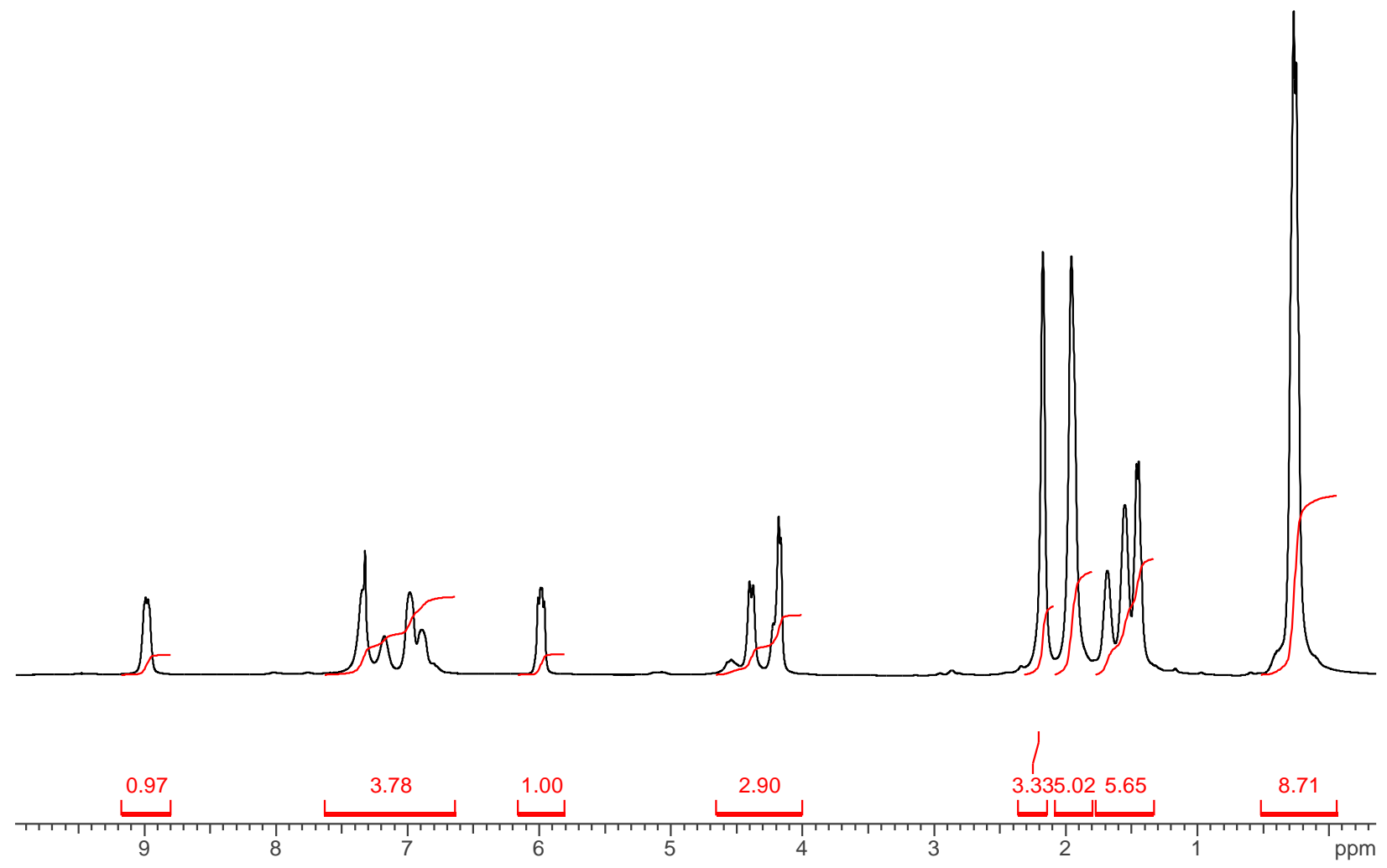


Figure S33. Stacked and expanded VT ${ }^{1} \mathrm{H}$ NMR

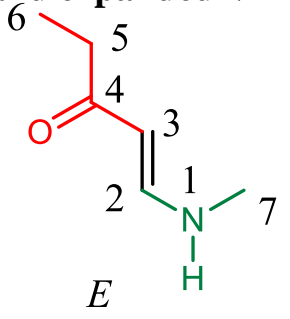

major 6

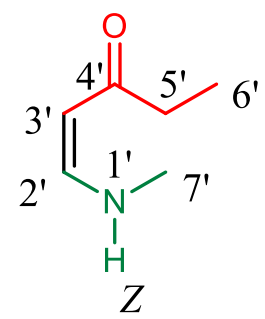

minor $\mathbf{6}^{\prime}$

For clarity, only nominal temperatures are shown below.

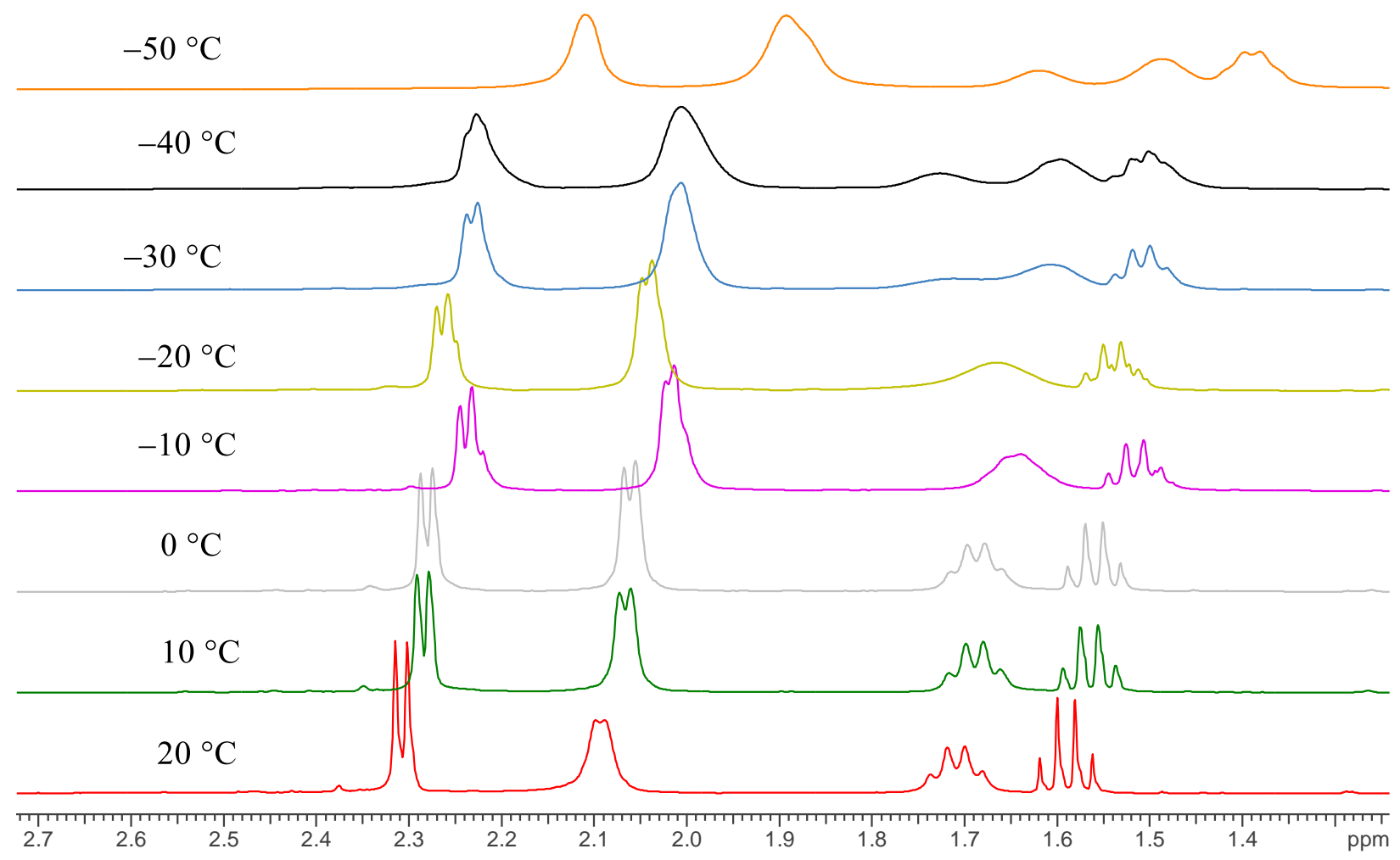


Figure S34. Stilbene Mixture

Ratio $=$ trans $:$ cis $; 0.8: 1$<smiles>C/C(=C/c1ccccc1)c1ccccc1</smiles><smiles>[Tl]=C(c1ccccc1)c1ccccc1</smiles>

Table S3. In $\mathrm{CDCl}_{3}$.

\begin{tabular}{|c|c|c|c|}
\hline Position & $\begin{array}{c}\delta \mathrm{H} \text { (major) } J \text { in } \\
\mathrm{Hz}\end{array}$ & Position & $\begin{array}{c}\delta \mathrm{H} \text { (minor) } J \text { in } \\
\mathrm{Hz}\end{array}$ \\
\hline 1 & $6.58, \mathrm{~s}$ & $1^{\prime}$ & $7.10, \mathrm{~s}$ \\
\hline 2 & \multirow{3}{*}{$7.25-7.15, \mathrm{~m}$} & $2^{\prime}$ & $7.50, \mathrm{~d}(7.6)$ \\
\cline { 4 - 4 } & & $3^{\prime}$ & $7.34, \mathrm{dd}(7.6,8.4)$ \\
\hline 3 & & $4^{\prime}$ & $7.25-7.15, \mathrm{~m}$ \\
\hline 4
\end{tabular}


Figure S35. ${ }^{1} \mathrm{H}-\mathrm{NMR}$ in $\mathrm{CDCl}_{3}$

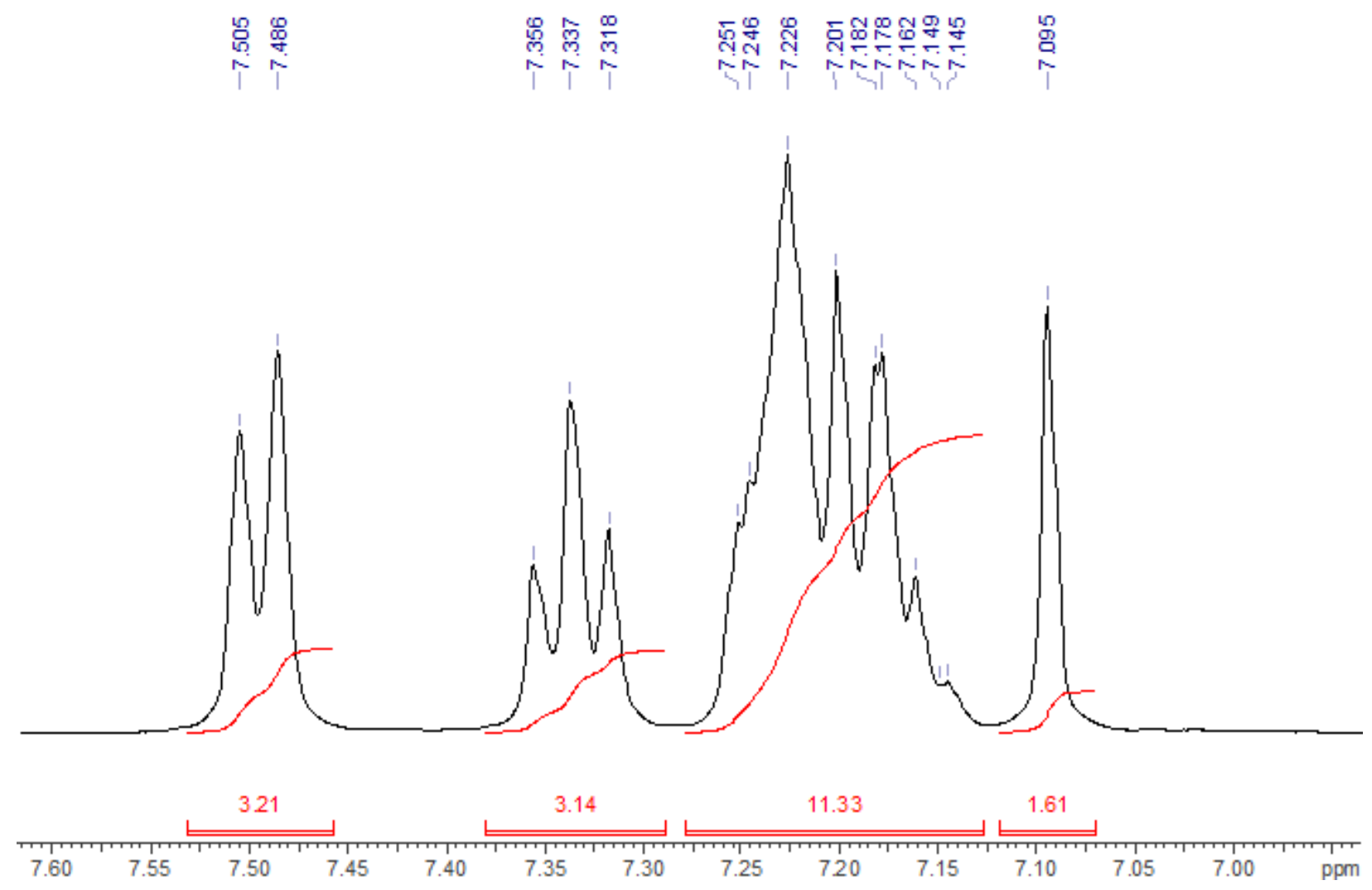




\section{Figure S36. 1D-NOESY of the stilbene mixture}

Number of scans $=256$, mixing time $=500 \mathrm{~ms}$, relaxation delay $=1.00 \mathrm{sec}$.

Irradiation at $6.58 \mathrm{ppm}$

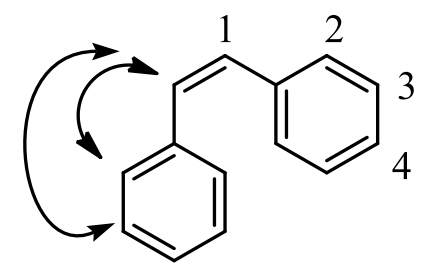

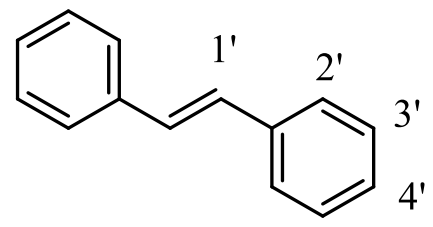

ペָ

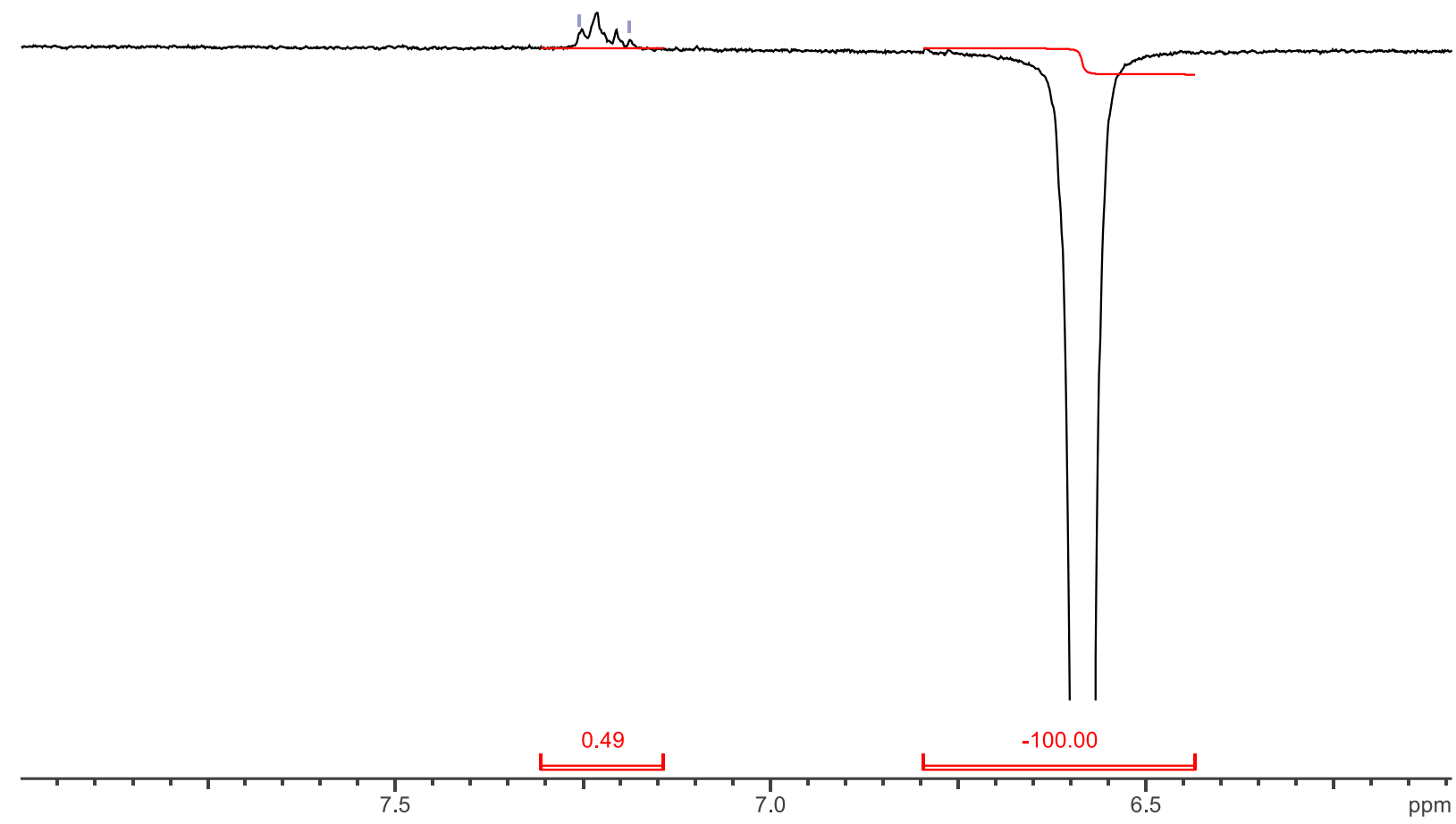


Figure S37. 2D-NOESY of the stilbene mixture
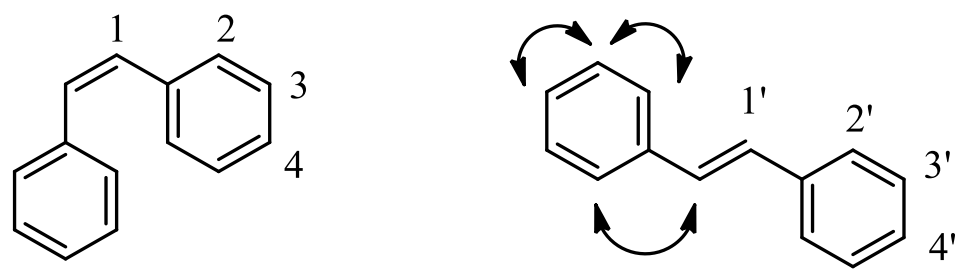

Number of scans $=8$, mixing time $=400 \mathrm{~ms}$, relaxation delay $=1.00 \mathrm{~s}$.

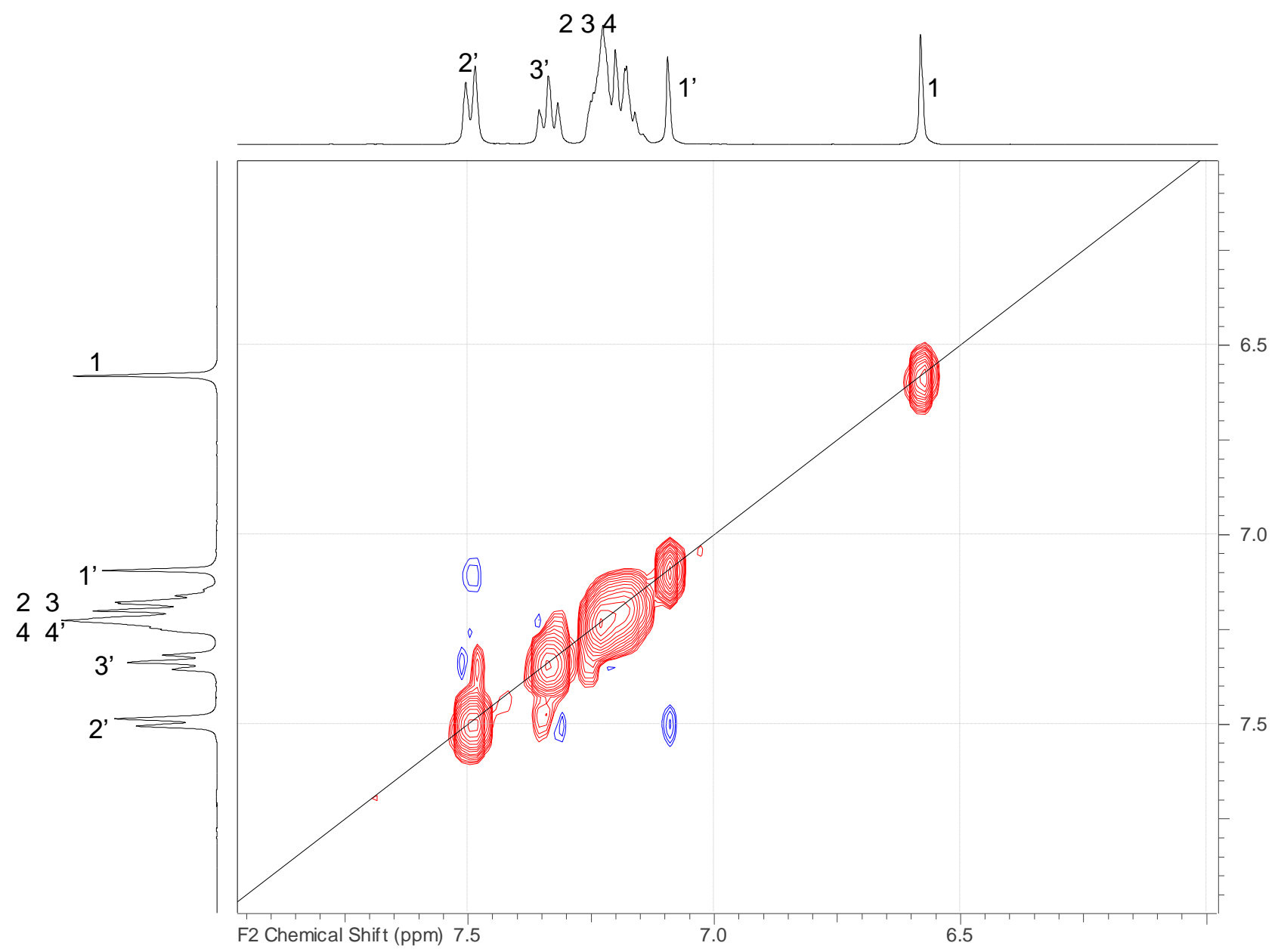


Figure S38. (E/Z)-benzyl 2-(1-methylpyrrolidin-2-ylidene)-2-phenylacetate.
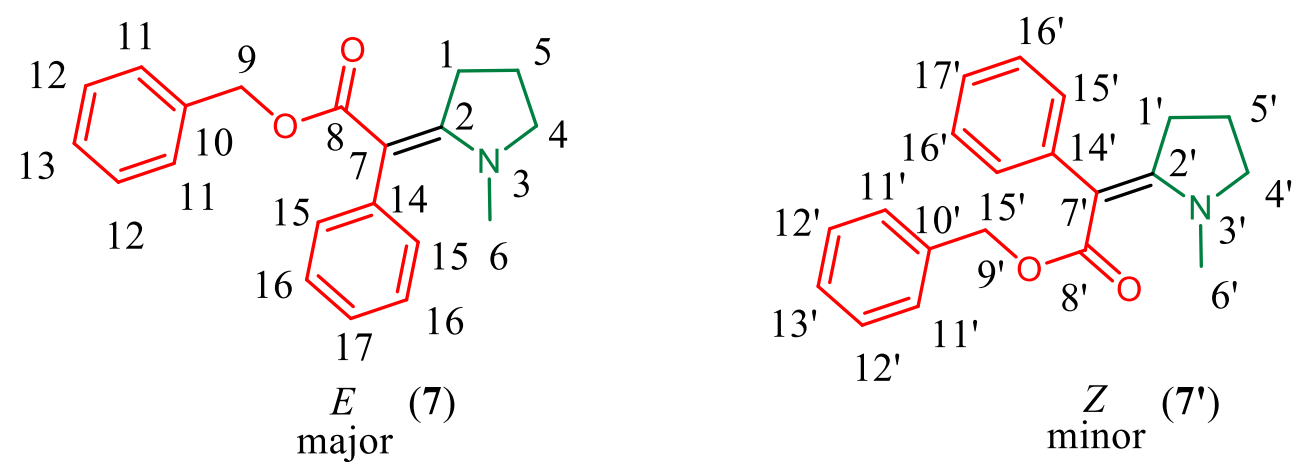

Table S4. In $\mathrm{CDCl}_{3}(E / Z$ 17.6:1)

\begin{tabular}{|c|c|c|c|c|c|}
\hline Position & $\delta \mathrm{C}$ (major, 7) & $\begin{array}{c}\delta \mathrm{H} \text { (major, 7) } J \\
\text { in Hz }\end{array}$ & Position & $\delta \mathrm{C}$ (minor, 7') & $\begin{array}{c}\delta \mathrm{H} \text { (minor, 7') } \\
J \text { in Hz }\end{array}$ \\
\hline 1 & 35.6 & $3.26, \mathrm{t}(7.6)$ & $1^{\prime}$ & & $2.43-2.37, \mathrm{~m}$ \\
\hline 2 & 163.6 & & & & \\
\hline 4 & 56.9 & $3.30, \mathrm{t}(7.2)$ & $4^{\prime}$ & & $3.55-3.40, \mathrm{~m}$ \\
\hline 5 & 21.5 & $1.94, \mathrm{tt}(7.2,7.6)$ & $5^{\prime}$ & & $3.08, \mathrm{~s}, \mathrm{~m}$ \\
\hline 6 & 37.6 & $2.26, \mathrm{~s}$ & $6^{\prime}$ & & \\
\hline 7 & 95.1 & & $7^{\prime}$ & & \\
\hline 8 & 169.4 & & $8^{\prime}$ & & \\
\hline 9 & 64.6 & $5.08, \mathrm{~s}$ & $9^{\prime}$ & & \\
\hline 10 & 138.1 & & $10^{\prime}$ & & \\
\hline 11 & 127.2 & $7.21-7.15, \mathrm{~m}$ & 11 & & \\
\hline $\begin{array}{c}12-17 \\
\text { (excluding } \\
14)\end{array}$ & 132.7 & $7.21-7.15, \mathrm{~m}$ & & & \\
\hline $\begin{array}{c}12-17 \\
\text { (excluding } \\
14)\end{array}$ & 128.2 & $7.21-7.15, \mathrm{~m}$ & & & \\
\hline $\begin{array}{c}12-17 \\
\text { (excluding } \\
14)\end{array}$ & 127.5 & $7.21-7.15, \mathrm{~m}$ & & & \\
\hline $\begin{array}{c}12-17 \\
\text { (excluding } \\
14)\end{array}$ & 125.8 & $7.21-7.15, \mathrm{~m}$ & & & \\
\hline 14 & & & & & \\
\hline
\end{tabular}


Figure S39. ${ }^{1} \mathrm{H}$ NMR of the mixture of 7 and 7'

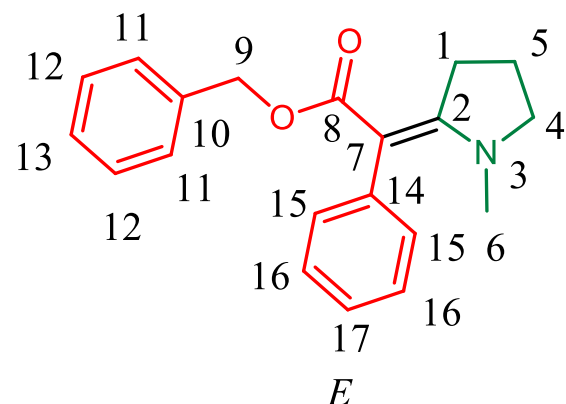

major

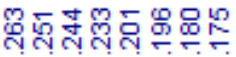

MNMm的

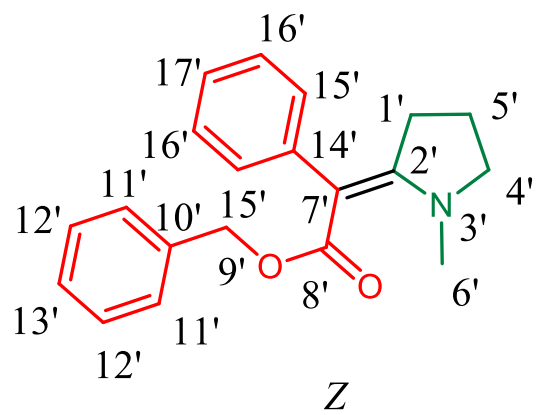

minor

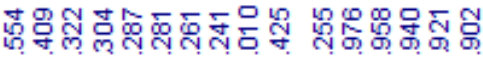

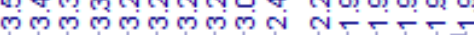

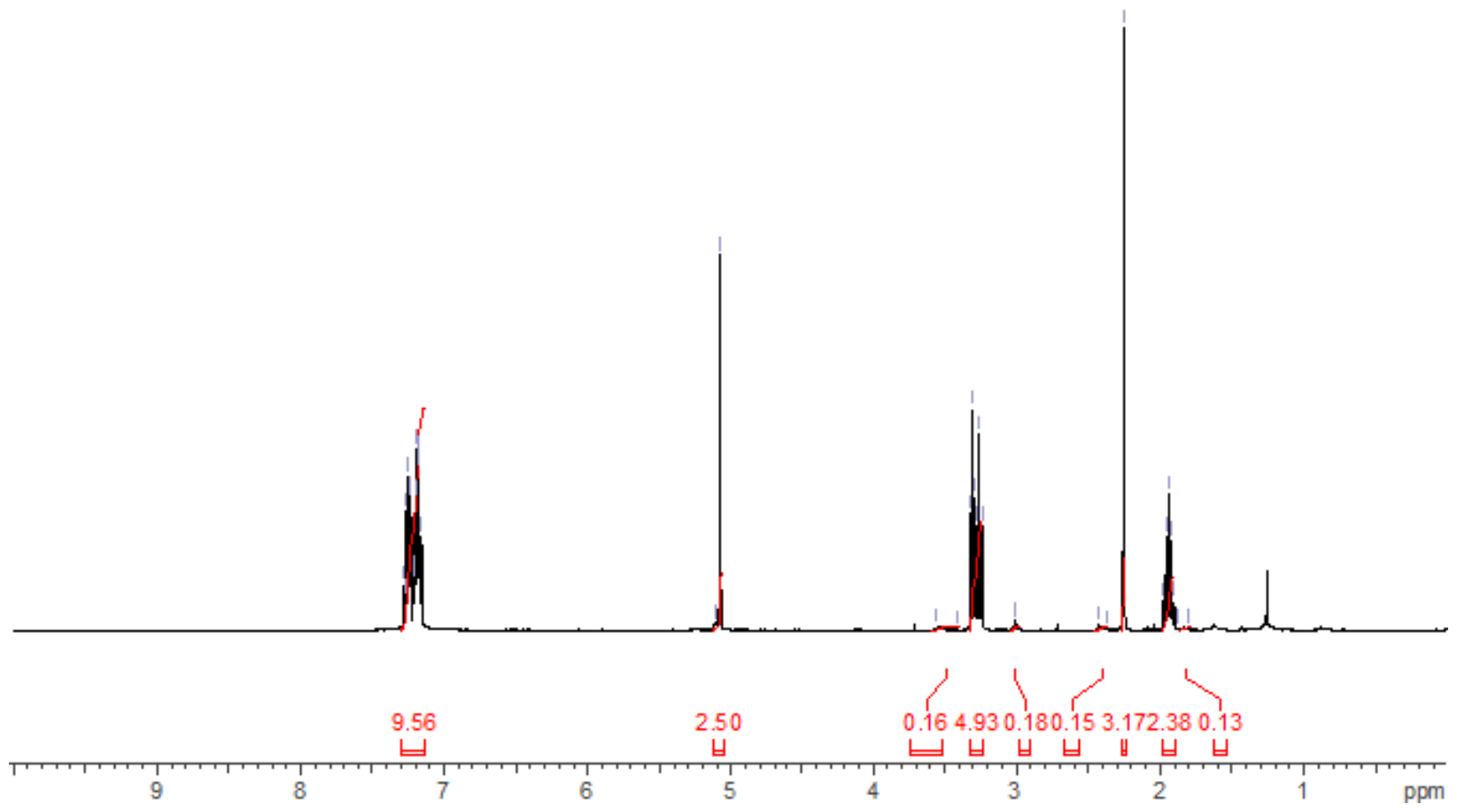


Figure S40. ${ }^{13} \mathrm{C}$ NMR of the mixture of 7 and 7 ,
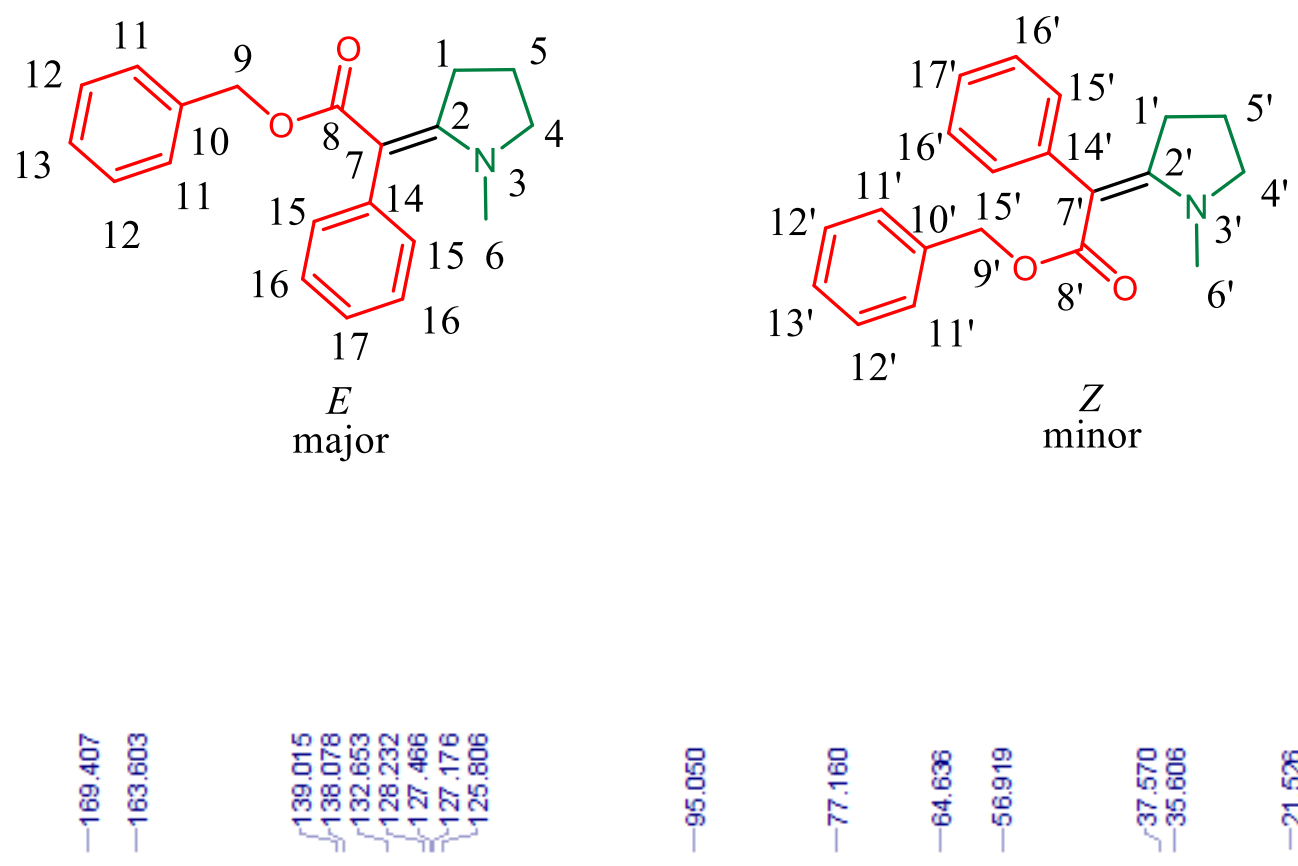

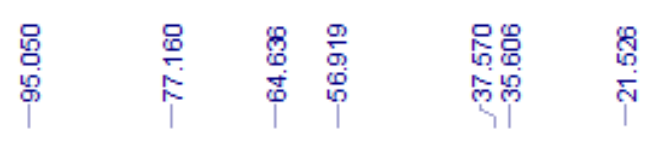

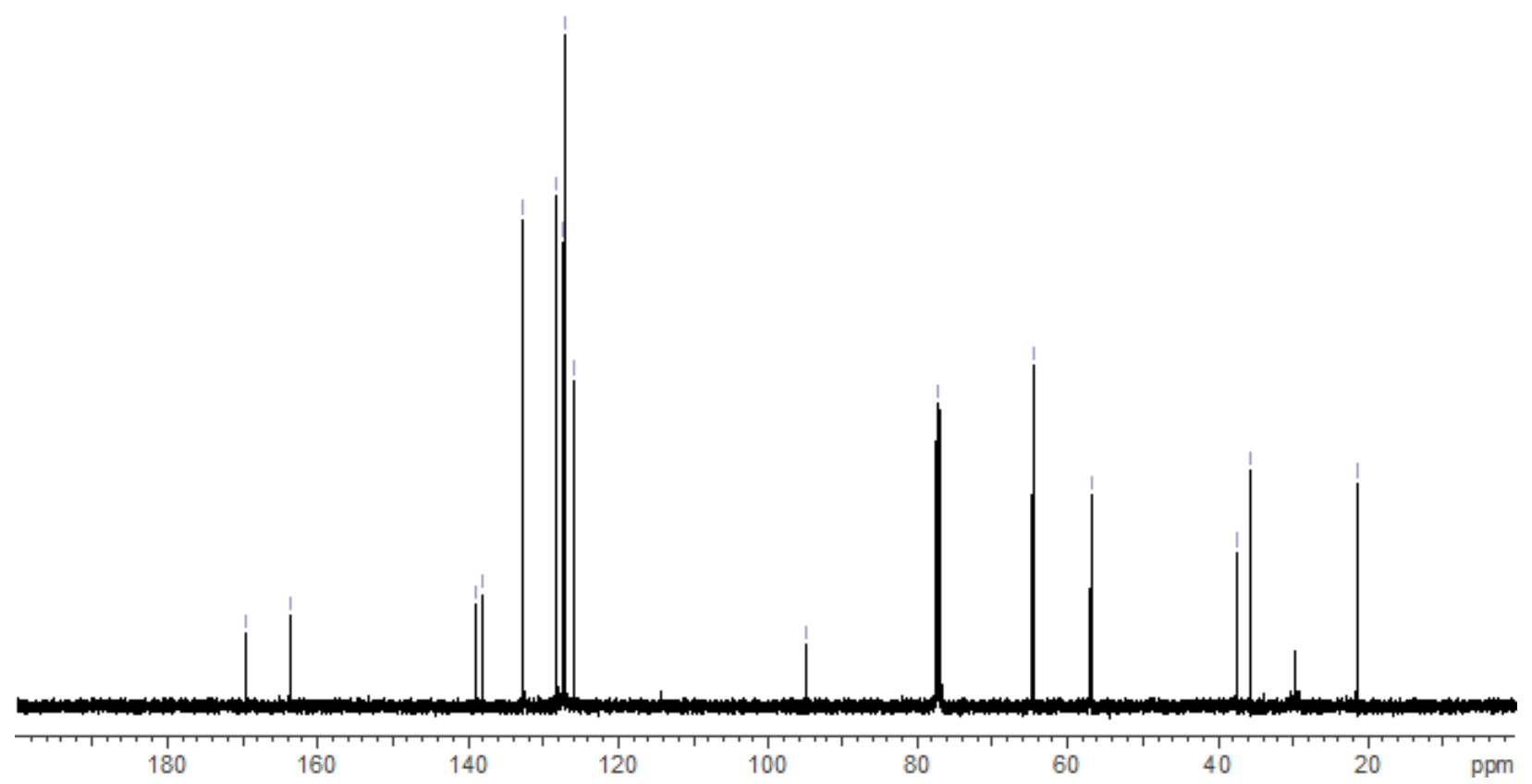




\section{Confirmation of $E / Z$ isomerization}

The four conformations of the compounds that may provide different NMR signals are shown below. Either conformation of the $E$ isomer may show NOEs between the $\mathrm{C}(6)$ hydrogens and the phenyl ring, but it should not show NOEs between $\mathrm{C}(6)$ hydrogens and the benzylic hydrogen atoms. On the other hand, either conformation of the $Z$ isomer may show NOEs between the $\mathrm{C}\left(1^{\prime}\right)$ protons and the aromatic hydrogen atoms. Either conformation of the $\mathrm{Z}$ isomer should not show NOEs between $\mathrm{C}\left(1^{\prime}\right)$ and the benzylic protons.

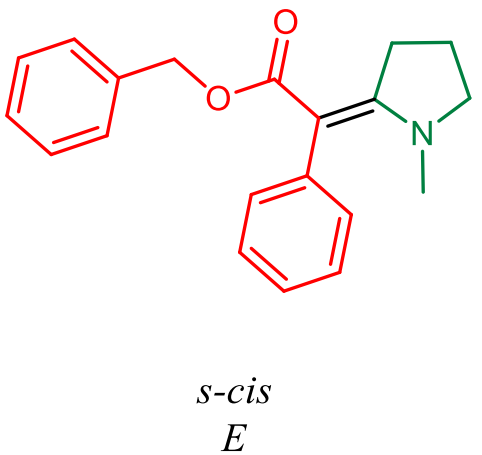

E<smiles>CN1CCCC1=C(C(=O)OCc1ccccc1)c1ccccc1</smiles>

$s$-cis

$Z$<smiles>CN1CCC/C1=C(\C(=O)OCc1ccccc1)c1ccccc1</smiles>

s-trans

E

major

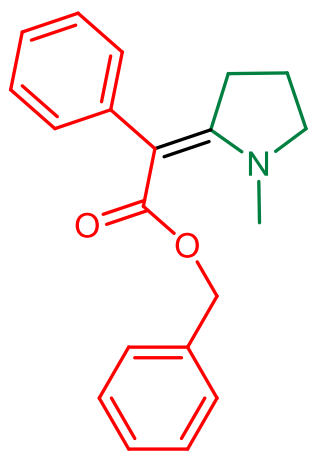

minor s-trans

$Z$

Figure S41. $E$ and $Z$ isomers

Irradiation of $\mathrm{C}(6)$ hydrogens of the major isomer did not result in any NOE enhancements of protons on the benzylic position. It did result in the enhancement of $\mathrm{C}(4)$ hydrogens and protons in the aromatic region. Unfortunately, irradiation of the $\mathrm{C}\left(1^{\prime}\right)$ hydrogens of the minor isomer did not result in any enhancement of the aromatic protons. We attribute this to the low concentration of the minor isomer, which results in a weak signal. Irradiation of $C\left(6^{\prime}\right)$ did not show any enhancement of aromatic proton signals, providing support to the suggested $E / Z$ isomerization. However, this is not decisive evidence. Fortunately, during the irradiation experiment, a minor rotational isomer (s-cis or s-trans of the $\mathrm{Z}$ isomer) could be observed as a 
-ve peak (-19\%) close to the irradiated peak (NOESY on S40). This evidence provides further confidence that the peak assignments in the table belong to $E / Z$ isomers and not to s-cis/s-trans type of isomers.

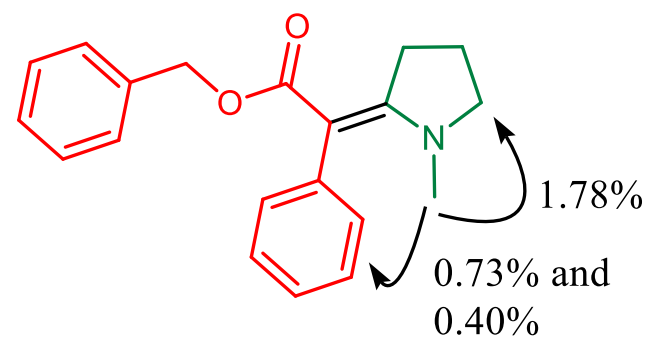

$s-c i s$

E

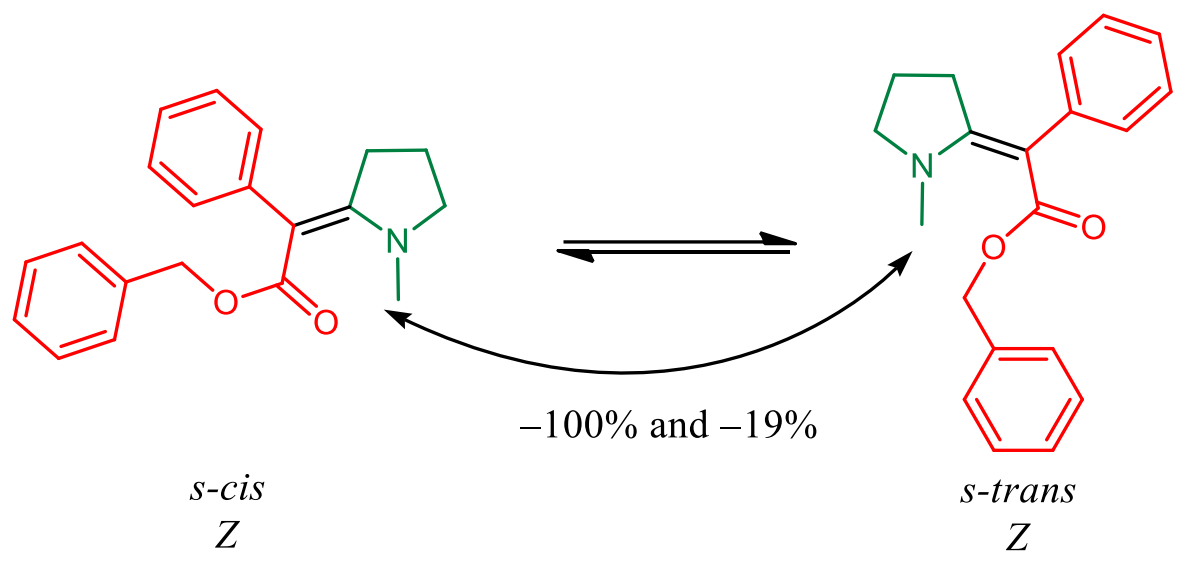

Figure S42. Selected 1D-NOESY data of $E$ and $Z$ isomers

We also prepared compound (8) and compared the $\mathrm{N}-\underline{\mathrm{CH}}_{3}$ and the $\mathrm{NCC}_{2}{ }_{2}^{1} \mathrm{H}-\mathrm{NMR}$ chemical shifts of $\mathbf{8}$ with $\mathbf{7}$ and 7'. The anisotropic effect of the carbonyl function is expected to deshield the $\mathrm{NCCH}_{2}$ and $\mathrm{N}-\mathrm{CH}_{3}$ protons, ${ }^{1}$ while the phenyl group can cause shielding of these protons. ${ }^{2-3}$ The $\mathrm{NCH}_{3}$ chemical shift of $(\mathbf{8})$ is close to the chemical shift of the minor isomer ( $\left.7^{\prime}\right)$, while the $\mathrm{NCCH}_{2}$ chemical shift of $(\mathbf{8})$ is close to the $\mathrm{NCCH}_{2}$ chemical shift of the major isomer (7). The similarity of these chemical shift values of $\mathbf{8}$ with $\mathbf{7}$ and $\mathbf{7}$ ' suggests that the $\mathbf{7} \rightarrow \mathbf{7}$ ' isomerization is not due to the $s$-cis $\rightarrow s$-trans type of isomerization, but due to $E \rightarrow Z$ isomerization.<smiles>[R6]C1CCN([Z20])C1=C(C(=O)OCc1ccccc1)c1ccccc1</smiles>

major (7)

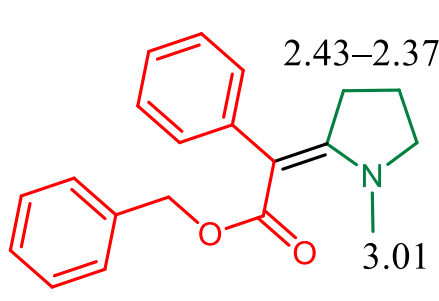

minor $\left(7^{\prime}\right)$<smiles>[Y16]N1CCCC1=C(C(=O)OCc1ccccc1)C(=O)OCc1ccccc1</smiles>

(8)

Figure S43. Use of chemical shift values of (8) for the selection of structures 7 and 7', 
Other 1-D and 2-D NMR spectra of 7 and 7'

Figure S44. 1-D NOESY of compound

Number of scans $=512$, mixing time $=500 \mathrm{~ms}$, relaxation delay $=1.00 \mathrm{~s}$.

Irradiation at $2.26 \mathrm{ppm}$

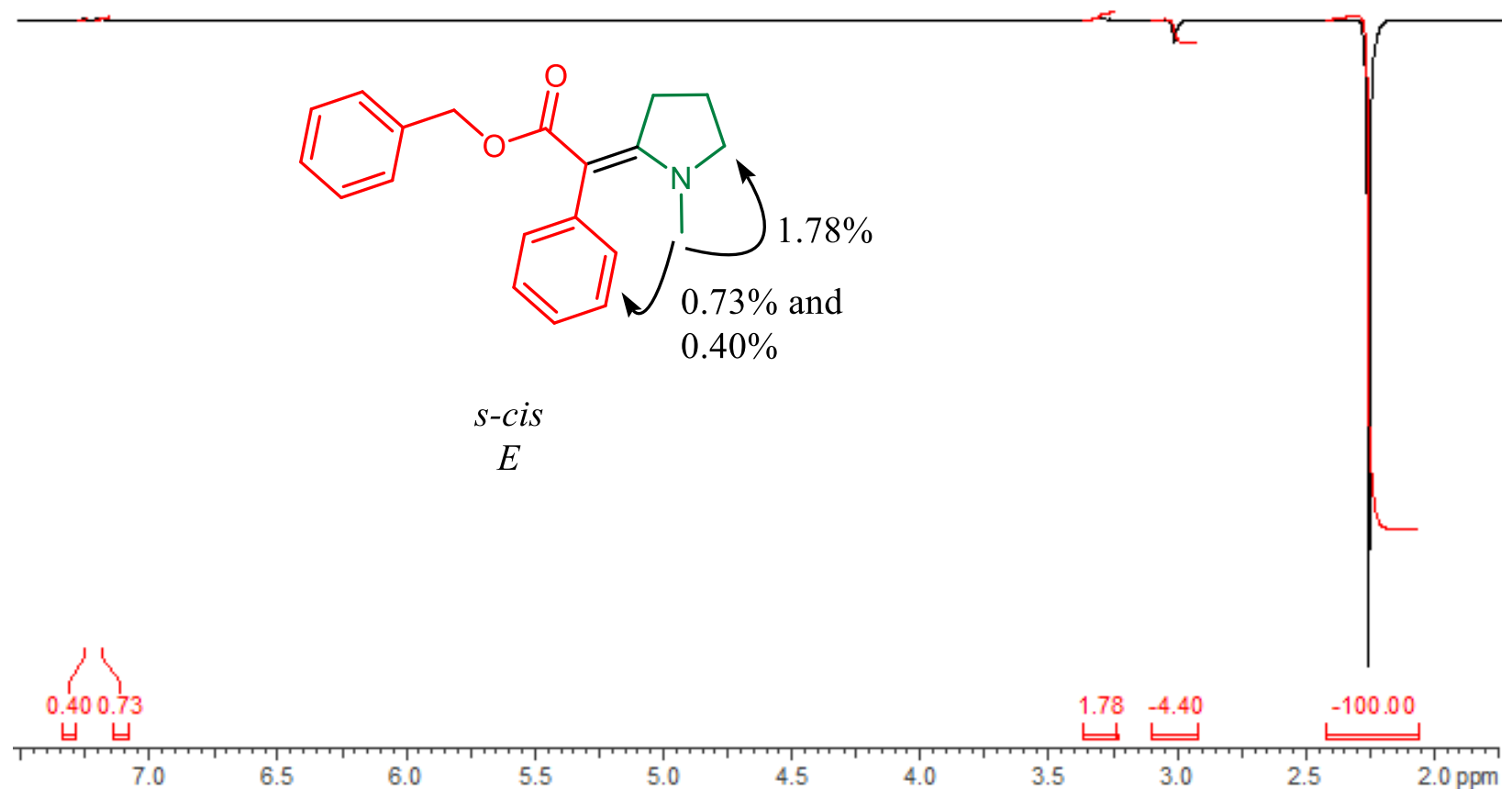




\section{Figure S45. 1-D NOESY of 7 and 7'}

Number of scans $=20000$, mixing time $=500 \mathrm{~ms}$, relaxation delay $=1.00 \mathrm{~s}$.

Irradiation at $3.01 \mathrm{ppm}$

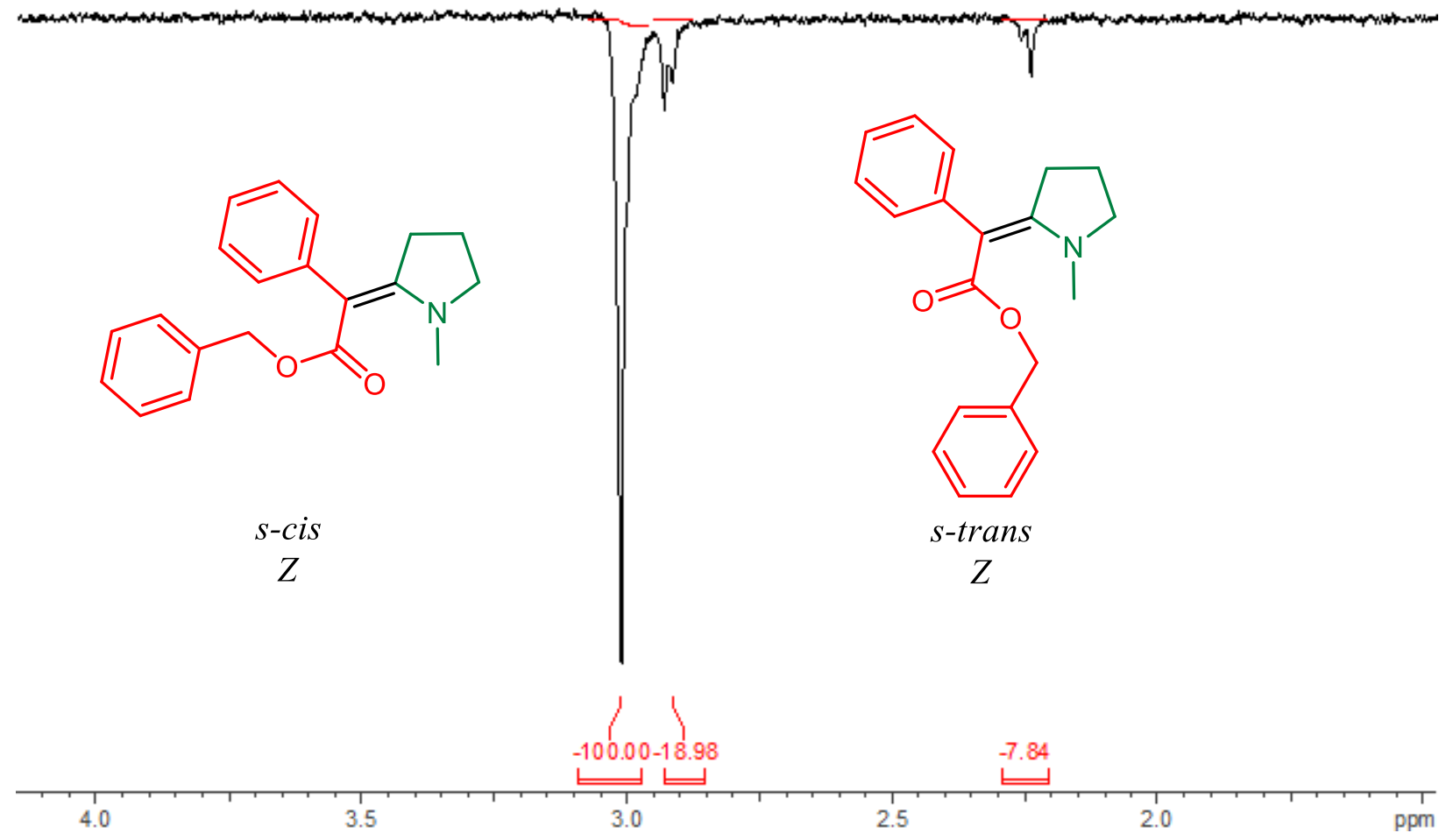




\section{Figure S46. 2D-NOESY spectrum of 7 and 7 '}

Number of scans $=8$, mixing time $=400 \mathrm{~ms}$, relaxation delay $=1.00 \mathrm{~s}$.

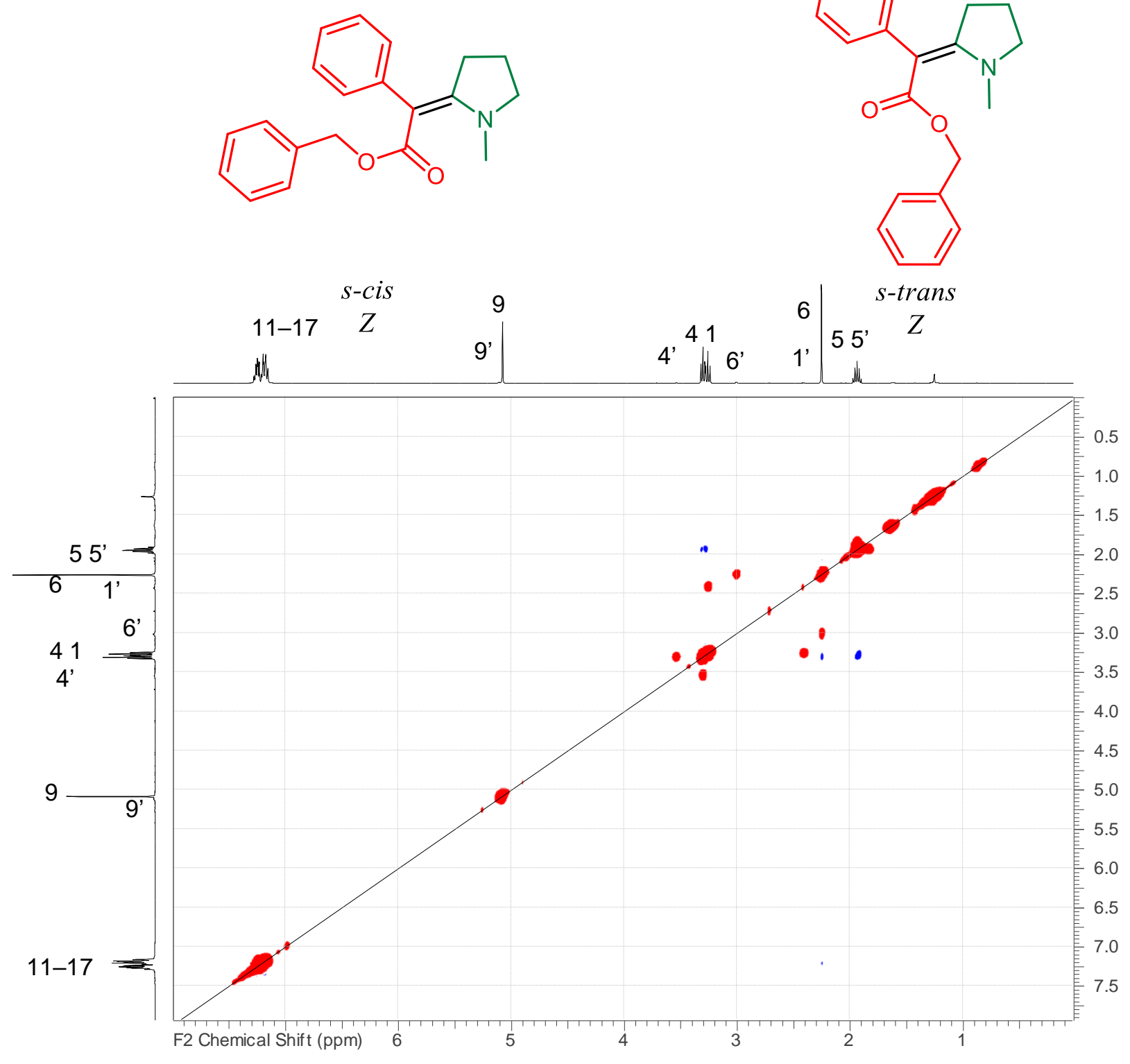


Figure S47. ${ }^{1} \mathrm{H}-{ }^{1} \mathrm{H}$ DQF-COSY spectrum of 7 and 7',
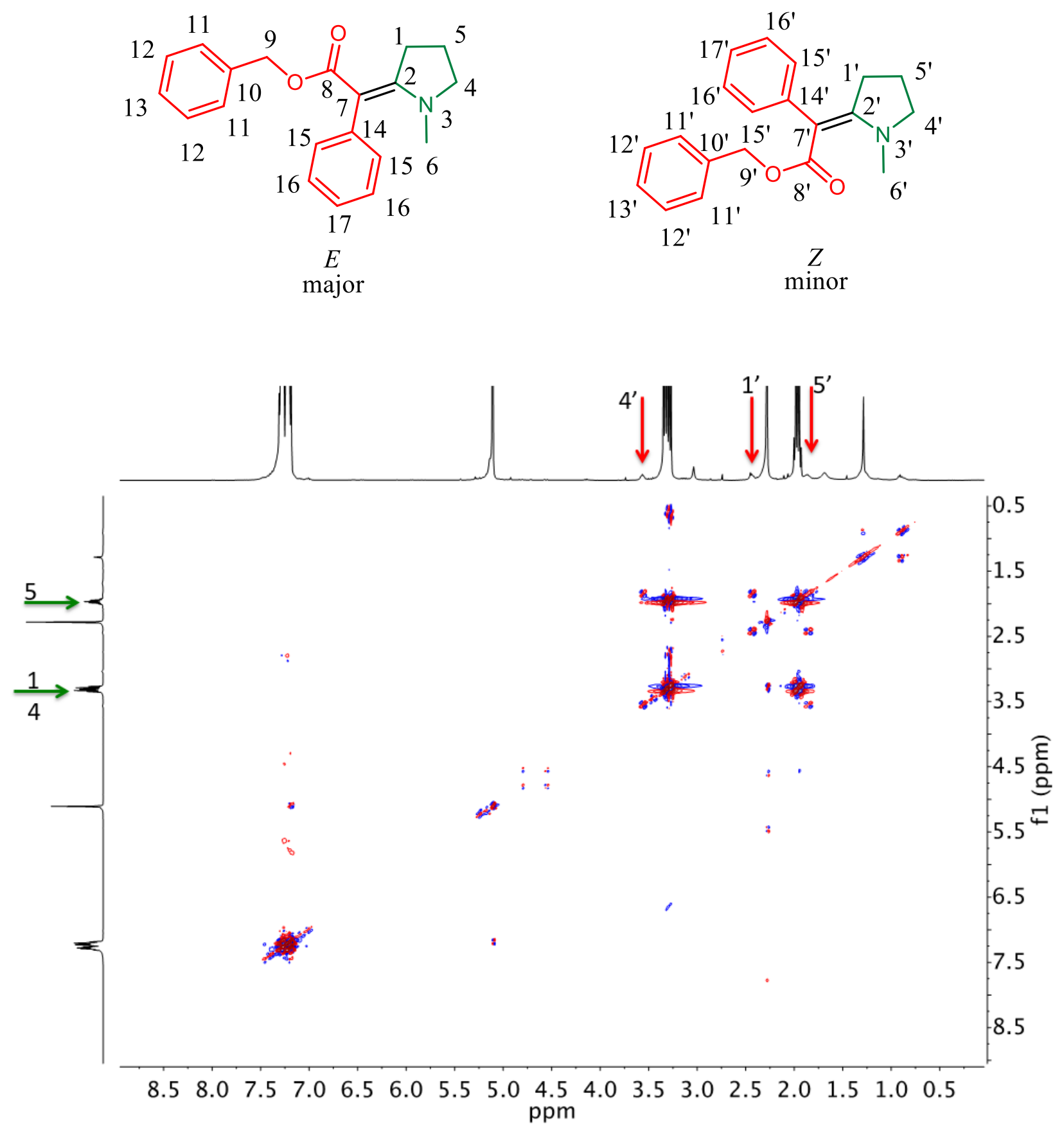
Figure S48. HSQC spectrum of 7 and 7'

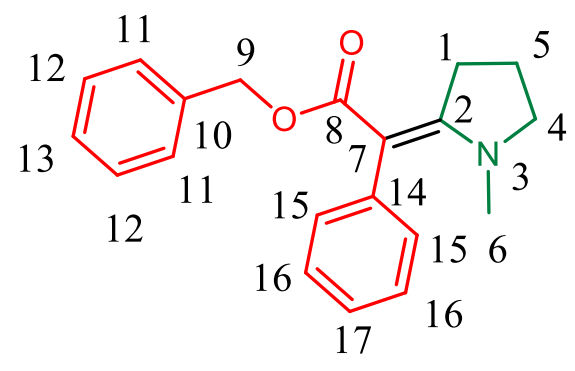

E

major

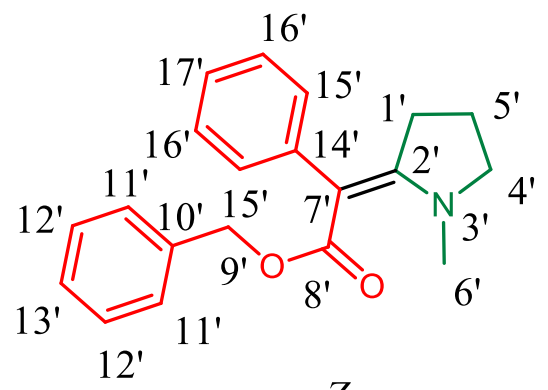

$\underset{\text { minor }}{Z}$

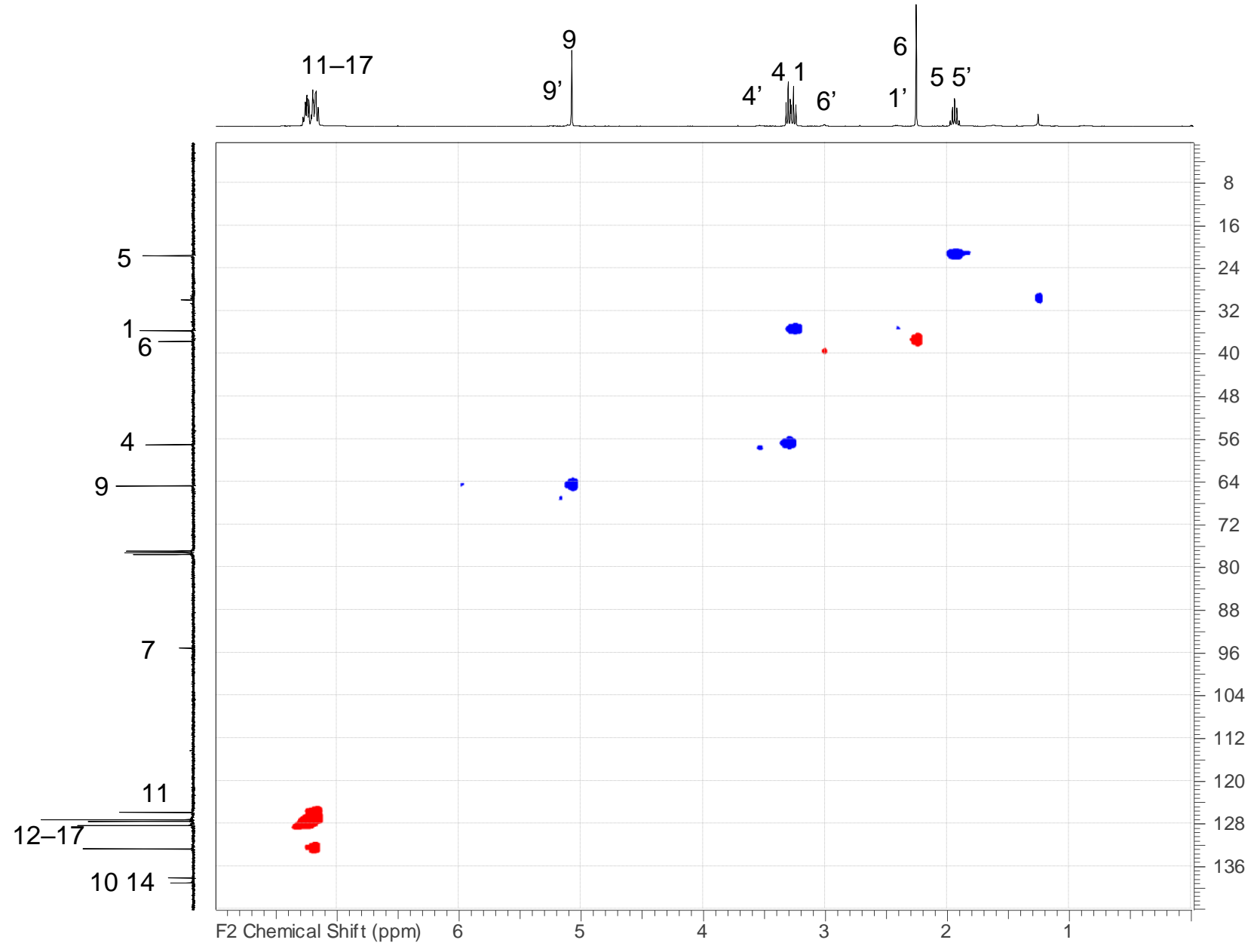


Figure S49. HMBC spectrum of 7 and 7'

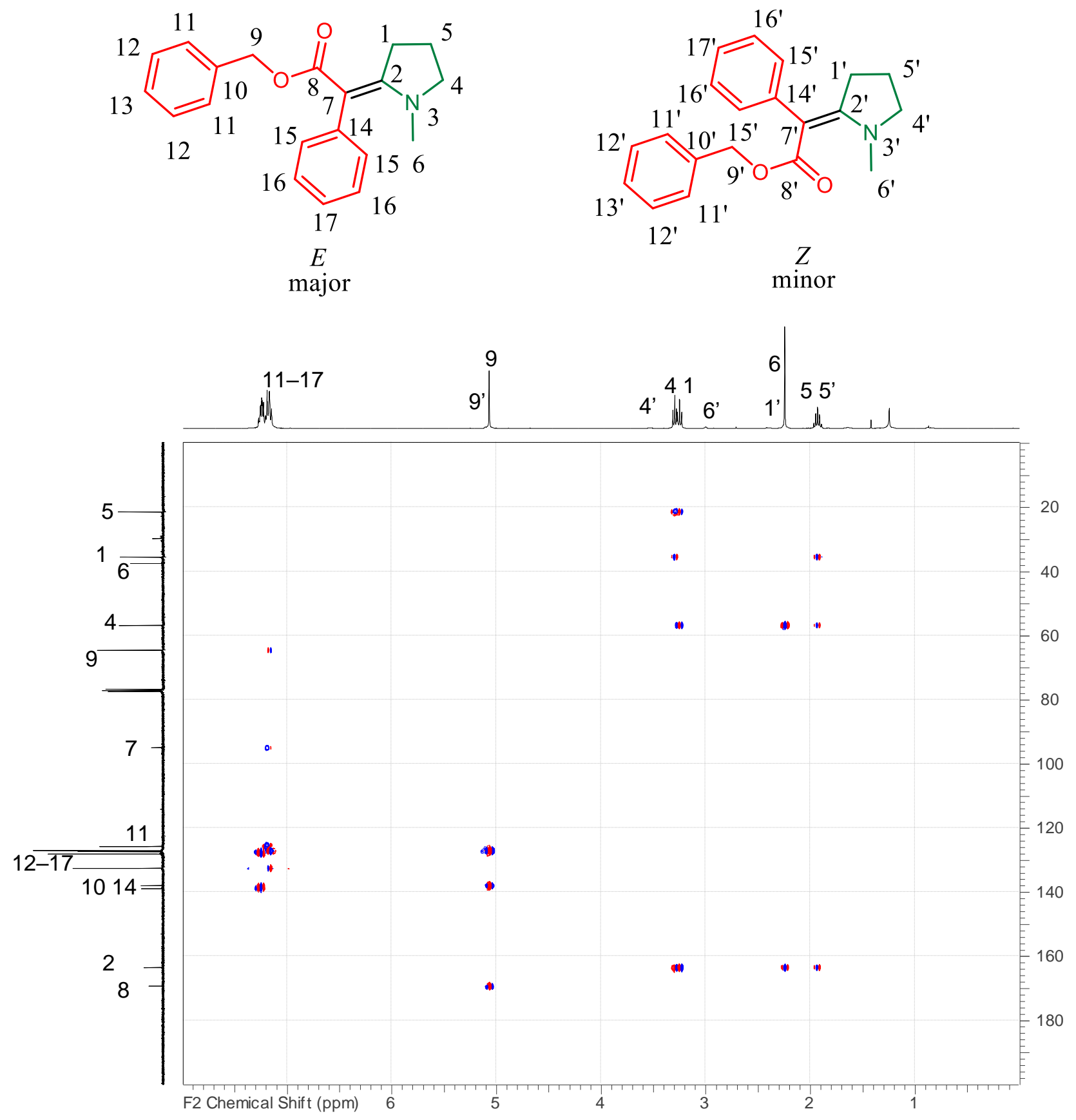


Figure S50. Variable Temperature ${ }^{1} \mathrm{H}-\mathrm{NMR}$ Spectra
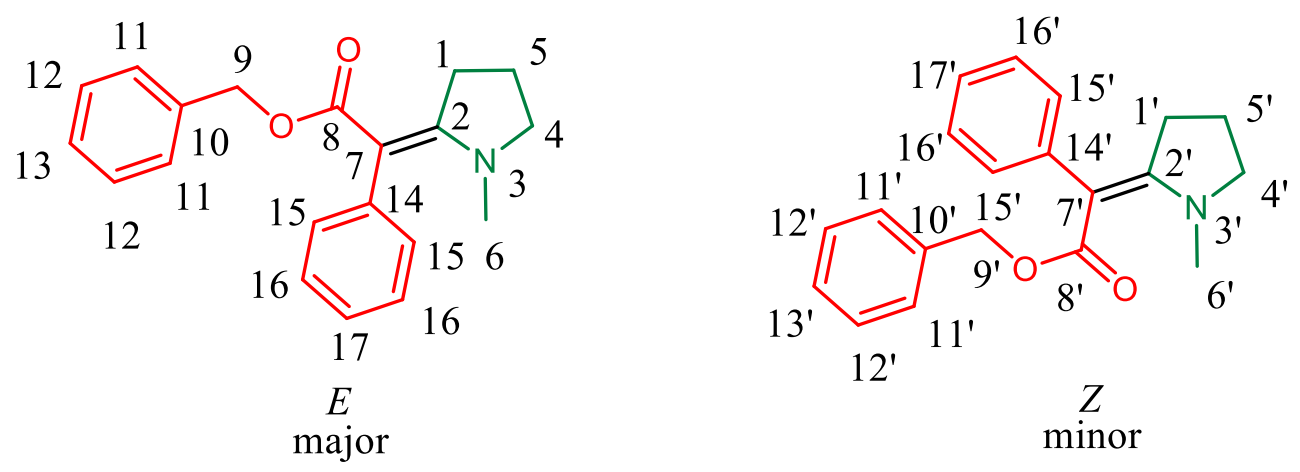

Temperature was calibrated with methanol. Non-calibrated temperatures are reported as "nominal" and calibrated temperatures are reported as "actual."

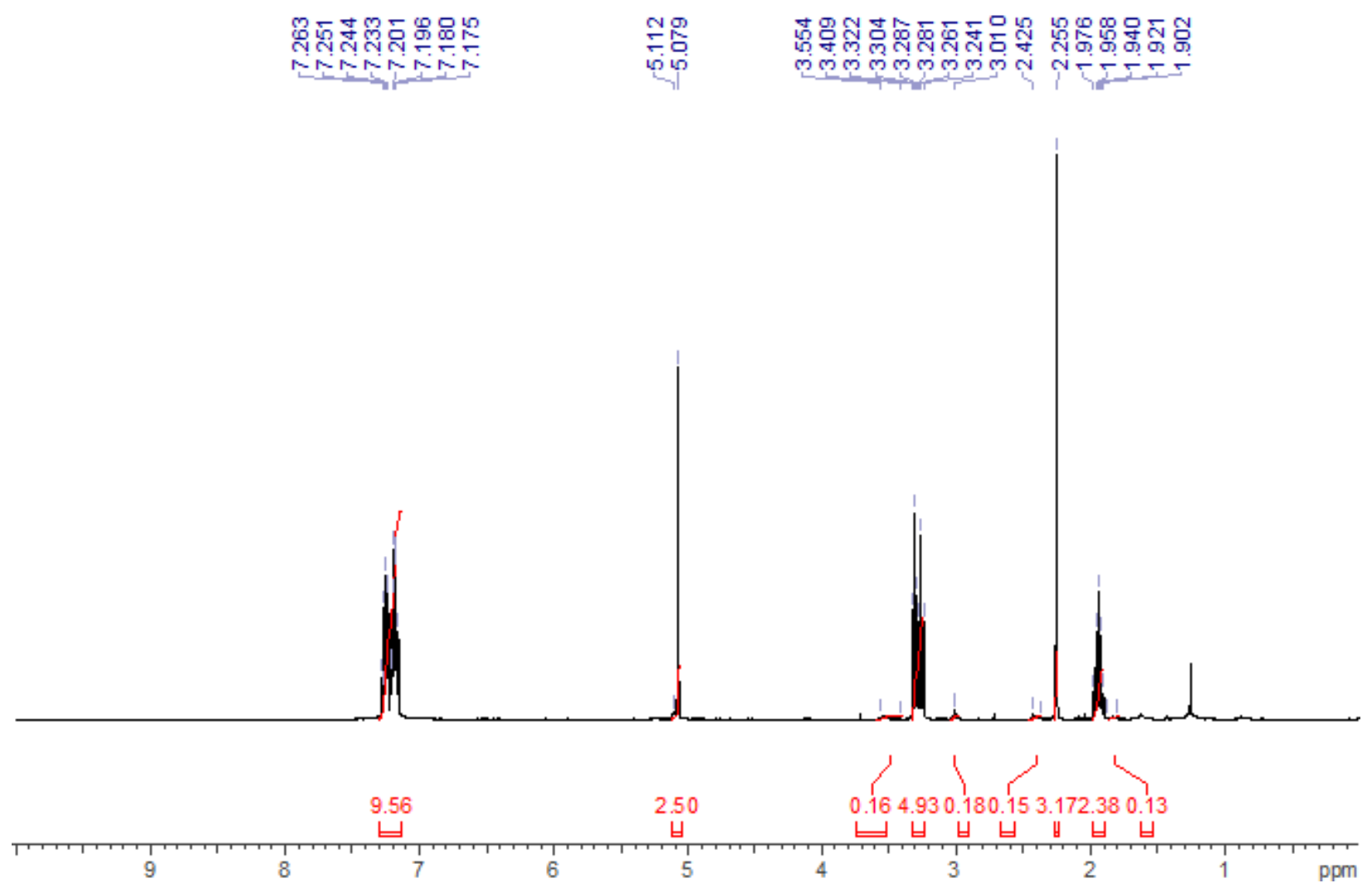


Figure S51. Nominal $10{ }^{\circ} \mathrm{C}$, actual $9.7^{\circ} \mathrm{C}$

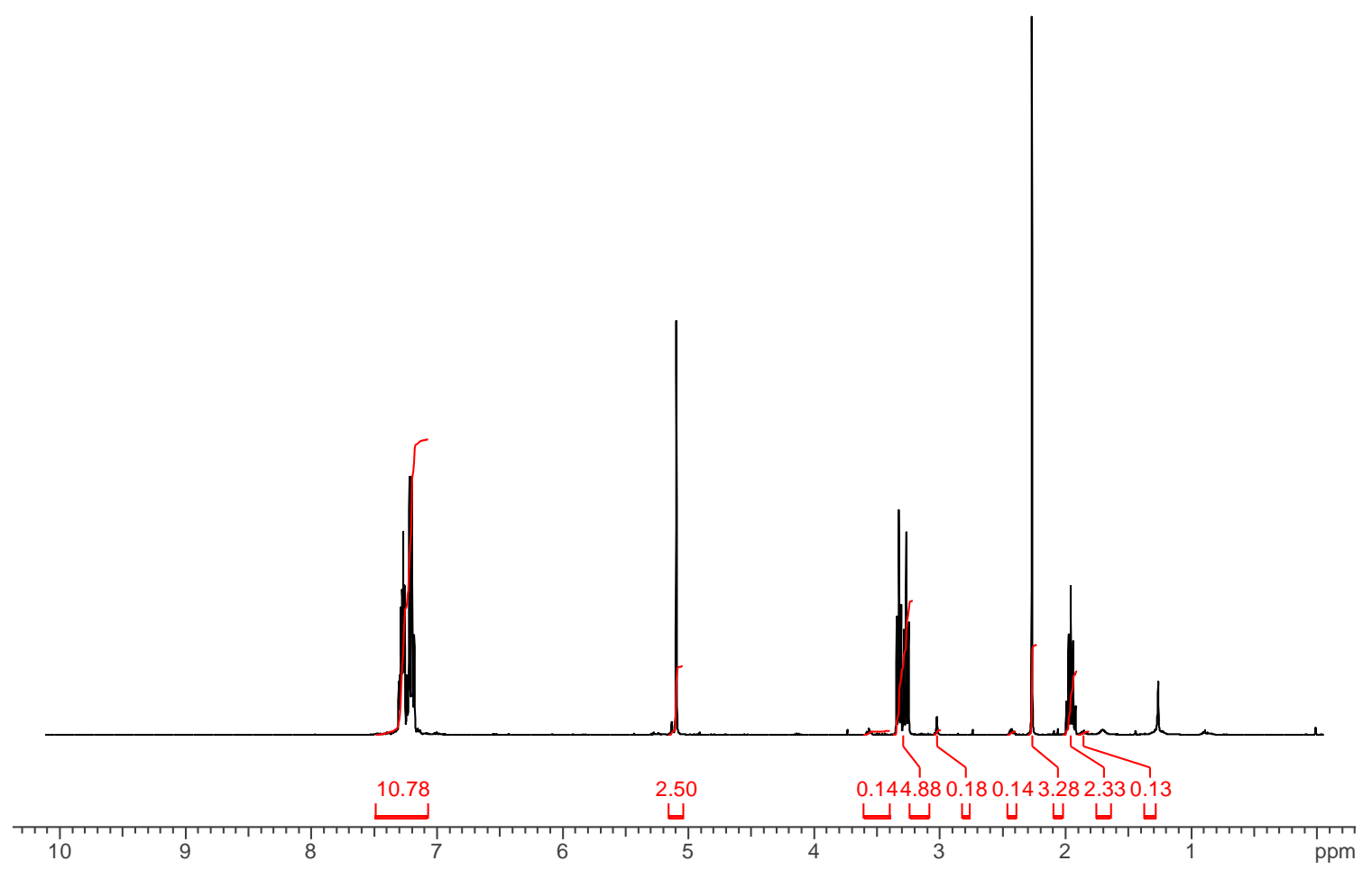

Figure S52. Nominal $0{ }^{\circ} \mathrm{C}$, actual $-0.7^{\circ} \mathrm{C}$

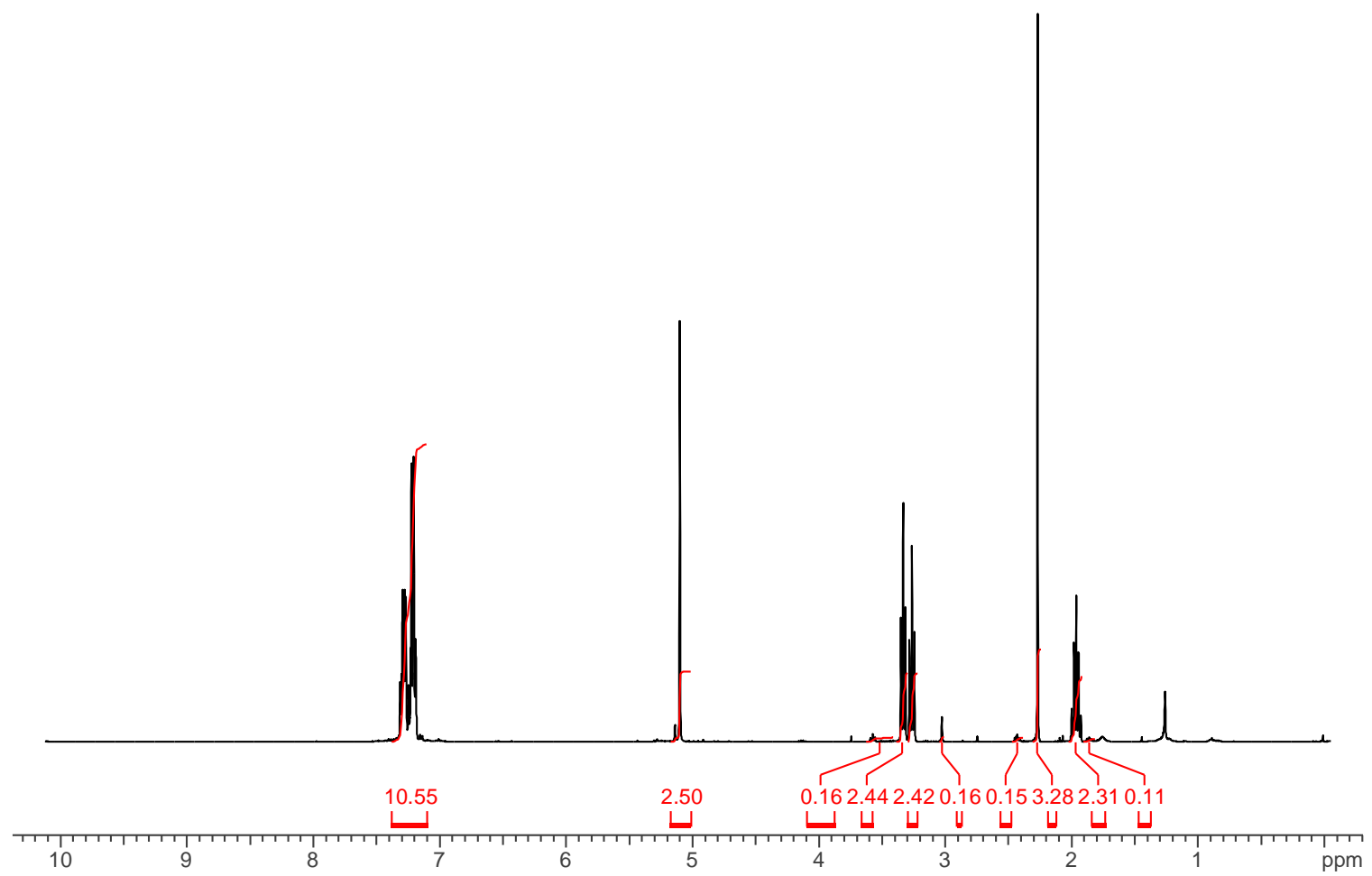


Figure S53. Nominal $-10{ }^{\circ} \mathrm{C}$, actual $-11.0{ }^{\circ} \mathrm{C}$

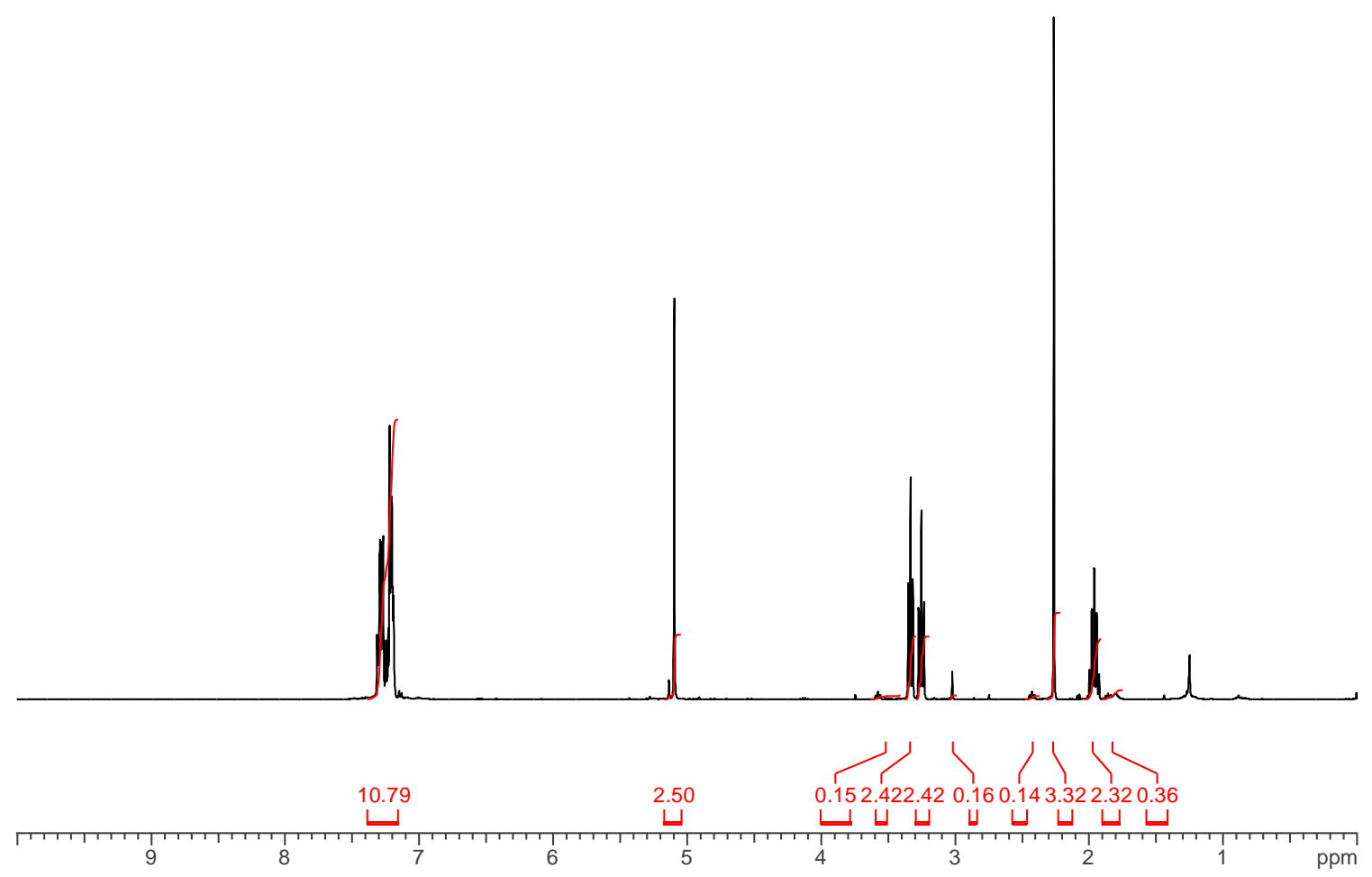

Figure S54. Nominal $-20{ }^{\circ} \mathrm{C}$, actual $-21.4{ }^{\circ} \mathrm{C}$

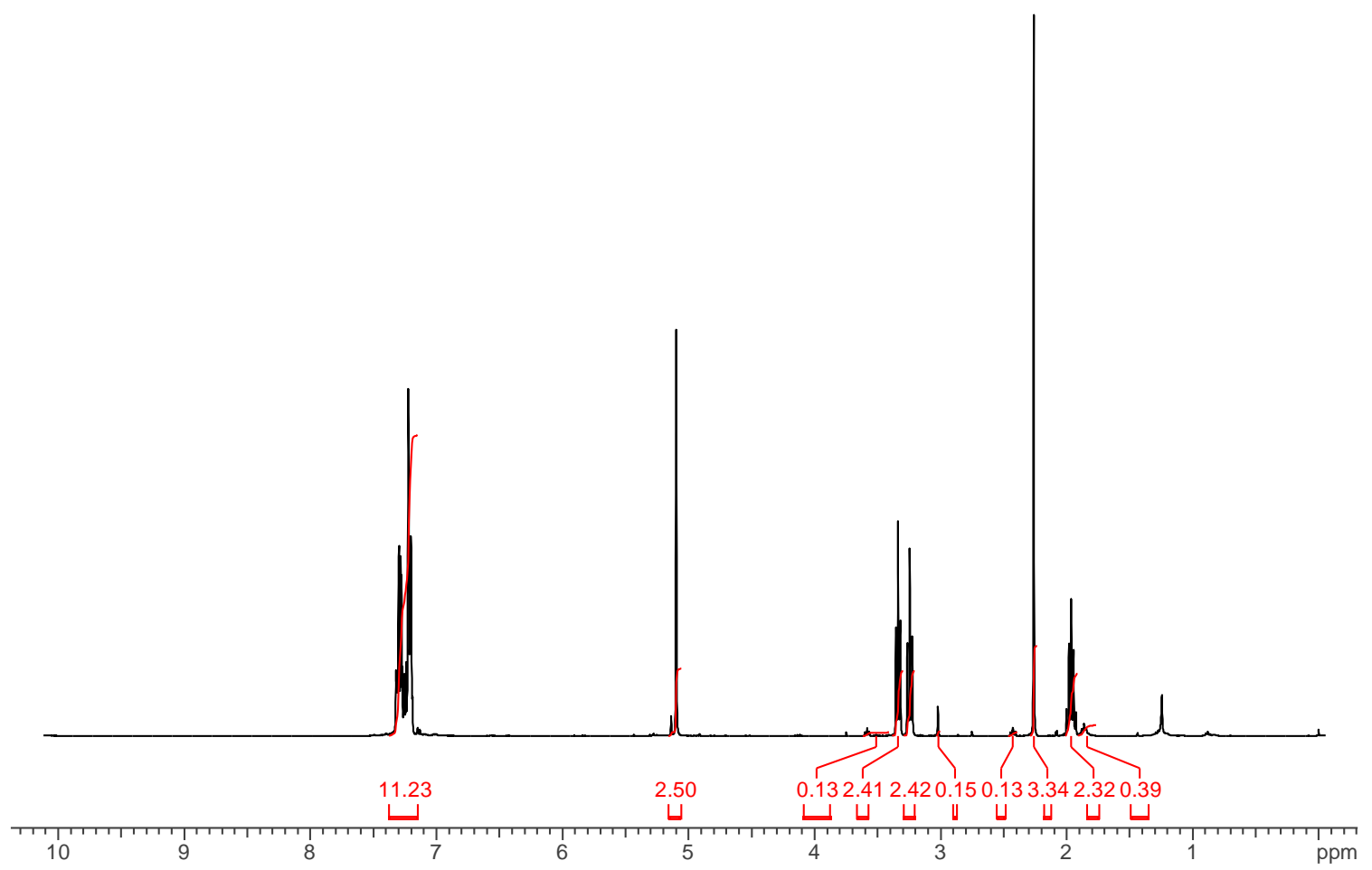


Figure S55. Nominal $-30{ }^{\circ} \mathrm{C}$, actual $-31.8{ }^{\circ} \mathrm{C}$

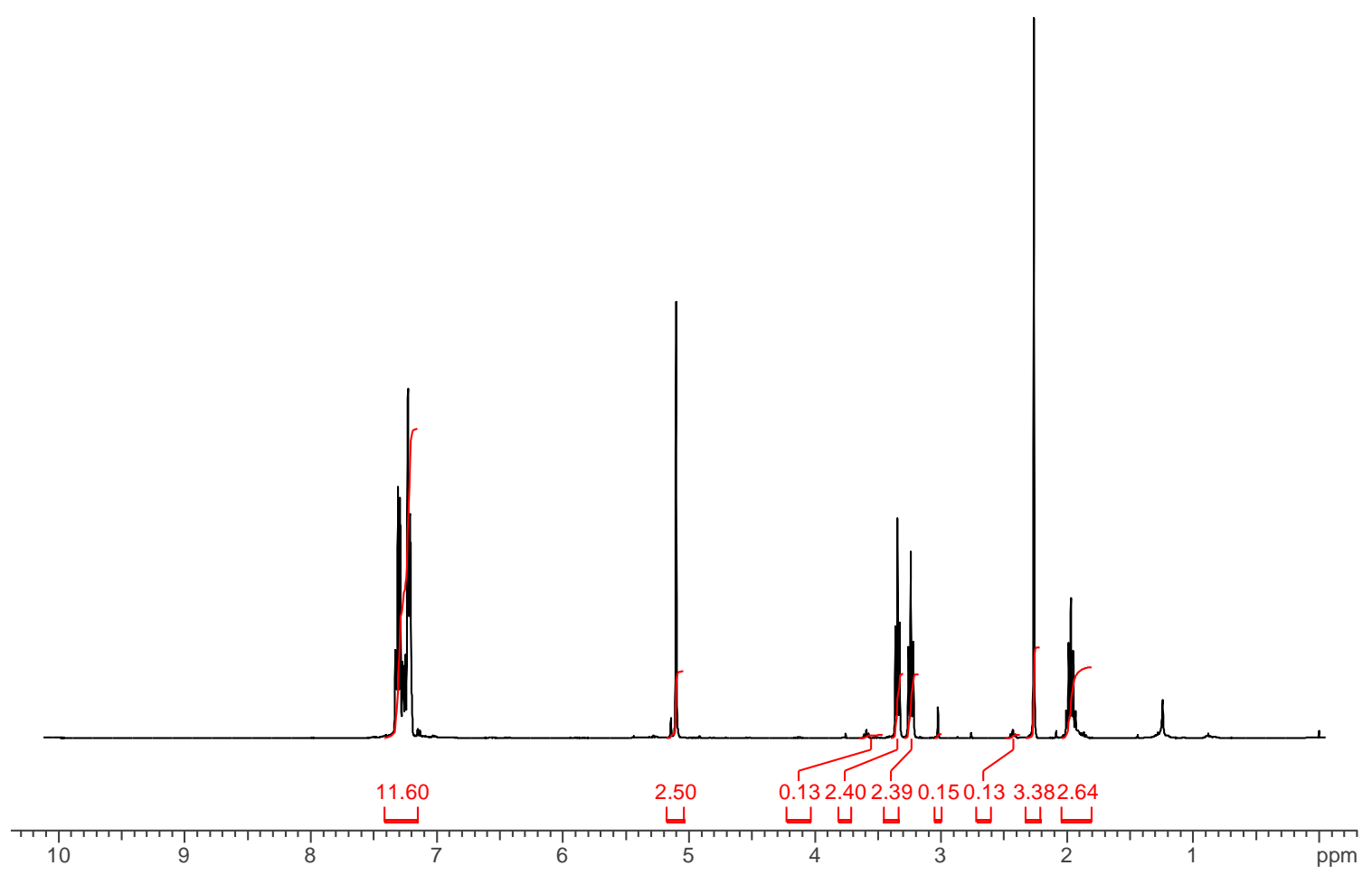

Figure S56. Nominal $-40{ }^{\circ} \mathrm{C}$, actual $-42.2^{\circ} \mathrm{C}$

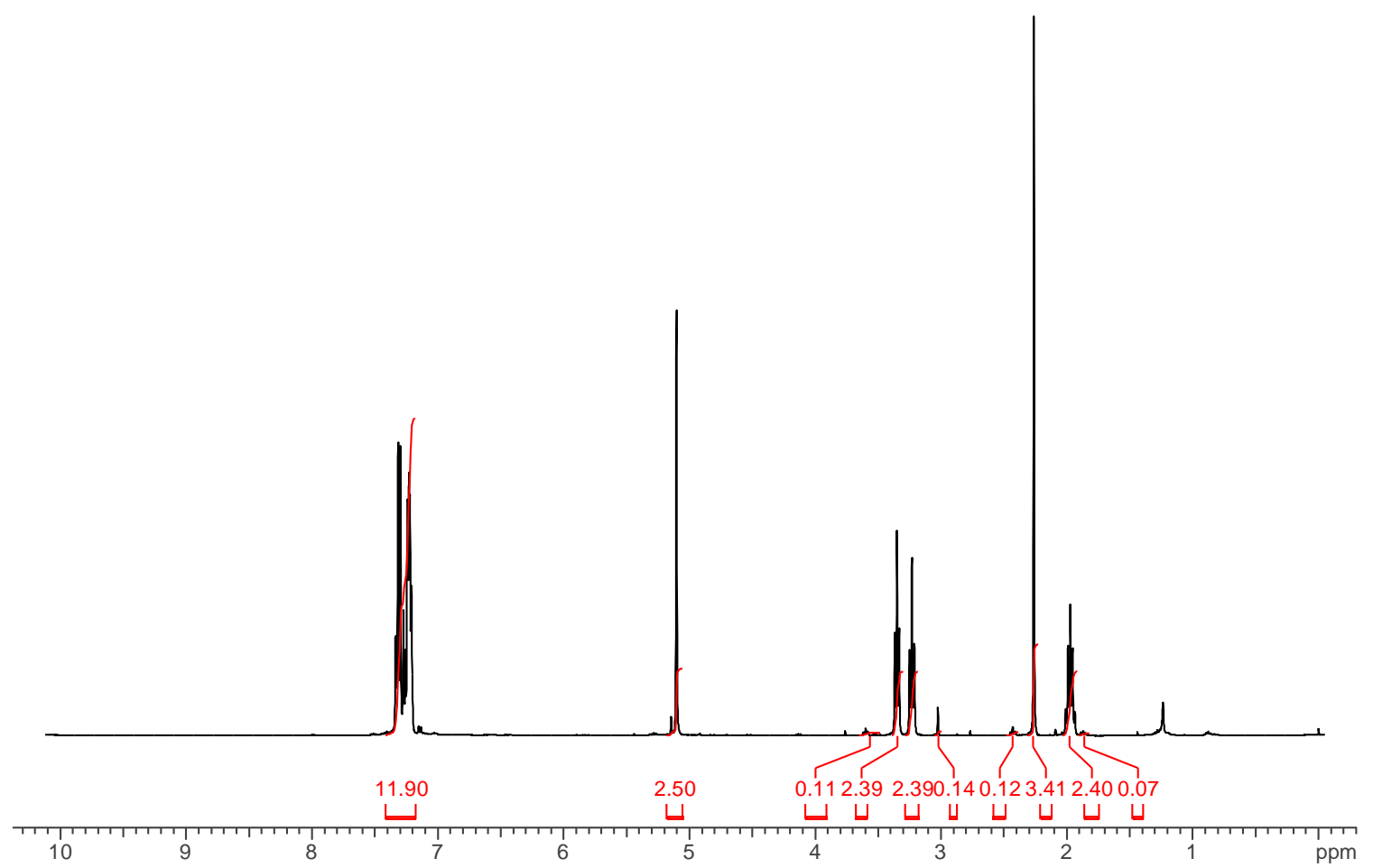


Figure S57. Stacked and expanded VT ${ }^{1} \mathrm{H}$ NMR
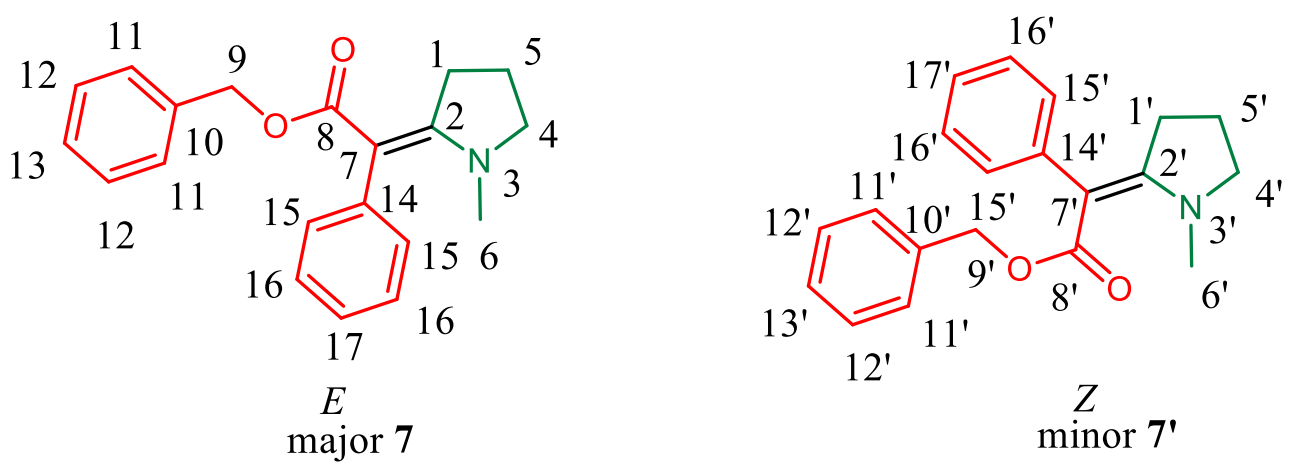

For clarity, only nominal temperatures are shown below.

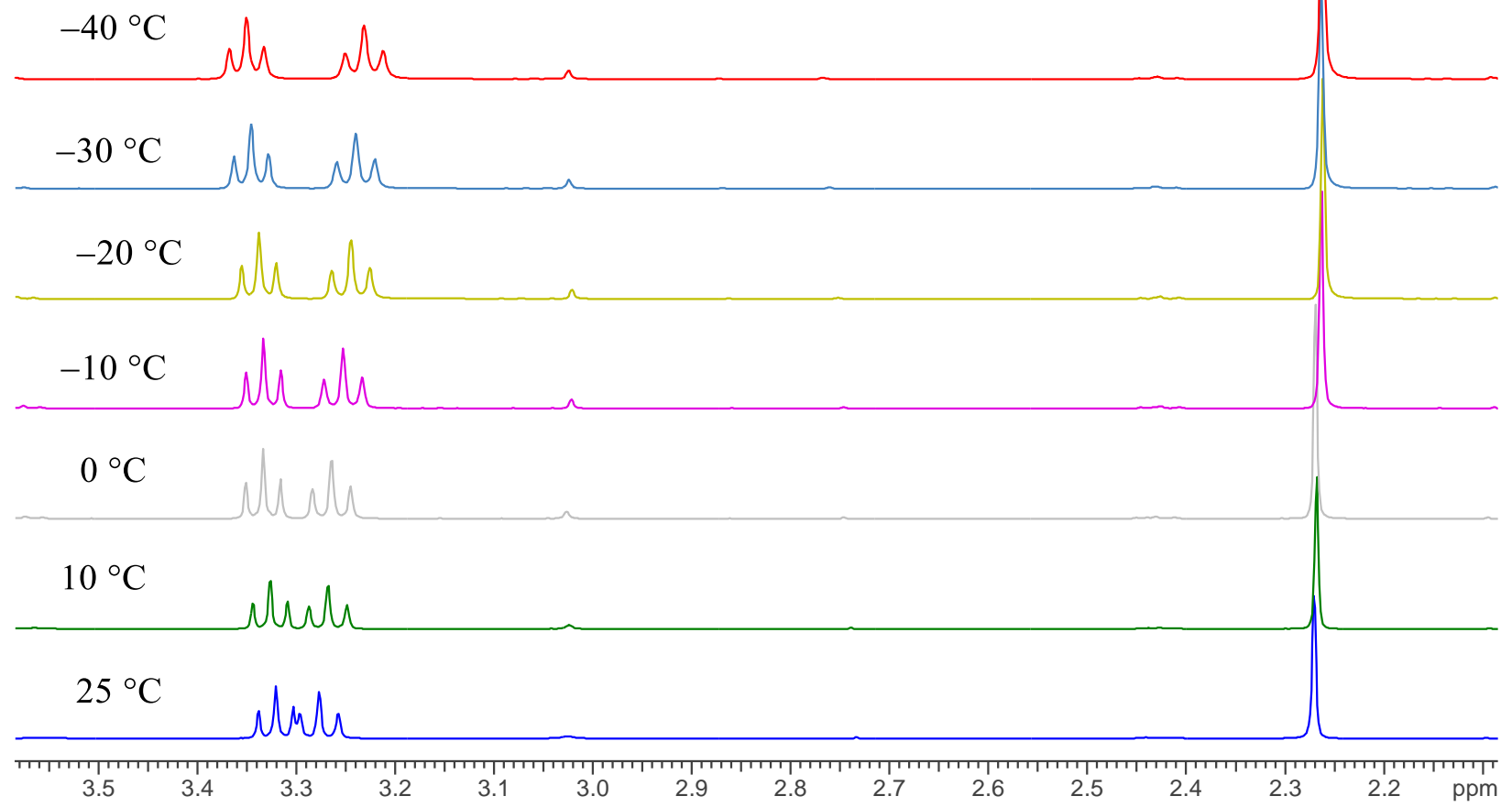


Figure S58. ${ }^{1} \mathrm{H}$ NMR of 8<smiles>CN1CCCC1=C(C(=O)OCc1ccccc1)C(=O)OCc1ccccc1</smiles>

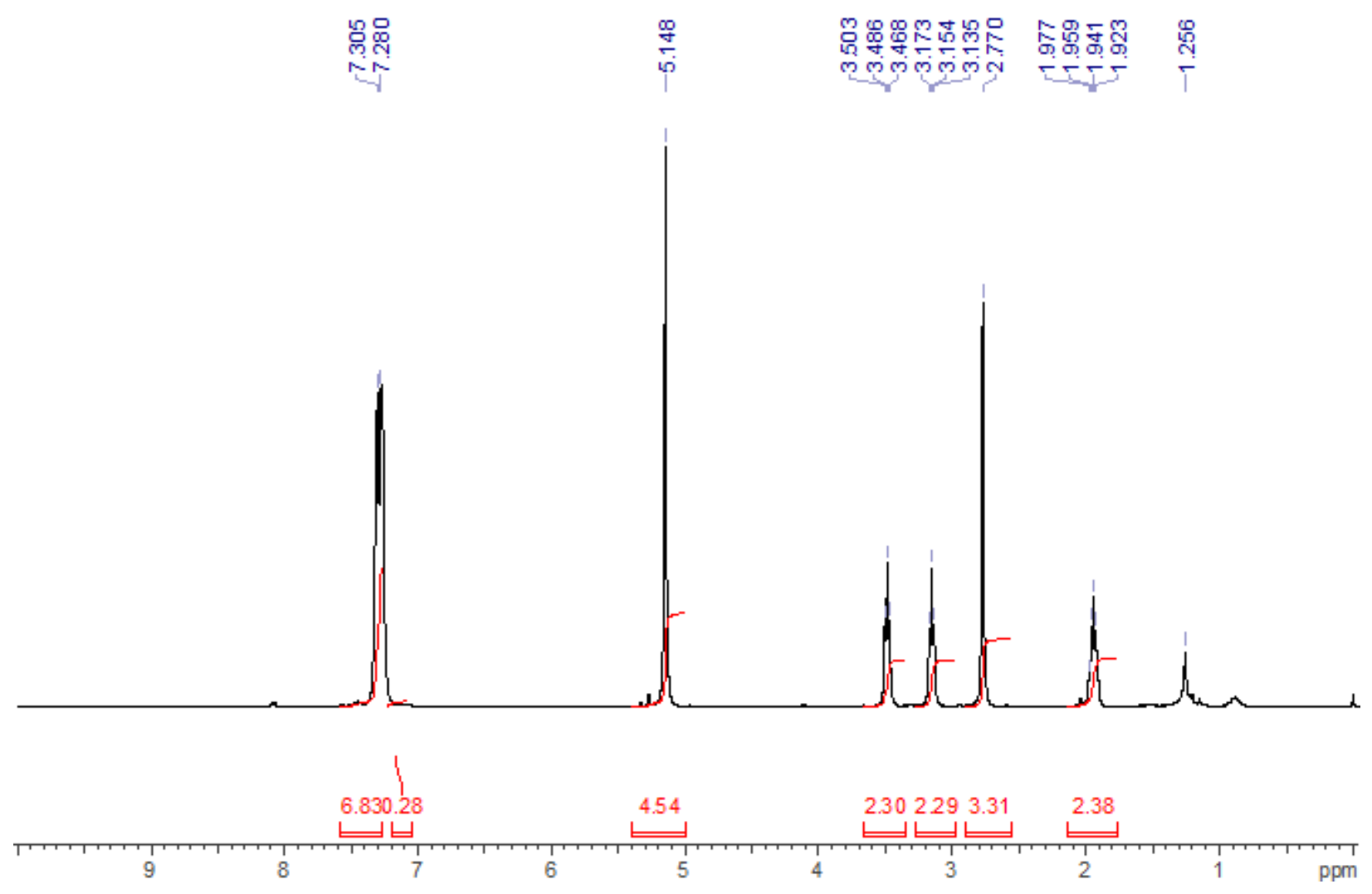


Figure S59. ${ }^{13} \mathrm{C}$ NMR of 8<smiles>CN1CCCC1=C(C(=O)OCc1ccccc1)C(=O)OCc1ccccc1</smiles>

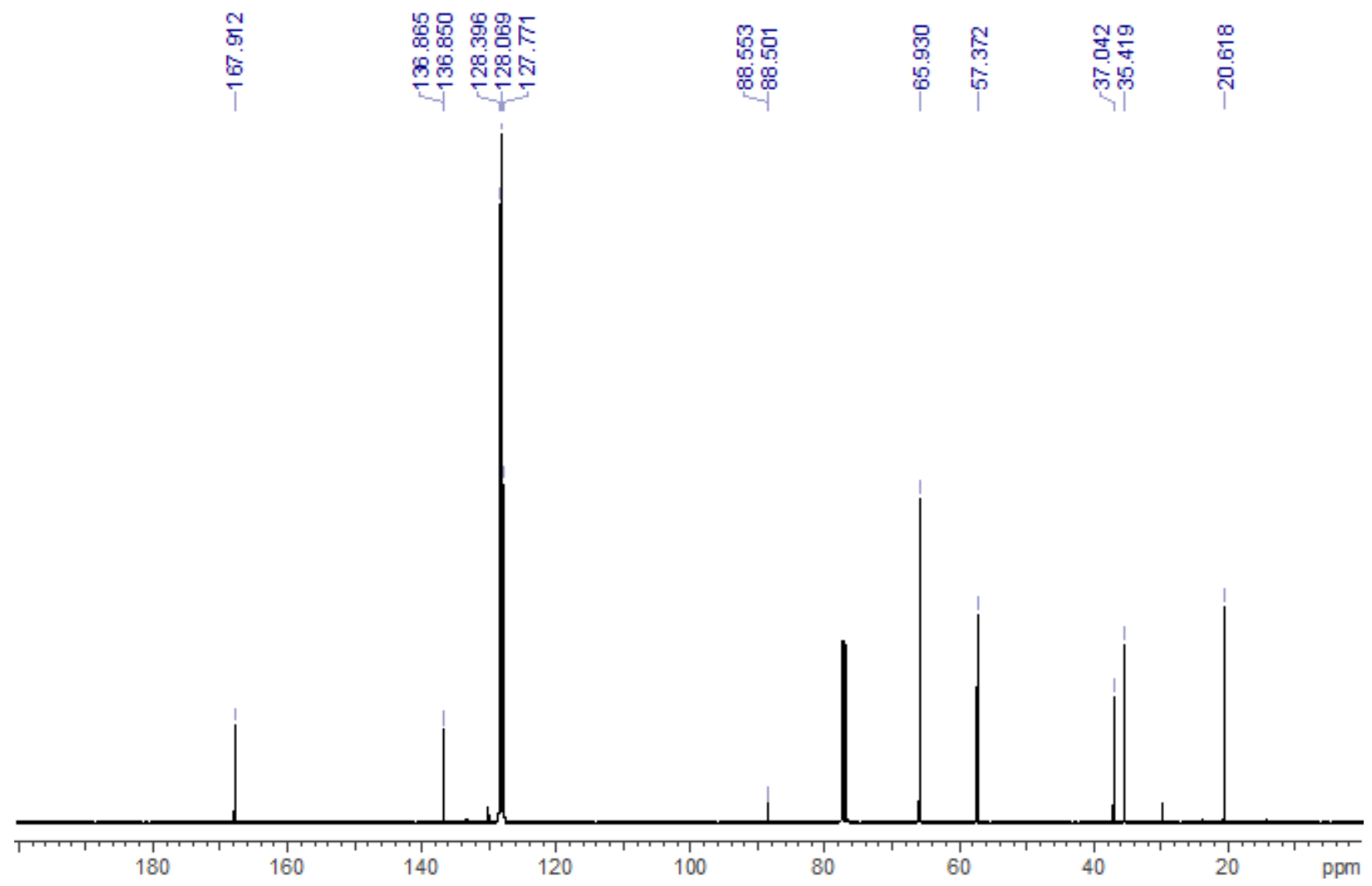


Figure S60. ${ }^{1} \mathrm{H}-{ }^{1} \mathrm{H}$ COSY spectrum of 8

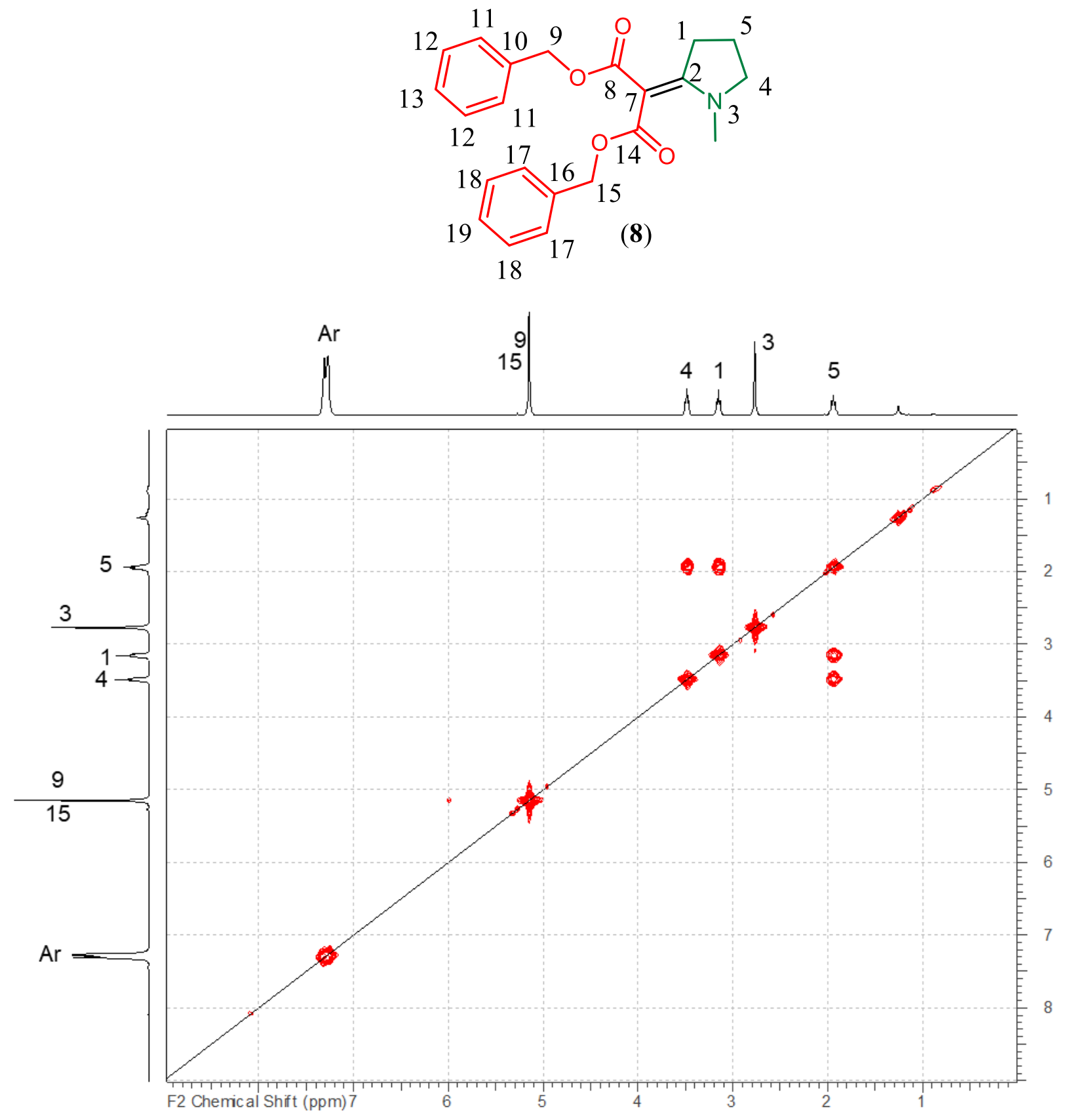


Figure S61. HSQC spectrum of 8
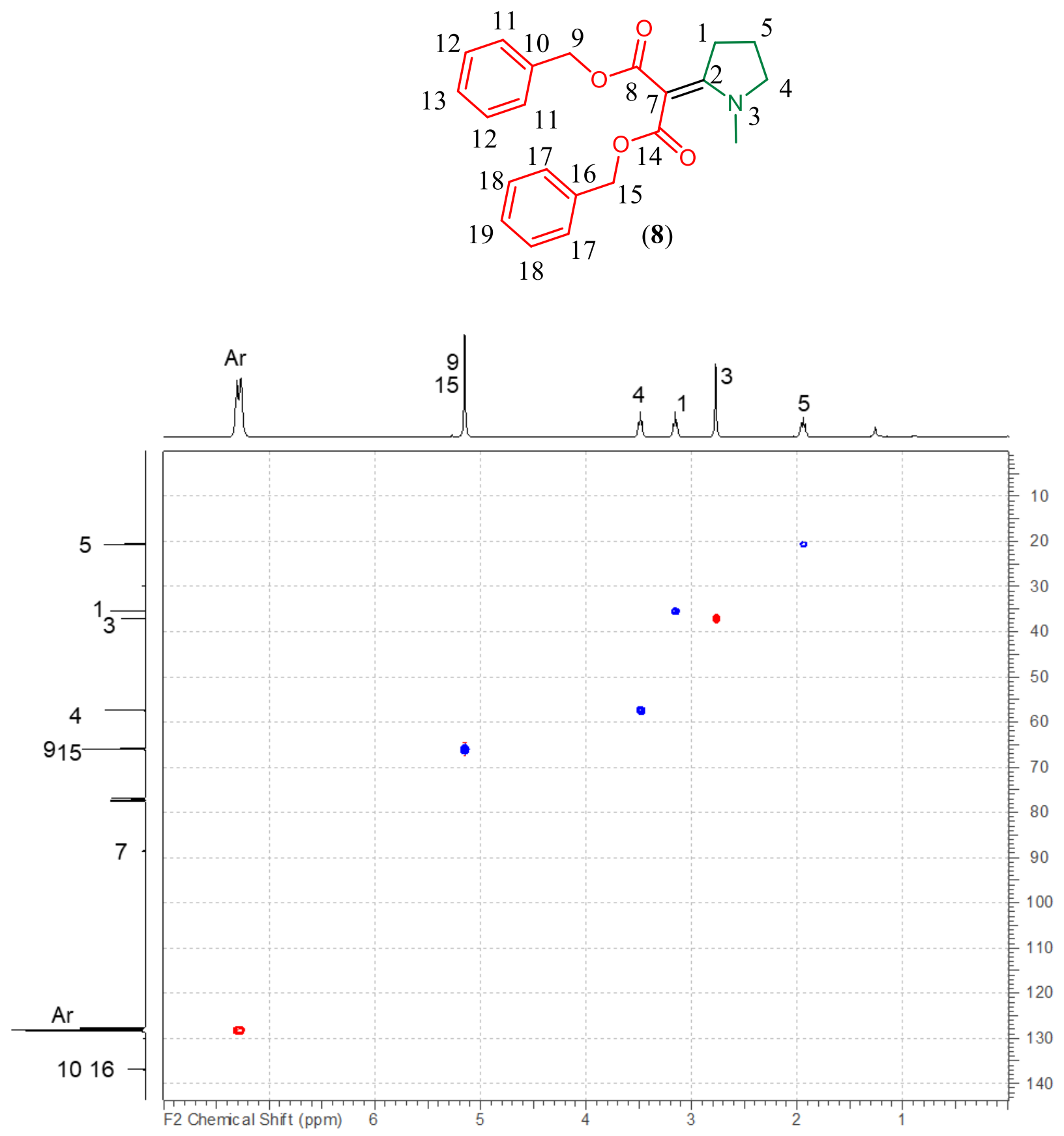
Figure S62. HMBC spectrum of 8
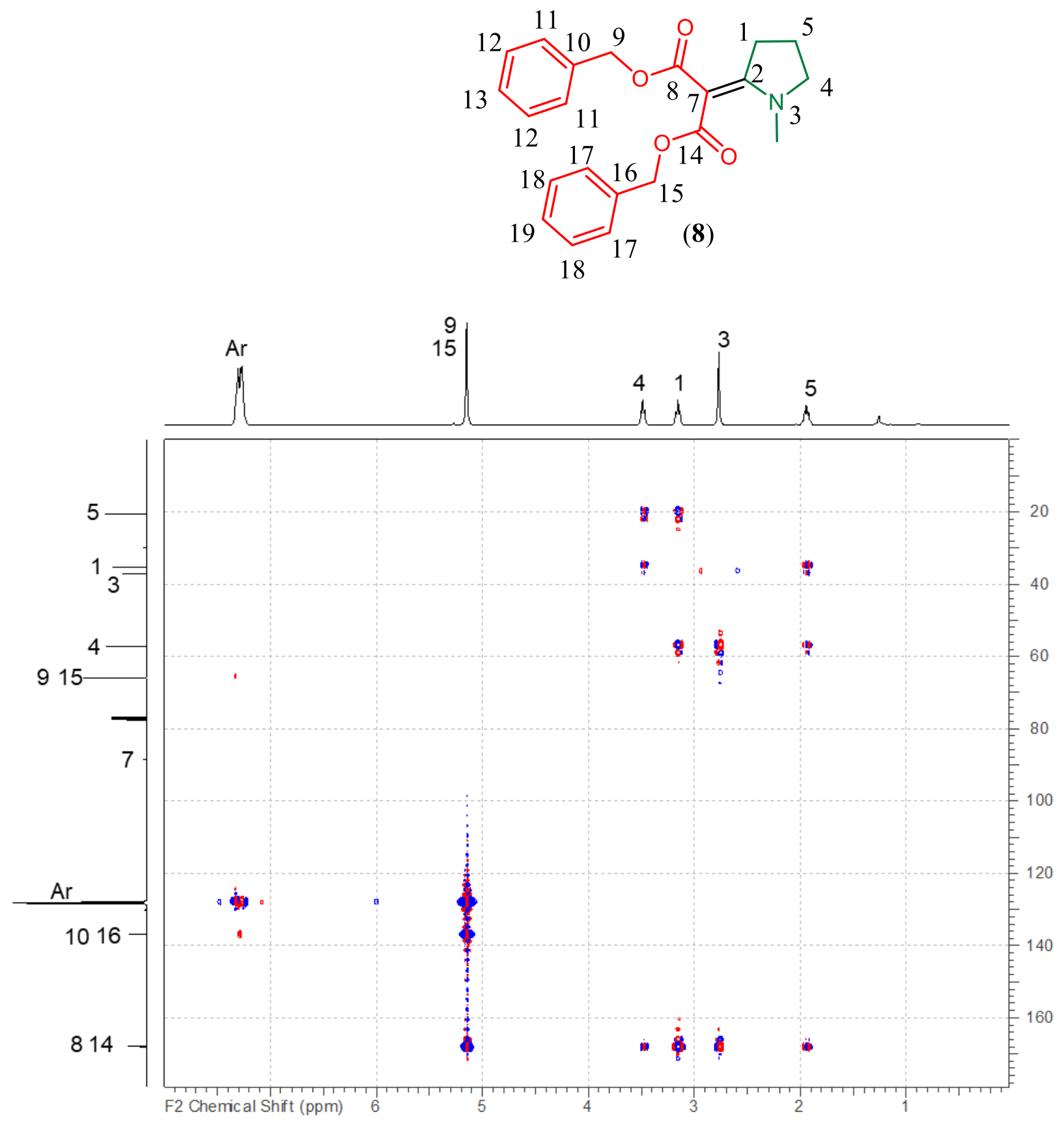
Figure S63. ${ }^{1} \mathrm{H}$ NMR spectrum of 9.
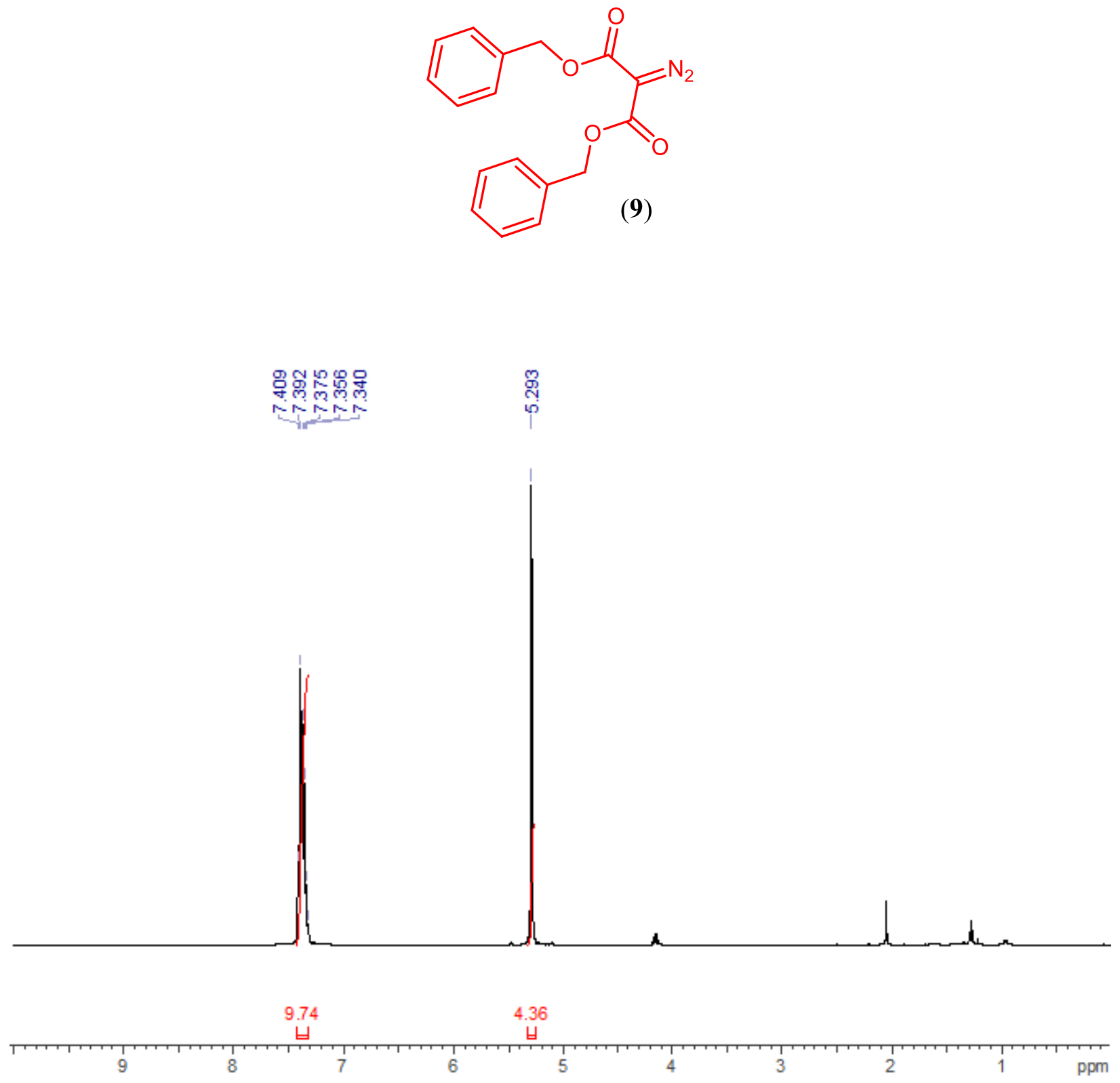
Figure S64. ${ }^{13} \mathrm{C}$ NMR spectrum of 9.

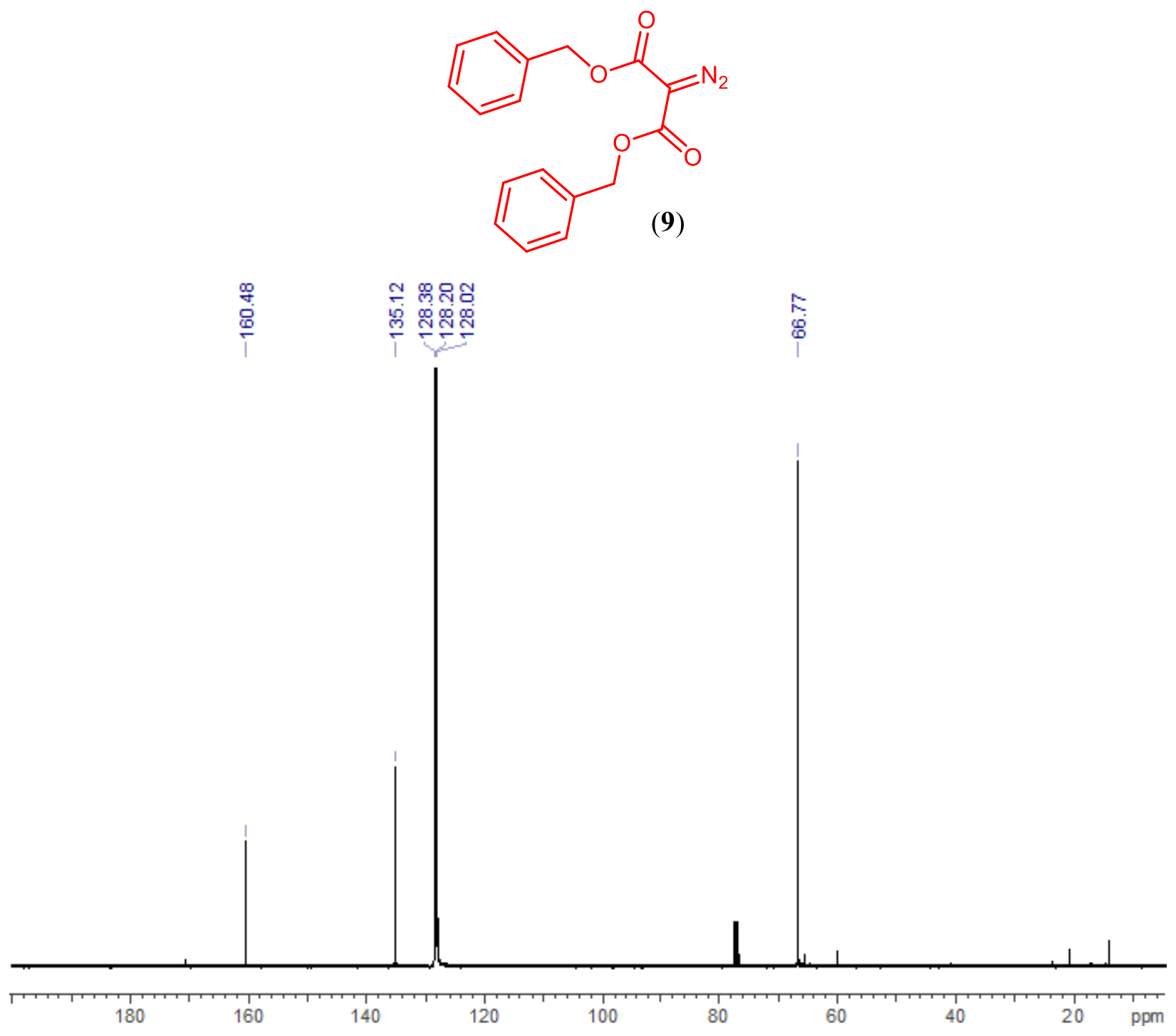




\section{References:}

1. Hussaini, S. R.; Chamala, R. R.; Wang, Z., The Eschenmoser sulfide contraction method and its application in the synthesis of natural products. Tetrahedron 2015, 71 (36), 6017-6086, http://dx.doi.org/10.1016/j.tet.2015.06.026.

2. Shvo, Y.; Shanan-Atidi, H., Internal rotation in olefins. I. Kinetic investigation by nuclear magnetic resonance. J. Am. Chem. Soc. 1969, 91 (24), 6683-6689, 10.1021/ja01052a025.

3. Kostyuchenko, N. P.; Granik, V. G.; Zhidkova, A. M.; Glushkov, R. G.; Sheinker, Y. N., Lactam acetals. Chem. Heterocyc. Compd. 1974, 10 (9), 1053-1059, 10.1007/BF00472121. 